UNIVERSIDADE DE BRASÍLIA

INSTITUTO DE CIÊNCIAS HUMANAS

DEPARTAMENTO DE GEOGRAFIA

PROGRAMA DE PÓS-GRADUAÇÃO EM GEOGRAFIA

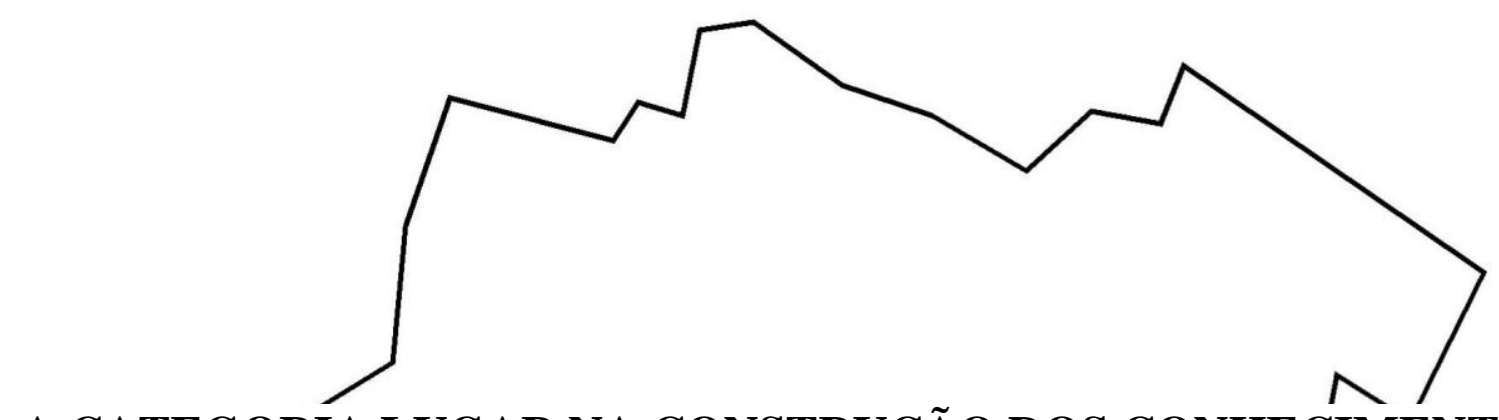

A CATEGORIA LUGAR NA CONSTRUÇÃO DOS CONHECIMENTOS GEOGRÁFICOS: ANÁLISE A PARTIR DA PRÁTICA PEDAGÓGICA DO PROFESSOR DE GEOGRAFIA EM FORMOSA-GOIÁS

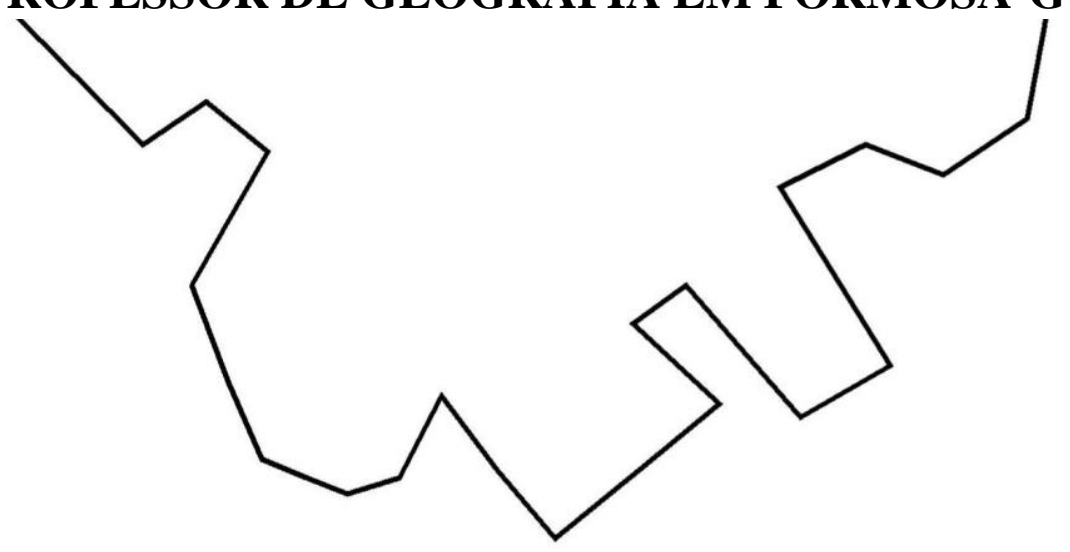




\title{
A CATEGORIA LUGAR NA CONSTRUÇÃO DOS CONHECIMENTOS GEOGRÁFICOS: ANÁLISE A PARTIR DA PRÁTICA PEDAGÓGICA DO PROFESSOR DE GEOGRAFIA EM FORMOSA-GOIÁS
}

\author{
Dissertação de Mestrado apresentada ao Programa de Pós- \\ Graduação em Geografia da Universidade de Brasília, como \\ parte dos requisitos necessários para obtenção do Grau de \\ Mestre em Geografia. \\ Área de concentração: Gestão Ambiental e Territorial \\ Linha de pesquisa: Produção do Espaço Urbano, Rural e \\ Regional \\ Eixo Temático: Formação Escolar Geográfica e Instrumentos \\ Educacionais \\ Orientadora: Prof ${ }^{\mathrm{a}}$. Dr ${ }^{\mathrm{a}}$. Cristina Maria Costa Leite
}


UNIVERSIDADE DE BRASÍLIA

INSTITUTO DE CIÊNCIAS HUMANAS

DEPARTAMENTO DE GEOGRAFIA

PROGRAMA DE PÓS-GRADUAÇÃO EM GEOGRAFIA

HUGO DE CARVALHO SOBRINHO

\title{
A CATEGORIA LUGAR NA CONSTRUÇÃO DOS CONHECIMENTOS GEOGRÁFICOS: ANÁLISE A PARTIR DA PRÁTICA PEDAGÓGICA DO PROFESSOR DE GEOGRAFIA EM FORMOSA-GOIÁS
}

\begin{abstract}
Dissertação de Mestrado apresentada ao Departamento de Geografia da Universidade de Brasília, como parte dos requisitos necessários para obtenção do Grau de Mestre em Geografia na área de concentração Gestão Ambiental e Territorial.
\end{abstract}

Aprovado em: I I

BANCA EXAMINADORA

Prof $^{a}$. Dr ${ }^{\mathrm{a}}$. Cristina Maria Costa Leite

Faculdade de Educação e Departamento de Geografia, Universidade de Brasília (Orientadora)

Prof $^{a}$. Dr ${ }^{a}$. Francilane Eulália de Souza

Departamento de Geografia, Universidade Estadual de Goiás, Câmpus Formosa

(Membro Externo)

Prof $^{a}$. Dr ${ }^{\mathrm{a}}$. Maria Fernanda Farah Cavaton

Faculdade de Educação, Universidade de Brasília

(Membro Interno)

Prof $^{\mathrm{a}}$. Dr ${ }^{\mathrm{a}}$. Antonia da Silva Samir Ribeiro

Secretaria de Estado de Educação do Distrito Federal

(Suplente)

Brasília, 08 de dezembro de 2016. 


\section{CARVALHO SOBRINHO, HUGO DE}

A categoria lugar na construção dos conhecimentos geográficos: análise a partir da prática pedagógica do professor de Geografia em Formosa - Goiás. / Hugo de Carvalho Sobrinho. Brasília-DF, 2016. 120 p.

Dissertação de Mestrado. Departamento de Geografia. Universidade de Brasília (UnB), Brasília - DF.

1. Lugar

3. Ensino-Aprendizagem

I. Universidade de Brasília, Departamento de Geografia II. Título

É concedida à Universidade de Brasília permissão para reproduzir cópias desta dissertação e emprestar ou vender tais cópias somente para propósitos acadêmicos e científicos. $\mathrm{O}$ autor reserva outros direitos de publicação e nenhuma parte desta dissertação de mestrado pode ser reproduzida sem a autorização por escrito do autor. 
Dedico este trabalho a todos os SECUNDARISTAS em luta em vários lugares do Brasil, de Goiás, de Formosa e do Distrito Federal, e em especial aos alunos que ocupam/ocuparam o Centro de Ensino Médio 01 - Planaltina/DF, no qual tive a honra de trabalhar no ano de 2015. A atitude de vocês é um orgulho para os professores da Educação Básica que buscam educar para a diversidade e criticidade. A escola é para vocês um espaço de sonhos, esperanças e laços afetivos, logo, lugar de referência. Acredito que as ações implementadas estão relacionadas a uma postura humanizante e libertadora que pensa $\mathrm{o}$ futuro de vocês e das novas gerações. Esse é o papel primordial da escola, educar para a cidadania, formar cidadãos que compreendam sua realidade e que possam participar de forma ativa, problematizadora e crítica nas transformações da sociedade. Obrigado por reconhecerem, desde cedo, o valor da luta contra a opressão! (01/11/2016) 


\section{AGRADECIMENTOS}

A realização de uma pesquisa em nível de mestrado acadêmico, como também, as demais atividades de ensino/aprendizagem que foram realizadas durante os anos de 2011 a 2016 (Graduação e Mestrado) fazem parte de uma ação coletiva e individual. A realização dessa tarefa resulta de um processo árduo, do qual hoje muito me orgulho, pois faz parte da busca por respostas as minhas próprias perguntas. Portanto, foram vários os sujeitos sociais que contribuíram para minha formação, sujeitos esses que possuem sentimento, razão e emoção. Agradeço imensamente à minha família - mãe, pai e irmãos -, que me amparam nas dificuldades, amo vocês de forma incondicional. Agradeço o acesso à escola pública durante toda a minha Educação Básica. Agradeço aos meus professores da Educação Básica, que me possibilitaram enxergar o mundo e o meu lugar de forma diferente. Aos meus professores da Universidade Estadual de Goiás (graduação) e Universidade de Brasília, especialmente à minha orientadora, por contribuir para a construção de uma identidade docente mais reflexiva e, além disso, ter contribuído para que eu possa ter uma visão mais apurada dos fenômenos geográficos por meio da categoria lugar. Agradeço aos professores que compuseram as bancas de qualificação e defesa deste trabalho, Prof $^{a}$. Dra . Francilane Eulália de Souza (UEG), Prof ${ }^{\mathrm{o}}$. $\operatorname{Dr}^{\mathrm{o}}$. Fernando Luiz Araujo Sobrinho (UnB), Prof ${ }^{\mathrm{a}} \mathrm{Dr}^{\mathrm{a}}$. Maria Fernanda Farah Cavaton (FE/UnB), Prof ${ }^{o}$. Dro ${ }^{\circ}$ Juscelino Eudâmidas Bezerra (UnB) e Prof ${ }^{a}$. Dr ${ }^{\mathrm{a}}$. Antonia da Silva Samir Ribeiro (SEDF), pelas contribuições valorosas neste trabalho. $\mathrm{Na}$ universidade, agradeço ao Grupo de Pesquisa Ensino, Aprendizagem e Formação de Professores em Geografia (GEAF), pelas conversas, desabafos e críticas à atual conjuntura que a educação pública, em geral, e o ensino de Geografia, em particular, se encontram. Aos meus amigos:

Rodrigo Suess, Rafael Bezerra, Sophia Lacerda, Rosinaldo Silva, Rafael Lima, Marcos Godoy, Gleiser Valério e Nayara Belle que estiveram presentes nesses entrelaços cotidianos e acadêmicos. À Coordenação de Aperfeiçoamento de Pessoal de Nível Superior (CAPES), pelo apoio financeiro. Devo meus sinceros agradecimentos aos professores das escolas públicas da cidade de Formosa - GO, onde realizei esta pesquisa.

Com carinho, Hugo de Carvalho Sobrinho 
Estudar e compreender o lugar em Geografia significa compreender o que acontece no espaço onde se vive para além de suas condições culturais e humanas. (...) permite ao sujeito conhecer sua própria história e conseguir entender as coisas que ali acontecem. Assim, ler o mundo a partir do lugar é um desafio. 


\section{RESUMO}

O lugar, categoria de análise do espaço geográfico, é um recurso fundamental da Geografia porque se apresenta como possibilidade de explorar os significados construídos pelos seres humanos, num dado local, e relacioná-los com a totalidade. No contexto educativo, ele constitui-se via de mediação pedagógica orientado à internalização de conhecimentos geográficos. Nesse sentido, esta investigação científica teve como objetivo examinar o processo de construção de conhecimentos geográficos por meio da categoria lugar na prática pedagógica do professor de Geografia. Considerando-se a cidade como espaço privilegiado, não único, da vida social e o lugar como uma construção humana, conjugam-se dois aspectos relevantes - cidade e lugar - a serem relacionados, tendo em vista a construção da aprendizagem do aluno, no campo disciplinar da Geografia. Assim, o município de Formosa/GO, limítrofe ao Distrito Federal, com seus festejos, manifestações culturais e religiosas, belezas naturais exuberantes, questões políticas, econômicas e o espaço social em geral, constitui-se um lugar ímpar ao contexto da escolarização, por ser o ambiente de vivência para os alunos dessa cidade. Com mais de 100.000 habitantes e 173 anos de história, apresenta problemas e situações típicas de uma cidade em desenvolvimento, logo, lugar que pode constituir como um alicerce para o entendimento dos conhecimentos geográficos trabalhados em sala de aula. A metodologia utilizada foi de base qualitativa, a partir dos seguintes procedimentos: pesquisa bibliográfica com o intuito de aprofundar o tema em questão; análise documental, mediante os documentos que regem o fazer pedagógico na escola, a saber: Projeto Político Pedagógico, Plano de Ensino e Livro Didático e entrevistas semiestrutradas com o intuito de conhecer o desenrolar das ações docentes. Percebeu-se, por meio das análises dos documentos e das entrevistas, que há muitos obstáculos a ser superados para que o ensino dessa disciplina se torne significativo, pois os resultados atestaram que o processo de aprender/ensinar Geografia, nas escolas pesquisadas, negligenciam a categoria lugar como instância mediadora na construção dos conhecimentos geográficos, o que interfere na formação para a cidadania. O Lugar/Formosa, mesmo constituindo-se como um espaço de vivências e experiências com os fenômenos geográficos, por ser o espaço vivido dos alunos dessa cidade, não é considerado nessa perspectiva. Portanto, espera-se que esta pesquisa possa contribuir para o desenvolvimento de outras, com a finalidade de reforçar a relevância do ensino de Geografia vinculado à realidade vivida pelo aluno. Trata-se de uma ação potencializadora, uma vez que, se o aluno compreende a sua Geografia, as demais Geografias serão construídas por um melhor entendimento do mundo, mais expressivo à formação do cidadão.

Palavras-chave: Lugar, Geografia, Ensino-Aprendizagem, Formosa-GO. 


\begin{abstract}
The place, a category of analysis of geographical space, is a Geographic's fundamental resource because it presents itself as a possibility to explore the meanings constructed by human beings, in a given place, and to relate them to the totality. In the educational context, it constitutes a means of pedagogical mediation oriented by the internalization of geographical knowledge. In this sense, this scientific investigation aimed to examine the construction process of geographical knowledge by the place category in the pedagogical practice of the Geography teacher. Considering the city as a privileged, but not unique, space of social life and place as a human construction, two relevant aspects - city and place - needs to be related, with a view to the construction of student's learning in the Geographic's Subject. Thus, the city Formosa/GO, bordering the Federal District, with its festivities, cultural and religious manifestations, exuberant natural beauties, political and economical issues and the social space in general, it's a unique place to the schooling's context, being the living environment for the students of this city. With more than 100,000 inhabitants and 173 years of history, has problems and typical situations of a developing city, therefore, a place that can constitute as a foundation for the understanding of the geographic knowledge taught in the classroom. The methodology used was qualitative, based on the following procedures: a bibliographical research with the intention of development the subject in question; Documentary analysis, from the documents that conducts the pedagogical practice in the school: the Political Pedagogical Project, the Teaching's Plan and the Didactic Book and structured interviews intentioned to know the evolution of the teaching actions. Through the analysis of the documents and the interviews, it was noticed that there are many obstacles to be overcome in order to make the teaching of this subject meaningful, since the results attest that the process of learning/teaching Geography in the schools surveyed neglects the Place category as mediator in the construction of geographical knowledge, which interferes with the citizenship's formation. The place/Formosa, even constituting itself as a space of experiences with the geographic phenomena, being the lived space of that city students, it's not considered in this perspective. Therefore, it's expected that this research may contribute to the development of others, to the relevance of Geographic teaching linked to the reality lived by the student. This is a potential action. If the student understands his Geography, the other Geographies will be constructed by a better world's understanding, more expressive to the citizen formation.
\end{abstract}

Keywords: Place, Geography, Teaching-learning, Formosa-GO. 


\section{RESUMÉ}

Le lieu, catégorie d'analyse de l'espace géographique, est un recours fondamental de la Géographie, parce qu'il se présente comme possibilité d'analyse des sens construits par les êtres humains dans un lieu déterminé, et de les met en relation avec la totalité. Dans le contexte éducatif, il se constitue par le biais d'une médiation pédagogique destinée à l'internalisation des savoirs géographiques. Dans cette optique, cette investigation scientifique a eu pour objectif d'analyser le processus de construction des savoirs géographiques au travers de la catégorie lieu dans la pratique pédagogique du professeur de Géographie. Considérant la ville comme espace privilégié non unique de la vie sociale, et le lieu comme une construction humaine, deux aspects importants qui se confondent, ville et lieu, doivent être mis en relation, ayant en vue la construction de l'apprentissage de l'élève dans le champ disciplinaire de la Géographie. Ainsi, la commune de Formosa/GO, limitrophe au District Fédéral, avec ses festivités, manifestations culturelles et religieuses, merveilles naturelles exubérantes, questions politiques et économiques et l'espace social en général, constitue un lieu propice au contexte de scolarisation, étant un environnement de vécu quotidien pour les élèves de cette ville. Avec plus de 100.000 habitants et 173 années d'histoire, la ville présente des problèmes et des situations typiques d'une ville en développement. De ce fait, le lieu peut représenter le fondement essentiel à la compréhension des savoirs géographiques vus en salle de cours. La méthodologie utilisée s'est faite qualitativement, suivant les procédures suivantes : recherche bibliographique dans l'intention d'approfondir le thème en question ; l'analyse documentaire à partir des documents qui régissent le faire pédagogique à l'école, à savoir : Projet Politique Pédagogique, Plan d'Enseignement et Livre Didactique et interviews semi-structurées, dans l'intention de connaître et dérouler les actions de l'enseignant. Il a été perçu par le biais des analyses des documents et des interviews qu'il y avait beaucoup d'obstacles à surmonter pour que l'enseignement de la discipline devienne significatif, car les résultats attestent que le processus de l'apprendre/enseigner la Géographie dans les écoles étudiées, négligeait la catégorie lieu comme instance médiatrice dans la construction des savoirs géographiques, ce qui interfère dans la formation de la citoyenneté. Le Lieu/Formosa, même en étant un espace de vécu et d'expérience des phénomènes géographiques, le cadre de vie des élèves de cette ville, n'est pas considéré dans cette perspective. Il est alors attendu que cette recherche puisse contribuer au développement d'autres, visant une accentuation de l'importance de l'enseignement d'une Géographie liée à la réalité de l'élève. On parle d'une action potentialisatrice. Une fois que l'élève comprend sa Géographie, les autres Géographies seront construites pour une meilleure compréhension d'un monde plus expressif à formation du citoyen.

Mots-clés: Lieu, Géographie, Enseignement-Apprentissage, Formosa-GO. 


\section{LISTA DE FIGURAS}

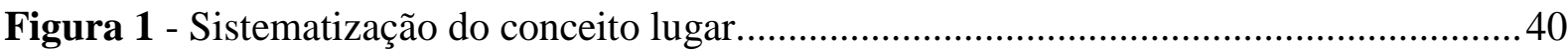

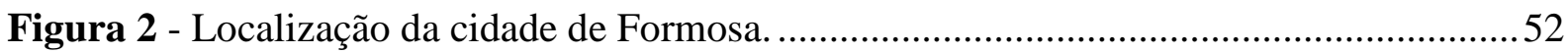

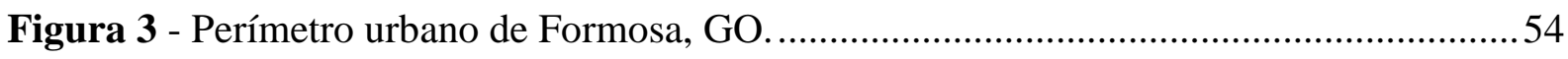

Figura 4 - Lugar/Formosa: exemplos de espaços conhecidos pelos alunos que podem ser convergidos ao processo de ensino/aprendizagem. .............................................................5

Figura 5 - Lugares de Formosa: (A) Lago do Vovô; (B) A Rua Visconde Porto Seguro, localizada na área central da cidade; (C) Museu Couros e (D) Casarão Antigo. ......................59

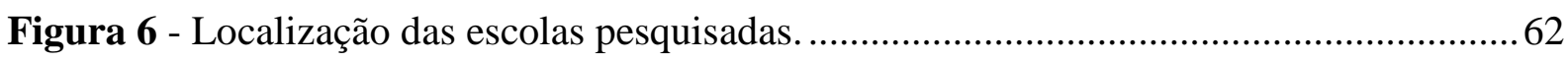

Figura 7 - Capa do livro Geografia do $9^{\circ}$ ano do Ensino Fundamental. ................................ 79 


\section{LISTA DE QUADROS}

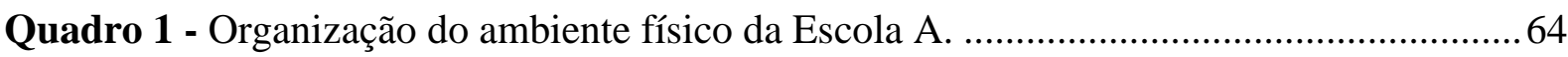

Quadro 2 - Organização do ambiente físico da Escola B.......................................................65

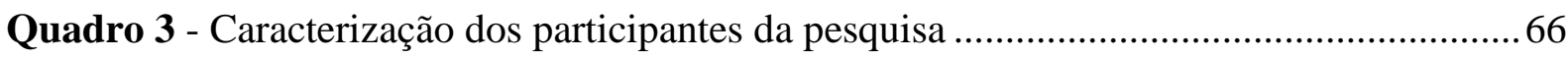

Quadro 4 - Projetos Políticos Pedagógicos das escolas pesquisadas. ..................................... 73

Quadro 5 - Plano de Ensino - relação entre conteúdo e utilização do lugar............................ 77

Quadro 6 - Organização dos conteúdos do Livro Didático do $9^{\circ}$ ano ..................................... 80

Quadro 7 - Síntese das respostas dos docentes - Primeiro encontro ........................................ 84

Quadro 8 - Síntese das respostas dos docentes - Segundo encontro ..................................... 87

Quadro 9 - Síntese das respostas dos docentes - Terceiro encontro ........................................94 


\section{LISTA DE ABREVIATURAS E SIGLAS}

APP - Áreas de Proteção Ambiental

CAPES - Coordenação de Aperfeiçoamento de Pessoal de Nível Superior

CME - Conselho Municipal de Educação

DF - Distrito Federal

EJA - Educação de Jovens e Adultos

ENANPEGE - Encontro Nacional da Associação Nacional de Pós-Graduação e Pesquisa em Geografia

GO - Goiás

IBGE - Instituto Brasileiro de Geografia e Estatística

IDH - Índice de Desenvolvimento Humano

IDHM - Índice de Desenvolvimento Humano Municipal

INEP - Instituto Nacional de Estudos e Pesquisas Educacionais Anísio Teixeira

LD - Livro didático

PCNs - Parâmetros Curriculares Nacionais

PE - Plano de Ensino

PIB - Produto Interno Bruto

PNLD - Plano Nacional do Livro Didático

PNUD-BRASIL- Programa das Nações Unidas para o Desenvolvimento no Brasil

PPP - Projeto Político Pedagógico

RIDE - Região de Desenvolvimento Integrado do Distrito Federal e Entorno

SME - Secretaria Municipal de Educação

UEG - Universidade Estadual de Goiás

UFU - Universidade Federal de Uberlândia

UNB - Universidade de Brasília

USP - Universidade de São Paulo 


\section{SUMÁRIO}

INTRODUÇÃ

1 GEOGRAFIA ESCOLAR E O LUGAR: CONSTRUÇÃO DE CONHECIMENTOS NO PROCESSO DE ENSINAR/APRENDER

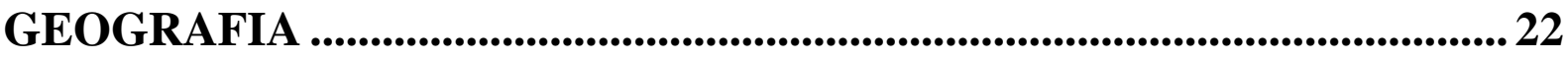

1.1 OS DESAFIOS E POSSIBILIDADES DE ANÁLISE DO ESPAÇO GEOGRÁFICO NO MUNDO GLOBALIZADO ................................................................................................................22

1.2 GEOGRAFIA ESCOLAR E SUA CONTRIBUIÇÃO AO PROCESSO DE CONSTRUÇÃO DA CIDADANIA: ALGUNS PRESSUPOSTOS.............................................27

1.3 ESPAÇO, LUGAR E ENSINO DE GEOGRAFIA: INTER-RELAÇÕES.............................35 1.4 CIDADE: VIVÊNCIA E EXPERIÊNCIA COM OS FENÔMENOS GEOGRÁFICOS ...42

\section{TRILHAS PERCORRIDAS: A CONSTRUÇÃO DE INFORMAÇÕES EMPÍRICAS

2.1 METODOLOGIA: A PESQUISA QUALITATIVA 49

2.2 O CONTEXTO DE CONSTRUÇÃO DE INFORMAÇÕES EMPÍRICAS 50

2.2.1 O município de Formosa/Goiás: breve explicitação desse lugar 50

2.2.2 As escolas alvos da pesquisa 60

2.2.2.1 Escola A: histórico, estrutura física e organizacional .......................................63

2.2.2.2 Escola B: histórico, estrutura física e organizacional ..........................................64

2.2.3 Os sujeitos da pesquisa: os professores de Geografia das escolas pesquisadas ..... 66

2.3 PROCEDIMENTOS PARA A CONSTRUÇÃO E ANÁLISE DAS INFORMAÇÕES EMPÍRICAS

2.3.1 Análise documental: PPPs, PE e LDs .......................................................67

2.3.2 Entrevistas semiestruturadas com os docentes pesquisados ................................69

2.3.3 Instrumentos e materiais ...........................................................................................71 
3 RESUlTAdos E DiscuSSÕeS: OBSTÁCULOS E PERSPECTIVAS PARA A CONSTRUÇÃO DOS CONHECIMENTOS GEOGRÁFICOS POR MEIO DA CATEGORIA LUGAR ................................................... 72

3.1 RESULTADOS E DISCUSSÕES...............................................................................72

3.1.1 Análise documental ..................................................................................................................... 72

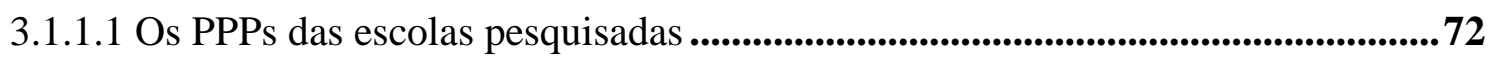

3.1.1.2 Plano de Ensino de Geografia .........................................................................76

3.1.1.3 O livro didático utilizado .....................................................................................................78

3.1.2 Os professores e o Lugar/Formosa no processo de ensinar/aprender Geografia:

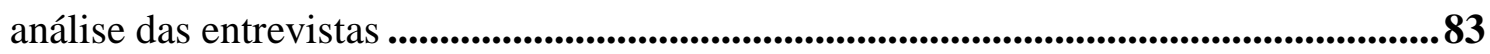

3.1.2.1 Sistematização e análise dos quadros sínteses das entrevistas ............................83

CONSIDERAÇÕES FINAIS ....................................................................................... 103

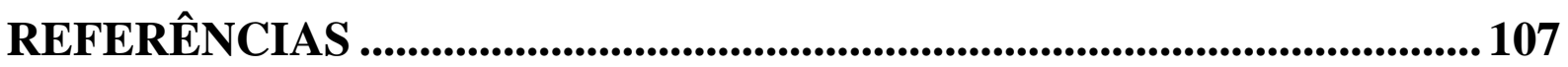

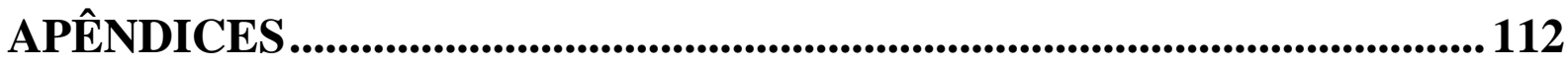

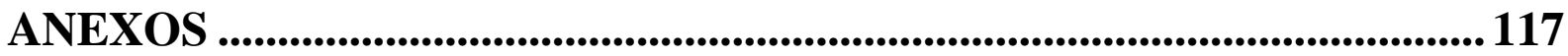




\section{APRESENTAÇÃO}

Muitas vezes sabemos coisas do mundo, admiramos paisagens maravilhosas, nos deslumbramos por cidades distantes, temos informações de acontecimentos exóticos ou interessantes de vários lugares que nos impressionam, mas não sabemos o que existe e o que está acontecendo no lugar em que vivemos. (...) O lugar está presente de diversas formas. Estudálo é fundamental, pois, ao mesmo tempo em que o mundo é global, as coisas da vida e as relações sociais se concretizam nos lugares específicos (CALLAI, 2000, p. 71).

Ao escolher como elemento inspirador e instigador a epígrafe acima, trago à tona, mais uma vez, as reflexões que permeiam a discussão de tantos geógrafos e professores dedicados à educação geográfica. Tais reflexões apontam para a relevância da prática pedagógica em Geografia, mediante valorização do lugar para a construção de conhecimentos geográficos.

Este trabalho começou a ser pensado no curso de graduação em Geografia na Universidade Estadual de Goiás (UEG), Câmpus Formosa, quando me foi apresentado o texto Estudar o lugar para compreender o mundo, escrito pela professora Helena Copetti Callai. Por meio da leitura, comecei meus questionamentos sobre a educação geográfica. Esse exercício foi um estímulo inicial para o desenvolvimento de alguns trabalhos concernentes à temática, que permeia minha formação.

Outro fato interessante me instigou. Quando comecei a desenvolver o trabalho de conclusão de curso da graduação, voltado para análise da utilização da categoria lugar nos livros didáticos de Geografia do $6^{\circ}$ ano do Ensino Fundamental, tive uma rica conversa com a professora de uma das escolas que pesquisei. A docente me questionou acerca da questão da utilização do lugar do aluno, para pensar a Geografia: "Hugo, você que vem fazendo leituras sobre a didática em Geografia, responda-me uma coisa: que possibilidades temos para trabalhar o lugar e, por meio dele, desenvolver os diversos conteúdos presentes no currículo de Geografia?". Não lembro exatamente o que respondi, mas a partir daquele momento percebi que a problemática levantada pela professora foi ao encontro de minhas reflexões, realizada nos trabalhos desenvolvidos ao longo da graduação e corroborou, também, com as de muitos professores de Geografia (CALLAI, 2000; CASTELLAR, 2010; CAVALCANTI, 2002, 2012; LEITE, 2012; STRAFORINI, 2008). Assim sendo, decidi investigar a questão 
com mais profundidade, assumindo-a como problema de pesquisa a ser analisado em nível de Mestrado. Nesse sentido, defende-se que o lugar e o cotidiano do aluno não devem ser menosprezados, mas sim utilizados como possibilidade e ponto de partida e chegada no ensino de Geografia. Além disso, assume-se neste trabalho o lugar como ponto de ligação das dimensões do local, regional, nacional e global (SANTOS, 2009), numa abordagem que considera a perspectiva da totalidade. Portanto, com a dinâmica das transformações que caracterizam o mundo contemporâneo, o ensino de Geografia deve orientar-se pelo lugar e pela cotidianidade dos alunos, para conferir significados aos conhecimentos geográficos construídos em sala de aula.

Ao assumir esta perspectiva, pretende-se reforçar a relevância do ensino em Geografia no período atual vinculado à realidade vivida pelo aluno. Certamente, a opção de destacar essa temática vincula-se à busca por possibilidades e proposições metodológicas mais significativas no processo de ensinar/aprender Geografia. 


\section{INTRODUÇÃO}

As transformações que ocorrem no mundo contemporâneo se apresentam cada vez mais dinâmicas e isso tem desencadeado questionamentos em âmbito educativo. Nesse sentido, e de acordo com Santos (2009), diante das transformações impostas pela introdução de novas técnicas nas relações estabelecidas pelos vários sujeitos de uma sociedade e, também, pelo processo de globalização da economia, a ciência geográfica vem efetuando análises que permitem compreender e interpretar essa realidade, para fomentar o processo de intervenção na construção do espaço. Considerando-se que o mundo tem mudado rapidamente, pode-se deduzir que se torna mais difícil compreendê-lo, em virtude das velocidades com que ocorrem as mudanças. Nesse contexto, a educação em geral e a escola, em particular, assumem um papel relevante à compreensão da realidade. Desse modo, se pretendemos que as práticas pedagógicas em Geografia sejam adequadas à compreensão da contemporaneidade, devemos considerar a dinâmica espacial, que evidencia a alteração das formas e funções postas no cotidiano vivido pelo indivíduo.

Como ciência, a Geografia dispõe de aporte teórico e conceitual que possibilita a análise de fenômenos espaciais em distintas perspectivas, por meio das categorias de análise do espaço geográfico. Entre essas categorias, destaca-se o lugar, que permite, por seu intermédio, que outras categorias sejam consideradas, como por exemplo: paisagem, território, região e espaço. Ele se constitui um recurso à compreensão da espacialidade, no sentido de viabilizar a construção de significados vividos por uma dada comunidade, num dado local, passíveis de replicação para compreensão da própria totalidade e, por conseguinte, da compreensão do processo de produção e reprodução do próprio espaço.

Na educação em geral, e na Geografia em particular, a utilização da categoria lugar como via de mediação pedagógica para a internalização dos conhecimentos geográficos, tem suscitado reflexões. Nesse sentido, vários pesquisadores analisaram a temática e a consideraram referência ao processo de ensinar/aprender (CALLAI, 2000; CASTELLAR, 2010; CAVALCANTI, 2002, 2008, 2012; LEITE 2012; STRAFORINI, 2008). Tais análises atestam que é possível atribuir significados aos conteúdos de Geografia, por meio da identificação e análise dos fenômenos experimentados no cotidiano vivido dos alunos e sua posterior relação com outros contextos, em outras escalas. 
Assim, o lugar deve ser uma referência constante, mediando o processo de aprenderensinar, considerando o aluno como sujeito ativo (CAVALCANTI, 2012). A escola, nessa perspectiva, constitui-se local de troca de experiências vividas e, por isso, um espaço privilegiado na sociedade contemporânea. Nela a realidade precisa ser associada às disciplinas escolares, para que os educandos possam aprender conteúdos diversos: de um lado, valores éticos e morais, com a finalidade de contribuir nas relações humanas postas no cotidiano; de outro, construção de saberes significativos, oriundos das disciplinas escolares formalmente estruturadas, que objetivem a formação de cidadãos, que possam compreender, intervir e reconstruir a sociedade em que vivem. Tal intento será possível, acreditamos, se o lugar onde está a escola, seus alunos e professores, for considerado nas reflexões que impliquem na compreensão da realidade.

A escola como uma instituição social pode preparar o aluno para ler e reler, de forma crítica e reflexiva, o seu lugar. Em consequência, pensar o mundo a partir do seu cotidiano e saber relacioná-lo ao contexto global. De um modo geral podemos afirmar que todas as disciplinas escolares dispõem da possibilidade de uso do conceito lugar, para conferir significação aos conhecimentos. A Geografia, em particular, pois o lugar constitui-se via de compreensão para noções abstratas como, por exemplo, a organização espacial. Desse modo, o lugar, como categoria de análise do espaço geográfico, se apresenta como instrumento capaz de subsidiar a construção dos conhecimentos geográficos, que fazem parte do cotidiano vivido pelo aluno, e a partir daí, sua inter-relação com outros conhecimentos associados às dimensões econômicas, políticas e culturais, em distintas escalas, que contribuem para explicar o processo de produção do espaço em diferentes partes do mundo.

Considerando-se que o conceito organização espacial é de difícil compreensão às crianças e jovens estudantes do Ensino Fundamental, por ser complexo e abstrato, torna-se importante utilizar, no processo de mediação pedagógica, algumas situações presentes e/ou vivenciadas no cotidiano do aluno, para que ele disponha de elementos mais concretos ao estabelecimento de parâmetros de comparação, que lhe permitam compreender aquela abstração. Ou seja, parte-se do mundo vivido pelo aluno para chegar à sistematização de ideias, que permitam a construção do saber geográfico. Tal situação reitera a importância da Geografia Escolar, pautada pela perspectiva de valorização do lugar. Entretanto, essa abordagem ainda carece de reflexões que possam permitir a proposição e implementação de formas de condução do processo de ensino/aprendizagem, que resulte em uma formação 
adequada às exigências e posturas do mundo contemporâneo e à formação da cidadania, de um lado, e a produção de conhecimento científico, de outro.

A consideração do lugar associa-se ao conceito de urbano e rural e, em consequência, ao conceito de cidade e campo. Assim, o lugar viabiliza o entendimento que a cidade e o campo constituem-se uma construção social. Ambas as perspectivas revelam as contradições postas no mundo vivido das pessoas, as quais devem ser consideradas no processo de construção de significados, que possibilitem a leitura do mundo, apontada como uma das funções do ensino de Geografia na escola básica. Desse modo, este estudo terá como foco destacar a cidade como possibilidade ao estudo do lugar, pois é um dos lugares imediatos (não o único) das relações humanas, que deve ser valorizado na construção de significados no ensino de Geografia.

O estudo do lugar se apresenta como uma possibilidade de compreensão do mundo contemporâneo, dos conhecimentos a ele vinculados e, nesse contexto, um desafio para as aulas de Geografia. Entende-se que a cidade está inserida na compreensão do lugar, pois os fenômenos que aí ocorrem, ampliam a capacidade dos alunos de compreender o mundo vivido de forma mais sistematizada e, quando não vivido, constituem-se parâmetros de comparação. Ao propor o estudo do lugar para a construção de conhecimentos no processo de ensinar/aprender Geografia deve-se considerar a cidade como um lugar de vivência e experiências.

Nesse contexto, a cidade de Formosa/GO, limítrofe ao Distrito Federal, com suas festas, festejos, manifestações culturais e religiosas, belezas naturais exuberantes, constitui-se um lugar ímpar ao processo de escolarização, por ser um espaço vivido e conhecido aos alunos dessa cidade. Com mais de 100.000 habitantes e 173 anos de história, apresenta problemas e situações típicas de uma cidade em desenvolvimento. Logo, é um lugar da vida que pode ser utilizado para instrumentalizar o processo de significação e a construção dos conhecimentos científicos trabalhados em sala de aula.

Tal situação imputa o estabelecimento de condições de cooperação entre os alunos, que devem ser fomentadas, no sentido de propiciar relações entre seu saber cotidiano e o saber sistematicamente elaborado, discutido no âmbito escolar. Desse modo, e a partir dessas relações, pretende-se que os alunos possam refletir, questionar, debater e elaborar proposições a respeito das situações identificadas em seu espaço geográfico. Importante ressaltar, que as 
questões culturais, sociais, econômicas, políticas, étnicas e religiosas, que compõem a prática social dos alunos, apresentam-se como possibilidade concreta de aprendizagem do próprio processo de produção do espaço, inclusive para além do lugar. Nesse caso, a cidade de Formosa/GO foi escolhida como lugar, nesta investigação, por fazer parte do cotidiano e da vivência do pesquisador.

Assim, esta pesquisa pretende contribuir com os debates acerca da Geografia Escolar, notadamente em relação à constituição de significados sobre a cidade, por meio da categoria lugar, tendo em vista sua importância na compreensão da realidade social, pois o lugar é um centro de significados construídos pela experiência (TUAN, 2011). Nesse contexto se estabelecem as questões que orientarão essa pesquisa, a saber: Quais as possibilidades do lugar contribuir para a significação dos conteúdos de Geografia? Como o ensino da Geografia, por meio do lugar, pode contribuir na mediação da formação de cidadãos? No Lugar/Formosa há possibilidades de construção de significados dos conteúdos trabalhados pelos professores? Os professores compreendem que o lugar está inserido na compreensão da cidade?

É a partir dessas indagações que se delineia o objetivo geral desta pesquisa, que é:

- Analisar o processo de construção de conhecimentos geográficos por meio da categoria lugar na prática pedagógica do professor de Geografia.

Como objetivos específicos podem ser elencados:

- Identificar e analisar como o lugar se constitui via de mediação pedagógica;

- Verificar e analisar como o Lugar/Formosa é considerado nos PPPs das escolas;

- Identificar e analisar como os Planos de Ensino utilizam o Lugar/Formosa;

- Analisar a abordagem do lugar no Livro Didático utilizado;

- Averiguar e analisar se/como o professor utiliza o Lugar/Formosa no processo de construção de conhecimentos geográficos.

Dessa forma, a suposição que norteou essa investigação é que o professor não utiliza o Lugar/Formosa no processo de mediação pedagógica orientado à construção dos conhecimentos científicos em Geografia. 
Como o objeto de estudo está relacionado à prática pedagógica em Geografia, fica evidente a relevância de mecanismos para a construção de informações empíricas. Portanto, para atingir os objetivos deste trabalho, a metodologia, de base qualitativa, prevê os seguintes procedimentos: análise documental dos Projetos Políticos Pedagógicos (PPPs), Planos de Ensino (PE) e Livro Didático (LD) e entrevistas semiestruturadas com professores das escolas pesquisadas. A pesquisa empírica foi realizada durante os meses de Maio, Julho e Agosto de 2016, contando com a identificação e seleção dos documentos para análise e entrevistas com os professores.

Por fim, cumpre enunciar, que o presente texto contempla três capítulos. No primeiro se explicita a fundamentação teórica desta pesquisa, denominada: “A Geografia Escolar e o lugar: construção de conhecimentos no processo de ensinar/aprender Geografia”. Esse item apresenta considerações acerca dos desafios e possibilidades de análises do espaço geográfico no mundo globalizado; ensino de Geografia e sua relação com a construção da noção de cidadania; análise da relação entre espaço, lugar e ensino de Geografia; análise da cidade e suas relações com a vivência e experiência dos alunos, relacionadas aos fenômenos geográficos do município de Formosa.

O segundo capítulo refere-se à metodologia. Denominado "Trilhas percorridas: a construção de informações empíricas" explicita o método para alcance dos objetivos de pesquisa propostos. Nesse sentido, apresenta-se o contexto de construção das informações empíricas, onde são apresentadas as características gerais do município de Formosa/GO, as escolas alvos da pesquisa, a caracterização dos professores participantes. Além disso, serão especificados os procedimentos de construção das informações empíricas, bem como os critérios para sua análise, a saber: análise documental e entrevistas.

O terceiro capítulo apresenta os resultados e discussões desta pesquisa. Denominado "Resultados e discussões: obstáculos e perspectivas para a construção dos conhecimentos geográficos por meio da categoria lugar", se apresentam divididos em dois momentos: análise documental e entrevistas. Os resultados foram apresentados por meio de quadros que sistematizam as informações empíricas construídas. É importante esclarecer que toda sistematização das informações foram efetuadas tendo como foco a categoria lugar na construção da aprendizagem em Geografia. Os documentos analisados e as falas dos professores expressaram desafios que influem na prática pedagógica e, consequentemente, 
impossibilita uma visão e utilização da categoria lugar na mediação dos conhecimentos geográficos. 


\section{GEOGRAFIA ESCOLAR E O LUGAR: CONSTRUÇÃO DE CONHECIMENTOS NO PROCESSO DE ENSINAR/APRENDER GEOGRAFIA}

Esta pesquisa integra o processo complexo de reflexão sobre o ensino de Geografia nos anos finais do Ensino Fundamental. Nesse sentido, Cavalcanti (2012) reverbera que, infelizmente, o ensino dessa disciplina ainda está atrelado a uma metodologia tradicional. Em consequência, inadequada às exigências do mundo atual, que demanda compreensão efetiva das questões que se põem no cotidiano local e global, uma leitura crítica dessas e, principalmente, uma capacidade criativa em termos de proposições a serem desenvolvidas, para dar conta da multiplicidade de situações, que se impõem ao cidadão comum, no contexto de sua coletividade.

Este capítulo está dividido em quatro momentos inter-relacionados. O primeiro - Os desafios e possibilidades de análise do espaço geográfico no mundo globalizado - apresentase a visão do mundo decorrente do processo de globalização da economia e os desafios que se originam a partir dessa situação. No segundo momento - Geografia escolar e sua contribuição ao processo de construção da cidadania: alguns pressupostos - são tecidas considerações acerca da importância do ensino de Geografia para a construção da noção de cidadania. No terceiro, - Espaço, lugar e ensino de Geografia: inter-relações - são analisadas a inter-relação entre espaço, lugar e ensino de Geografia. Por fim, - Cidade: vivência e experiência com os fenômenos geográficos - estabelecemos uma relação entre Geografia, cidade e lugar, no sentido de identificar e analisar como essa relação contribui para a construção de conhecimentos no processo de ensinar/aprender Geografia.

\subsection{OS DESAFIOS E POSSIBILIDADES DE ANÁLISE DO ESPAÇO GEOGRÁFICO NO MUNDO GLOBALIZADO}

O espaço é dinâmico e possui passado, presente e futuro. Por conseguinte, a análise da contemporaneidade se revela complexa, na medida em que tais instâncias temporais se articulam para explicar a própria espacialidade. 
A explicação dessa realidade contemporânea é marcada por um movimento acelerado da modernidade estabelecida pelas novas condições de transformação, ocasionado pelas tecnologias mais sofisticadas e pelas novas formas de comunicação. As mercadorias seduzem as sociedades e origina o consumo de forma demasiada. Essa sedução acaba por impulsionar as forças produtivas e esse fascínio conduz uma alienação, pois as pessoas acabam por perder os seus referenciais (GIDDENS, 1991; DEBORD, 1997; HARVEY, 1992).

Atrelado a isso, a história evidencia essa complexidade na transição do final do século XX e o início do século XXI, quando se nota um período que foi marcante pelo desenvolvimento da sociedade, principalmente, a ocidental contemporânea. Essa situação permitiu uma diversidade de processos, que alteraram o padrão de acumulação através da tecnologia e, por meio dela, transformou, radicalmente, as formas de relacionamento e interações humanas e, por conseguinte, conduziu a pensar sobre as novas formas das relações de ensino-aprendizagem (LEITE; BARBATO, 2011).

Ao considerar essa complexidade, deve-se analisar a dinamicidade do espaço, significativa expressão da contemporaneidade:

\begin{abstract}
Complexidade talvez seja a característica mais marcante da contemporaneidade, pois o mundo em que vivemos, articula uma multiplicidade de facetas, que desestrutura o indivíduo e as relações societais. A contradição é a via de relação entre as partes que compõem o todo. Não existem mais verdades absolutas e os pontos de vista são direcionados pelo relativo: à cultura, sob a ótica de um dado lugar, na perspectiva de um específico grupo social, na lógica da estrutura econômica, no prisma do poder político (LEITE; BARBATO, 2011, p. 231).
\end{abstract}

Dessa forma, vivemos em um momento histórico impregnado por mudanças estruturais, onde se destacam as perspectivas culturais, sociais, políticas e econômicas. Tais mudanças são, sobretudo, decorrentes do processo de globalização da economia, que em virtude da incorporação da tecnologia no contexto de articulação e interação entre pessoas/países, acelera e diferencia tempos e espaços. Entre tantas transformações destacamse aquelas novas relações, que são estabelecidas no espaço, por meio da mistura das culturas, que resultam em novas formas de expressão.

A globalização é uma das características principais do período atual, por abarcar boa parcela do mundo (SANTOS, 2009). Nesse sentido, é por meio da ciência, da técnica e da 
informação que a humanidade se debruça sobre fenômenos, sociais, políticos e econômicos nunca antes vistos na sua história. Esse processo unificador está intimamente relacionado ao sistema capitalista que visa à busca avassaladora do lucro. Desse modo é necessário compreender que:

A globalização é, de certa forma, o ápice do processo de internacionalização do mundo capitalista. Para entendê-la, como, de resto, a qualquer fase da história, há dois elementos fundamentais a levar em conta: o estado das técnicas e o estado da política. Há uma tendência a separar uma coisa da outra. Daí muitas interpretações da história a partir das técnicas. E, por outro lado, interpretações da história a partir da política. Na realidade, nunca houve na história humana separação entre as duas coisas. As técnicas são oferecidas como um sistema e realizadas combinadamente através do trabalho e das formas de escolha dos momentos e dos lugares de seu uso. É isso que fez a história (SANTOS, 2009, p. 23).

Isso significa que a globalização se apresenta como um processo complexo e desigual, por estar relacionado à lucratividade. Por conseguinte, os campos cultural, tecnológico, social, econômico, entre outros, são afetados nessa perspectiva homogeinizadora, onde convergem em distintas dinâmicas e resultam em espaços integradores (CAVALCANTI, 2008).

Importante ressaltar, nessa conjuntura, que as transformações provocadas pelo processo de globalização se materializam no lugar, isto é, ele se apresenta como o ponto de manifestação concreta desse processo.

A globalização materializa-se concretamente no lugar, aqui se lê/percebe/entende o mundo moderno em suas múltiplas dimensões, numa perspectiva mais ampla, o que significa dizer que no lugar se vive, se realiza o cotidiano e é aí que ganha expressão o mundial. O mundial que existe no local, redefine seu conteúdo, sem, todavia anularem- se as particularidades. (CARLOS, 2007, p.14).

Assim, é possível, compreender as relações local/global por meio do que nos é transmitido por vias tecnológicas de forma instantânea, simultânea e assíncrona (LEITE, 2012). Tal possibilidade constitui-se significativa, pois leva a perceber a diversidade de formas e conteúdos das cotidianidades vividas, que extrapolam e dão peculiaridades aos lugares. Em contraposição, o modo utilizado pelo sistema capitalista conduz à homogeneização cultural, isto é, padronização de gostos, hábitos, consumo, lazer etc. A esse respeito Cavalcanti (2008) destaca, 
$\mathrm{O}$ advento das tecnologias leva as pessoas a vivenciarem o mundo de modo mais próximo, provocando familiaridades antes impossíveis entre determinados lugares e suas representações pelos meios de comunicação; com essas tecnologias também é possível impor estilos de vida internacionais, globais, por meio da adesão, por cidadãos do mundo inteiro, ao consumo de alguns produtos e serviços (p. 16).

Dessa maneira, a globalização adquire um novo status, no período atual, que se diferencia drasticamente dos demais períodos, pois a técnica, a informação e a ciência condicionam a ligação entre todo o mundo, mesmo que de forma contraditória (SANTOS, 2009).

Essa realidade dinâmica que está em contínuo processo de construção impõe a necessidade de se pensar nos modos de ensinar/aprender, a fim de que os tornem mais condizentes com as demandas de formação na contemporaneidade. É preciso, então, considerar abordagens teórico-metodológicas no ensino da Geografia que (re)estabeleçam e (re)contextualizem o papel do estudante, agora considerado sujeito do processo de ensino/aprendizagem.

Diante dessas considerações, pode-se afirmar que a escola e, nesse contexto específico, a educação geográfica são percebidas como uma das vias de democratização e formação da cidadania em um mundo tão confuso. Desse modo, o processo educacional se constitui um fenômeno social e universal, que é uma necessidade para o funcionamento de todas as sociedades, isto é, toda sociedade necessita cuidar da formação dos indivíduos e prepará-los para sua participação ativa e transformadora (LIBÂNEO, 1994). Esse é um processo complexo, que pode conduzir o ser humano a ter um olhar espacial mais crítico, reflexivo do mundo, pautado, inclusive, por um olhar conformado pela realidade vivida do indivíduo, em contextos essencialmente contraditórios.

Então, refletir sobre a Educação Geográfica conduz a pensar sobre a escola, o ensino e o conteúdo, que se deve reportar ao conhecimento sobre as novas configurações do mundo atual na sociedade da informação. É preciso que se compreendam os novos tempos e espaços, os processos da globalização e as novas territorialidades que emergem diante da complexidade que se apresenta o mundo e, assim, compreendam que a Geografia, se constitui uma ferramenta intelectual para entender esse processo (CALLAI, 2011). 
Nesse contexto, e como fundamento à compreensão da realidade, a dimensão espacial do próprio lugar onde se vive, constitui-se importante via a ser considerada, pois no lugar de nossa cotidianidade se materializam os fenômenos geográficos, alguns dos quais são comuns a outras localidades.

Carvalho Sobrinho e Leite (2015) destacam a difícil compreensão da espacialidade, em virtude da dinâmica de transformações.

\begin{abstract}
Vivemos em um mundo de difícil compreensão, em virtude da dinâmica espacial, que de um modo muito rápido e intenso, contribui para alteração das formas e funções urbanas postas no cotidiano vivido pelo indivíduo. Tais transformações, que modificam a própria estrutura de organização espacial, exigem a associação dos conteúdos das disciplinas escolares ao cotidiano, nas questões que estão permeadas no contexto sociocultural dos diversos sujeitos. Nesse sentido, não há significado se esse processo evadir-se do contexto em que escola, alunos e professores estão imersos, tampouco não propiciar reflexões que impliquem na construção de significados sobre essa realidade vivida pelo grupo (CARVALHO SOBRINHO; LEITE, 2015, p.3904).
\end{abstract}

A esse respeito, esses autores consideram que o lugar do indivíduo pode contribuir para a construção de significados aos conteúdos de Geografia, especialmente aqueles vinculados à análise do urbano/cidade e, em consequência, à formação para a cidadania. De tal modo, a Geografia, como ciência e disciplina escolar, ao pensar o espaço do homem, fornece um amplo campo de reflexões, que podem conduzir à compreensão da sociedade, no sentido de identificá-la em termos de seus problemas, contradições, soluções e papel do indivíduo/sociedade nesse contexto (CARVALHO SOBRINHO; LEITE, 2016).

Pode se afirmar, então, que são pertinentes as indagações que possibilitem um entendimento acerca do papel que assume esse campo disciplinar, numa conjuntura mundial marcada pela complexidade, pelas relações e interações instantâneas, simultâneas e assíncronas, decorrentes dos avanços nas redes de comunicação tecnológica. Tais considerações têm originado concepções contemporâneas de Geografia e, nesse contexto, de Geografia Escolar, entre as quais se destacam aquelas que assinalam importância ao lugar e o apresentam como categoria analítica. Nesse sentido, o lugar, no contexto da Geografia Escolar, se apresenta como uma possibilidade de aprendizagem que parte do mundo vivido do 
aluno, o conduz à sistematização dos saberes, não só dos geográficos, mas também de outros campos disciplinares, o que reforça sua própria importância na escolarização.

Em vista disso, o lugar ultrapassa o campo disciplinar da Geografia, por promover um diálogo entre educação e contemporaneidade, articulando o local/global, que é uma necessidade do contexto escolar (LEITE, 2012). Por conseguinte, mediar o processo de construção de conhecimentos, por meio do lugar, se apresenta como um campo aberto e fértil de exploração, que objetiva conferir significados ao ato de aprender.

Mediante os pressupostos defendidos por Cavalcanti (2012), a educação geográfica assume a responsabilidade de conduzir o indivíduo à leitura do mundo e, nessa perspectiva, promover uma articulação entre conhecimentos cotidianos e científicos, a fim originar uma reflexão que se traduza em ações concretas à própria sociedade. Essas se referem às práticas cotidianas espaciais, que geram o conhecimento geográfico importante para a vida cotidiana. Afinal, compreender o mundo e ser sujeito de sua vida é a condição para viver com dignidade (CALLAI, 2011). O compreender o mundo, como já destacado, pode ser pensado, mediado e ampliado quando se valorizam as práticas cotidianas espaciais que tem sua base de concretude no lugar.

O contexto contemporâneo caracterizado pela globalização da economia imputa a necessidade de estudar o lugar como condição indispensável para o entendimento da realidade, que é confusa. Esse condicionante é justificado pelo fato das relações sociais materializarem-se em lugares diferentes e específicos. Por conseguinte, a compreensão da realidade contemporânea ocorre por meio dos significados que assume dimensão do espaço local (LEITE, 2002).

\subsection{GEOGRAFIA ESCOLAR E SUA CONTRIBUIÇÃO AO PROCESSO DE CONSTRUÇÃO DA CIDADANIA: ALGUNS PRESSUPOSTOS}

A partir da ponderação anterior, é importante considerar a complexidade envolvida no ato de ensinar/aprender Geografia, notadamente no âmbito da Educação Básica. Pode-se afirmar que a escola e a disciplina de Geografia demandam alternativas de formação mais condizentes com as demandas da sociedade contemporânea. Assim, a presente sessão 
pretende discorrer sobre o que é a Geografia Escolar e especificar sua contribuição na formação de cidadãos mais críticos, reflexivos e propositivos.

A Geografia Escolar nos leva a pensar na produção científica da Geografia ao longo de seus tempos e, diante disso, a discussão sobre o entendimento de seu significado como conteúdo escolar, por ser uma criação particular e original dos sujeitos da escola (CALLAI, 2011). Nesse sentido, pode-se afirmar que há uma inter-relação entre a Geografia Escolar e Geografia Acadêmica. Ambas se influenciam de forma mútua, guardando em si mesmas, suas identidades e peculiaridades (CAVALCANTI, 2012). Tal relação, entretanto, permite pensar um ensino de Geografia, que esteja consolidado em bases da própria ciência geográfica.

Refletir a relação entre ambas e, ao mesmo tempo, o estatuto próprio da Geografia Escolar nos faz pensar que ela é construída pelos sujeitos da escola, professores e alunos (CAVALCANTI, 2012),

\begin{abstract}
A relação entre uma ciência e a matéria de ensino é complexa; ambas formam uma unidade, mas não são idênticas. A ciência geográfica constituise de teorias, conceitos, e métodos referentes à problemática de seu objeto de investigação. A matéria de ensino de Geografia corresponde ao conjunto de saberes dessa ciência, e outras que não tem lugar no ensino fundamental e médio como Astronomia, Economia, (...) convertidos em conteúdos escolares a partir de uma seleção e de organização daqueles conhecimentos e procedimentos tidos como necessário à educação geral (CAVALCANTI, 2008, p. 2).
\end{abstract}

Enquanto componente curricular da Educação Básica, a Geografia Escolar, não é uma simplificação da ciência geográfica e mesmo possuindo relação direta com essa, não está subordinada ao que se prescreve para ela na academia. Nesse sentido, tem como perspectiva a apropriação de conteúdos que são elaborados no campo acadêmico, escolhidos e ressignificados, tendo em vista a formação da cidadania. Isso ocorre quando as escolas, por meio dos professores, trabalham os conteúdos entre o arcabouço teórico dessa ciência, que são pertinentes à prática da cidadania e que são transpostos a um contexto específico, que irá conferir a Geografia Escolar certa propriedade e peculiaridade em sua abordagem. Ela é feita pelo professor, num contexto de interação dialógica com seus alunos, que são partícipes do processo de construção coletiva do conhecimento, por isso são sujeitos, numa situação onde o papel do professor é de mediação. Desta forma, há uma relação de correspondência nas trajetórias da Geografia Acadêmica e da Geografia Escolar, mesmo sabendo que ambas 
possuem histórias paralelas, se cruzam e interpenetram e guardam suas identidades e especificidades.

Nessas trajetórias, é importante frisar, surgiram dicotomias - Geografia Física e Geografia Humana, Teoria e Prática, Professor e Pesquisador, Licenciatura e Bacharelado (entre outras) - que se traduziram em problemas relacionados à prática docente: dificuldades em relação à própria compreensão do espaço, em toda a gama de inter-relações que o qualificam, de um lado, e à complexidade de articulação dessas, de outro, que tende a se agravar em decorrência da qualidade do processo de formação do professor. Assim, no curso de desenvolvimento da ciência geográfica e da Geografia Escolar, ocorreram contextos históricos, políticos, sociais que desencadearam concepções diferenciadas sobre seu objeto, seu papel na sociedade e suas fundamentações filosóficas. Nesse sentido, no que se refere especificamente à Geografia Escolar, foi a adesão da perspectiva do materialismo histórico dialético que mais se difundiu e imprimiu significativas mudanças no modo de se pensar a Geografia, mesmo não sendo a única. Tal movimento influenciou as discussões referentes ao currículo, notadamente a partir dos anos 1980, e resultou em iniciativas de melhoria da qualidade do ensino, revisão dos conteúdos e formas de ensinar e aprender (PONTUSCHKA, PAGANELLI; CACETE, 2007).

Desta maneira, o caminho percorrido pela Geografia Escolar reflete os movimentos da Geografia Acadêmica, contudo não se confunde com a mesma. Para Cavalcanti (2008) foi a partir de 1980 por meio de novas fundamentações filosóficas, entre elas o materialismo histórico dialético, que se buscou superar a Geografia Clássica, isto é, denunciar a falsa neutralidade e o caráter utilitário e ideológico vinculado ao Estado, o que levou a redimensionamentos e reflexões acerca desse componente curricular. Alguns autores (CAVALCANTI, 2008; KAECHER, 2005; VESENTINI, 2009) vão denominar esse período como movimento de renovação da Geografia, o que para eles significa o rompimento com o fundamento positivista, onde foram incorporados novos aportes filosóficos, em especial o materialismo histórico dialético.

Nesse contexto, a pesquisa voltada especificamente para o Ensino de Geografia no Brasil começou a se consolidar a partir da década de 1980, por meio da perspectiva da Geografia Crítica, conforme atesta Cavalcanti: 
Neste momento de renovação do ensino de Geografia - na década de 1980, como já disse, predominavam ideias e caminhos alternativos que se orientavam pelo marxismo, ou pelo materialismo dialético -, questionava-se a estrutura dicotômica e fragmentada (compostas por partes estanques do discurso da Geografia (de um lado, apresentava-se os fenômenos naturais; de outro, os humanos), e algumas propostas buscavam inserir nesse discurso elementos da análise espacial. Mas do que localizar e descrever elementos da natureza, da população e da economia, de forma separada e dicotomizada, propunha-se uma nova estrutura para esse conteúdo escolar, que estivesse como pressupostos o espaço e as contradições sociais, orientado pela explicação das causas e decorrências das localizações de certas estruturas espaciais (CAVALCANTI, 2008, p. 23).

É na transição do século XX para o XXI, sob os auspícios da Geografia Crítica, que alguns pesquisadores começaram a trilhar um caminho orientado à reflexão sobre as questões de ensino/aprendizagem em Geografia na Educação Básica, currículo de Geografia, formação de professores nessa área, bem como demais temáticas direta ou indiretamente relacionadas ao universo da docência, por meio dos programas de pós-graduação em Geografia e Educação.

Essas questões que são postas no tocante à reflexão sobre a Geografia Escolar são complexas, pois o ato de ensinar não significa transferência de conhecimento. Ao contrário, como destaca Libâneo (1994), o ato de ensinar envolve a consideração de fatores culturais, sociais e econômicos, como contextualização para a aprendizagem. Além disso, exigem do professor duas particularidades em relação ao conhecimento que se propõe ensinar: o saber e o saber/fazer, quem ensina deve possuir tanto o conhecimento teórico dos conteúdos a serem trabalhados, como também, as formas didáticas e práticas para promover a internalização desses pelos alunos, no sentido de lhes habilitar a apropriação de conhecimento.

Tais considerações nos conduzem ao papel do ensino de Geografia no âmbito da Educação Básica, ou seja, desenvolver nos alunos o olhar espacial, o raciocínio geográfico, para a leitura do mundo (BRASIL, 2001). Assim, ao considerar que a educação e o ensino de Geografia têm o potencial de se constituírem instrumentos de emancipação, pode-se inferir que seu potencial para a construção da cidadania está relacionado à construção de conhecimentos, já que esse procedimento é o que permitirá o sujeito a compreender a realidade que o cerca.

Tratando-se desses pressupostos inseridos na contribuição que a Geografia traz no que se refere à noção de cidadania, Damiani (1999) constrói um raciocínio que envolve essa 
temática por meio do sentido que se tem do lugar e do espaço, já que se trata de materializações das relações humanas de todas as ordens. Conhecer o espaço, tendo o lugar como via de mediação, é conhecer a rede de relações que se está sujeito, da qual se é sujeito. Ou seja, conhecer os direitos do qual se é sujeito e os deveres a qual se está sujeito. A partir disso, perceber que tais condutas se constroem (ou deveriam se construir) através do coletivo nas suas relações recíprocas no espaço geográfico (DAMIANI, 1999).

Nesse meandro, considera-se que na Geografia ocorreram mudanças históricas, com acirramento das contradições que desembocaram em rupturas técnicas, metodológicas e temáticas. Houve uma busca por superação de uma visão geométrica do espaço, para uma visão reflexiva do espaço enquanto instância social. $O$ primeiro é considerado geometricamente, por meio de pontos e trajetos com significação reduzida. $\mathrm{O}$ segundo se refere a sua apropriação, isto é, o espaço realiza-se como instância social quando é, de fato, apropriado. É nesse sentido de apropriação que consideramos a questão da cidadania. O cidadão se definiria como tal, quando vivesse a condição de seu espaço enquanto espaço social, reconhecendo sua produção e se reconhecendo nele por meio dos usos cotidianos (DAMIANI, 1999).

Na esteira dessas considerações críticas, Santos (2000, p. 13) evidencia que "em lugar do cidadão formou-se um consumidor, que aceita ser chamado de usuário". Essa noção engloba todo o mundo, mas em um país como o nosso, essa formação de um consumidor em detrimento ao cidadão é algo que assombra, pois os direitos sempre estão atrelados, apenas, na existência de bens materiais. Assim, o ensino dessa disciplina se afirma como fundamental à formação de mentalidades, contribui para a construção da noção de cidadania da geração atual e das futuras, as quais terão que gerenciar um mundo marcado pela complexidade, pleno de contradições e desigualdades (LEITE, 2002).

Ainda para Leite (2012) o lugar vincula a formação para a cidadania na medida em que os sujeitos se identificam como ativos no contexto da produção da vida em sociedade. Reverbera que formar um cidadão no contexto da escola contemporânea, denota dar condições ao aluno para se reconhecer como um sujeito que possui história, que tem conhecimento prévio do mundo e que é capaz de construir seu conhecimento, ou seja, entender que as relações espaciais são resultados da sua própria vida. 
Em vista disso, uma das funções primordiais da escola é a formação para a cidadania, mas quais são os delineamentos do significado desse conceito? Formar cidadão está relacionado com um projeto que tem como ponto central a participação política e coletiva das pessoas, nos destinos de uma sociedade. Tal participação deve estar ligada a uma democracia participativa, assim, esse conceito, pressupõe a concepção do próprio espaço público com as identidades construídas pelos cidadãos (CAVALCANTI, 2008).

É preciso compreender que o conhecimento adquirido na escola por meio das disciplinas, no qual a Geografia se faz presente, deve conduzir o sujeito ao exercício de seus direitos e deveres relativos à cidadania, como aponta Cavalcanti:

Cidadão é aquele que exerce seu direito a ter direitos, ativa e democraticamente, o que significa exercer seu direito, inclusive, criar novos direitos e ampliar outros. É no exercício pleno da cidadania que se torna possível, então, transformar direitos formais em direitos reais (2008, p. 85).

Eis, então, que a escola e o processo de escolarização devem caminhar, no sentido de contemplar a formação de cidadãos conscientes, reflexivos, críticos e propositivos. Nesse contexto, as práticas pedagógicas da disciplina se tornam relevantes, especialmente no que se refere à dinâmica de formação da cidadania, por meio da construção de conhecimentos geográficos, a partir da realidade vivida pelos sujeitos. Advogamos que o ideal seria pensar em uma Geografia Escolar, que faça ligação com a vida cotidiana do aluno para que construa sua própria identidade e pratique a cidadania no contexto de sua coletividade.

O ensino da Geografia pode e deve ter como alvo central a educação para a cidadania, mostrar ao aluno que cidadania é também o sentido de pertencimento a uma realidade, em que as relações entre sociedade e a natureza formam um todo integrado (em constante transformação) do qual faz parte. É necessário conhecer o lugar ao qual se pinta membro participante, responsável e comprometido historicamente com os valores humanísticos (BRASIL, 2001).

É nesse sentido que Cavalcanti (2012) evidencia a questão das pesquisas voltadas ao ensino de Geografia:

As pesquisas na linha do ensino de Geografia no Brasil têm sido produzidas com o intuito de compreender a dinâmica desse processo e de indicar 
caminhos e abordagens que melhores resultados produzam (ou podem produzir) na aprendizagem e na formação do cidadão (CAVALCANTI, 2012.p. 5).

Na visão dessa autora, o ensino de Geografia contribui para a formação da cidadania por meio da prática de construção e reconstrução de conhecimentos, habilidades e valores, que ampliam a capacidade de crianças e jovens compreender o mundo em que vivem e atuam, numa escola organizada como um espaço aberto e vivo de culturas.

Nessa linha de raciocínio Callai (1995) argumenta que,

A educação para a cidadania é um desafio e a Geografia é uma das disciplinas fundamentais para tanto. O conteúdo das aulas de Geografia deve ser trabalhado de forma que o aluno construa a sua cidadania. (...) Se a formação do educando para ser um cidadão passa pela ideia de prepará-lo a "aprender a aprender", a "saber fazer", o papel das disciplinas escolares e da Geografia particularmente, tem a ver com o método, quer dizer de que forma se irá abordar a realidade (p.206).

Explicitar o sentido da Geografia Escolar, por meio da construção da cidadania, é um desafio a ser enfrentado. Ensinar Geografia tem uma amplitude muito maior que simplesmente memorizar conteúdo ou mesmo preparar para um vestibular. Se o objeto a ser analisado é o espaço, onde acontecem todas as atividades humanas, desde as mais simples às mais complexas, essa disciplina adquire um status maior, qual seja: contribuir para o exercício da cidadania no sentido do cumprimento dos direitos e deveres perante a coletividade.

Nesse contexto, o exercício da cidadania melhor se efetiva quando o sujeito possui o conhecimento sistematicamente elaborado pela sociedade em seu processo histórico, por possibilitar a reflexão da sua própria inserção e organização no espaço. Em outros termos, o ensino da Geografia tem a incumbência de levar o aluno a compreender a sua realidade, desenvolver sua intelectualidade por meio da construção do conhecimento. Conforme Macêdo (2016),

O ensino de Geografia, nas escolas do ensino básico, tem o papel primordial de educar para a cidadania, ou seja, formar cidadãos que compreendam a sua realidade, o mundo em sua complexidade - as contradições socioespaciais no decorrer da história, e desse modo, sejam capazes de participar de forma ativa na transformação dos seus espaços de vivência, respeitando as suas diversas dimensões, de forma ética e responsável (p.153). 
Nesta intenção, a Geografia se volta para a compreensão das contradições socioespaciais e desse modo, induz os sujeitos a participar ativamente da transformação da sociedade. Considerar a experiência do aluno, para que a realidade seja problematizada, e levar em consideração os espaços de vivências é uma função primordial do ensino de Geografia.

No entanto, no ensino da Geografia e as práticas de ensino que são implementadas no âmbito da Educação Básica são, cada vez mais, desafiadoras por não considerar os espaços de vivências para a problematização e construção de conhecimentos. Como superar as práticas tradicionais em uma disciplina, cuja apresentação se faz monótona, conteudista e enfadonha? A resposta a essa questão conduz a reflexões sobre alternativas metodológicas, que promovam a possibilidade de pensar o espaço geográfico mediante o lugar, como ponto de partida e chegada e, nesse contexto, desenvolvam o sentido de cidadania crítica, reflexiva e propositiva.

Concordamos com Morais e Cavalcanti (2011, p. 28) que a compreensão da lógica que estrutura o espaço urbano e rural permite a aproximação e a efetivação do exercício da cidadania. A cidadania está além de questões legais. O ser cidadão envolve a atuação na gestão e planejamento da cidade, no sentido de lutar por direitos que são coletivos. "Ser cidadão significa, portanto, ter uma postura crítica, ativa, participativa, aberta e transformadora" (MORAIS; CAVALCANTI, 2011, p. 28).

Por essas considerações, percebe-se que a Geografia Escolar possibilitará que os alunos se reconheçam como cidadãos e compreendam sua atuação no espaço, a partir do momento que construção de conceitos envolva a dimensão do lugar. Assim, "ao se apropriar de um conceito, o aluno precisa dar-lhe significado, inserir a nova informação para alterar esquemas, criando uma estrutura de pensamento, que pode ser simples, por exemplo, relacionando os fenômenos estudados com os do cotidiano e, com isso, estimulando as mudanças conceituais" (CASTELLAR; VILHENA, 2010, p.99-100).

Observa-se que a utilização do lugar é sugerida por pesquisadores e professores da área, no intuito de estabelecer condições de significação aos conteúdos em Geografia, para viabilizar a internalização de conceitos, que façam sentido ao aluno, no processo de pensar a espacialidade e conseguir efetuar a leitura de mundo. É possível e relevante, relacionar o estudo do lugar como uma condição para o exercício da cidadania. 
Diante do exposto, pode-se concluir que construir conhecimentos em Geografia, conferir significados aos mesmos, associá-los à leitura de mundo, à formação da cidadania, encontra uma possibilidade metodológica interessante por meio do lugar, conforme poderá ser constatado no item que se segue.

\subsection{ESPAÇO, LUGAR E ENSINO DE GEOGRAFIA: INTER-RELAÇÕES}

Parte-se do pressuposto que a Geografia dispõe de ferramentas para estudar seu objeto, o espaço geográfico. Nesse sentido, o lugar se apresenta como uma das alternativas para conhecer os significados e valores que são construídos pelos indivíduos no espaço. Nesse contexto, é essencial compreender as dinâmicas sociais, para a construção de uma sociedade que pense o espaço do homem e sua plenitude humana. Para que isso ocorra é necessário considerar o espaço geográfico como "produto das relações entres os homens e dos homens com a natureza, que ao mesmo tempo é fator que interfere nas mesmas relações que os constituíram" (ALVES, 2015, p. 134). Nesse sentido, a Geografia entende que o espaço se constitui nas materializações das relações que existem entre natureza/homem/sociedade.

O espaço e o lugar são conceitos que não se separam, pois é a partir de um espaço diferenciado, que aos poucos vai sendo experimentado e vivenciado, que se tem a constituição do lugar, isto é, o próprio ser humano vai dotando o espaço de valor e adquirindo significado (TUAN, 2013). De acordo com o mesmo autor,

O espaço é sem dúvida, mais que um ponto de vista ou um sentimento complexo e fugaz. É uma condição para a sobrevivência biológica. O espaço é uma necessidade biológica de todos os animais, é também para os seres humanos uma necessidade psicológica, um requisito social, e mesmo um atributo espiritual (p.76).

A partir dessa consideração, o espaço além de uma condição para a sobrevivência, é onde o ser humano pode realizar todas as suas atividades, desde as mais simples até as mais complexas. Tanto o espaço, como o lugar, são como uma necessidade humana, estando ligado um ao outro.

As pessoas criam e recriam os lugares através do movimento objetivo e subjetivo dessa experiência e é nesse sentido, que essas experiências devem ser levadas em consideração. 
Portanto, o espaço dos alunos que possui a marca do movimento, deve ser aberto para incorporar o que foi produzido e conseguir em sua dinâmica vivenciada, construir adiante.

L'homme est acteur géographique, le lieu est son espace de vie; toutes lês relations s'y mêlent dans um écheveau de liens véhiculant nos sentiments, nos mémoires collectives et nos symboles. Localisation, forme, structure, activités concourent à le différencier des autres, mais son caractere distinctif émane essentiellement des valeurs, des significations et des aspirations ressenties par l'homme (BAILLY; SCARIATI, 2001, p. 216). ${ }^{1}$

Ao pensar na perspectiva de lugar como o espaço da vida, percebe-se uma relação entre as questões identitárias dos seres humanos, devido à experimentação que marca profundamente a vida desse sujeito. Ou seja, o ser humano como sujeito ativo na construção do espaço o faz por meio das relações que se travam no lugar, construindo identidades. Tais considerações objetivam reforçar a importância da categoria lugar na Geografia.

Como atesta Ferreira (2000),

O conceito lugar, considerado por muito tempo como um dos mais problemáticos da Geografia, tem se destacado, recentemente, como uma das chaves para a compreensão das tensões do mundo contemporâneo [...], o lugar tem se apresentado como um conceito capaz de ampliar as possibilidades de entendimento de um mundo que se fragmenta e se unifica em velocidades cada vez maiores (p.65)

Desta maneira, quando se propõe fazer a análise entre espaço, paisagem e lugar, este talvez seja o mais importante, ao focalizar o espaço e a paisagem por meio das intenções e significações humanas, isto é, o espaço e o lugar não se separam (RELPH, 1976). Os pesquisadores, que se dedicam a estudar o lugar, afirmam que esse conceito além de possuir uma relação inseparável com o espaço reafirma, “em seus vários espaços e sentidos, que é uma idéia-chave para enfrentar os desafios cotidianos. É no lugar que os problemas nos atingem de forma mais dolorida, e é também nele que podemos melhor nos fortalecer" (MARANDOLA JR; HOLZER; OLIVEIRA, 2012, p. 15).

Para Bailly e Scariati (2001),

\footnotetext{
${ }^{1} \mathrm{O}$ homem é ator geográfico, o lugar é seu espaço de vida; todas as relações se misturam em uma teia de ligações que transmite nossos sentimentos, nossas memórias coletivas e nossos símbolos. Localização, forma, estrutura, que contribuem para diferenciá-lo de outros, mas o seu caráter distintivo emana essencialmente valores, significados e aspirações sentidas pelos seres humanos (BAILLY; SCARIATI, 2001, p. 216).
} 
Un lieu n'est pas une collection d'objets et d'événements, mais une mémoire collective. Cela nous amène à nous poser la question de lafinalité La géographie. Découvrirdes de systèmes spatiaux quantifiables ou comprendre Le vécu dês habitants? Pour l'approche humaniste, comment concevoir une géographie sans referential habitant, sans etude des objets signés, sans rendre compte des experiences humaines? Seule une lecture intériorisée du vécu humain peut nous permettre comprendre lês hommes et de lês impliquer dans l'oeuvre géographique (p. 215). ${ }^{2}$

Diante do exposto, pode-se afirmar que, nos últimos anos, o conceito de lugar vem sendo resignificado diante da ciência geográfica, em particular, pois se constitui uma referência à mediação dos significados que são construídos no espaço geográfico.

Santos (1996) contribui com o debate da relação espaço e lugar ao destacar que "mais importante que a consciência do lugar é a consciência do mundo, obtida através do lugar" (SANTOS, 2008, p.161). O lugar com suas particularidades, similaridades e contradições reflete o particular e ao mesmo tempo o holístico, sendo esse aspecto preponderante para a ressignificação de apreender/ensinar Geografia nessa sociedade. Além disso, o lugar nos permite confrontar a realidade vivida com o conhecimento acumulado. O mesmo autor enfatiza que, “[...] não posso ser holístico sem trabalhar com o particular” (1994, p. 168).

[...] o papel do lugar é determinado. Ele não é apenas um quadro de vida, mas um espaço vivido, isto é, de experiência sempre renovada, o que permite, ao mesmo tempo, a reavaliação das heranças e a indagação sobre o presente e o futuro. A experiência naquele espaço exerce um papel revelador sobre o mundo (SANTOS, 2009, p.114).

A experiência renovada, ressignificada e sempre em movimento que é travada no espaço se revela por meio do lugar. É nesse sentido que o lugar é um revelador do mundo. A ação de experimentar envolve o espaço e leva os humanos a recriar e ressignificar os espaços, construindo lugares. Não existem indivíduos fora do espaço e, simultaneamente, do lugar. Logo, não se pode pensar o lugar sem pensar no espaço como objeto principal de estudo da Geografia. Portanto, compreende-se que, não existe lugar sem a relação que se trava no

\footnotetext{
${ }^{2}$ Um lugar não é uma coleção de objetos e eventos, mas uma memória coletiva. Isso nos leva a nos perguntar a questão do propósito da Geografia. Descobrindo sistemas espaciais quantificáveis ou compreender as experiências dos habitantes? Para a abordagem humanista, como projetar uma Geografia sem os referenciais dos habitantes, sem estudo de objetos assinados, sem perceber as experiências humanas? Apenas uma leitura internalizada da experiência humana pode nos ajudar a compreender os homens e envolvê-los na obra geográfica (p. 215).
} 
próprio espaço com objetos pertencentes a essa teia. O lugar é entendido como uma dimensão social (causa e efeito), que se vincula com o local-global. "Cada lugar é, ao mesmo tempo, objeto de uma razão global e de uma razão local, convivendo dialeticamente" (SANTOS, 1996, p.273).

Tais conceitos, no âmbito do ensino de Geografia, se traduzem como importante via de mediação para a construção e reconstrução dos conhecimentos geográficos. Assim,

\begin{abstract}
Estudar o lugar, em Geografia, constitui-se parte importante da Educação como ferramenta mediacional na construção dos processos identitários. Trabalhar na perspectiva do lugar permite a incorporação da subjetividade, também por meio de emoções e sentimentos, que são representados nos processos de construção dos significados. Considerando-se que a realidade que se atribui ao mundo é uma realidade construída, estudar o lugar, então, constitui-se alternativa concreta de compreensão da realidade; de identificação; de reafirmação, ou não, das identidades individual e coletiva; de construção do self, e do desenvolvimento humano (LEITE, 2012, p.22).
\end{abstract}

O lugar é uma construção a partir da experiência no próprio espaço, sendo importante na construção de conhecimentos que sejam significativos. Nesse contexto, exige-se do docente uma prática pedagógica que fuja das metodologias de ensino tradicional e que sejam compatíveis com a formação do sujeito do século XXI, notadamente na compreensão do espaço geográfico por meio do lugar, considerando as características do espaço na contemporaneidade (LEITE, 2011).

O trabalho docente orientado para o desenvolvimento teórico dos alunos se desenvolve buscando estabelecer, com a intervenção deliberada do professor, a relação do aluno com o mundo objetivo. Nessa relação, o aluno desenvolve sua capacidade mental, sobretudo a de formar conceitos, para lidar com o mundo. Ajudar a formar conceitos é, portanto, papel central do professor (158).

Tais considerações, aplicadas e vinculadas ao ensino de Geografia, sugerem a “compreensão do lugar para compreender o mundo" (CALLAI, 2000, p.71), isto é, levar o aluno a pensar o espaço geográfico, por meio das relações estabelecidas em seu lugar e saber relacioná-lo a um contexto mais global. Para a autora,

Compreender o lugar em que vive permite ao sujeito conhecer a sua história e conseguir entender as coisas que ali acontecem. Nenhum lugar é neutro, 
pelo contrário, é repleto de história e com pessoas historicamente situadas em um espaço maior, mas por hipótese alguma é isolado, independentemente (CALLAI, 2000, p.72).

O lugar é um espaço construído como resultado da vida das pessoas, dos grupos que nele vivem, das formas como trabalham, como produzem, como se alimentam e como fazem e usufruem do lazer, é a própria realidade, o lugar onde se vive caracterizado pela experiência e pelo mundo vivido (CALLAI, 2011). No contexto de valorização do lugar no ensino de Geografia é defendido que:

Tais considerações nos permitem inferir que a abordagem e a valorização do lugar convergem em um aprendizado que não seja estanque, mas que faça parte do cotidiano vivido do aluno, sendo trabalhado na perspectiva de compreensão do espaço geográfico, conforme atesta Callai (2000, p. 84) "estudar e compreender o lugar, em Geografia, significa entender o que acontece no espaço onde se vive para além das suas condições naturais ou humanas". Assim, o lugar constitui-se um dos pilares centrais no ensino de Geografia e um conceito relevante a ser trabalhado no âmbito da Educação Básica.

O lugar é uma mescla dos aspectos da espacialidade do aluno e pode ser uma referência constante na mediação orientada ao ensinar/aprender, que implica na consideração do aluno como sujeito ativo no processo de construção do conhecimento. Desse modo, a utilização do lugar evidencia-se como um elemento articulador de experiências e conhecimentos, relacionado à totalidade do espaço, por meio, também, das redes que viabilizam as inter-relações das escalas local, regional, nacional e global.

Cavalcanti (2008) sistematiza as relações entre as escalas de abordagem por meio do conceito de lugar, conforme pode ser observado na figura 1. Essa sistematização considera o lugar como uma rede que pode conduzir a explicação e relação do local com o global, aspecto relevante no período contemporâneo vivenciado pelas sociedades. Elementos, tais como: localização, orientação, cotidiano, afetividade, familiaridade e identidade são inclusões que são travadas a nível global e origina processos e relações de diferenciação dos espaços mundiais, mas que são concretos em um lugar específicos e se relacionam com as demais localidades por meio da relação local-global. 
Figura 1 - Sistematização do conceito lugar.

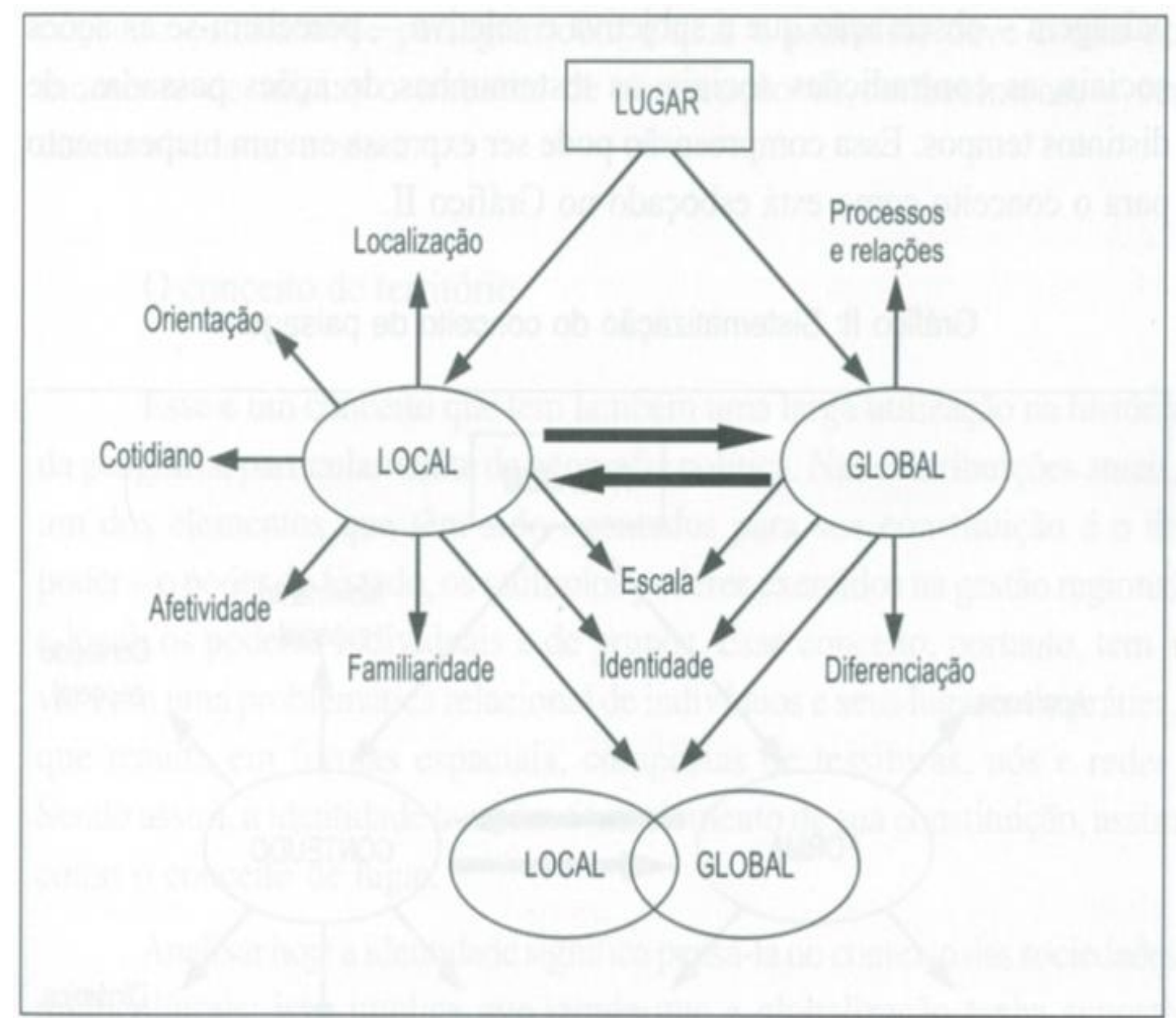

Fonte: Cavalcanti (2008, p. 51).

A esse respeito Macêdo (2016) complementa a ideia referente à mediação pelo lugar, ao afirmar que a ligação e aproximação dos saberes cotidianos aos conteúdos estudados auxiliam na compreensão dos alunos, pois o que observam e estudam têm aplicação em suas vidas de forma concreta. É nesse sentido, então, que deve ocorrer à aprendizagem em Geografia, com aulas que possibilitem conduzir os alunos a refletir sobre o seu espaço cotidiano, tendo em vista a construção do seu próprio aprendizado. É nessa prática cotidiana que se constroem conhecimentos geográficos, ou seja, o aluno experimenta a dinâmica espacial e nela constrói representações, que devem ser confrontadas, ampliadas e discutidas com o saber geográfico mais sistematizado, por meio da mediação pedagógica do professor, no processo de construção coletiva do conhecimento (CAVALCANTI, 2012).

Entretanto, a prática pedagógica em Geografia, conforme demonstra Straforini (2008), apresenta-se com alguns complicadores no que se refere à mediação pedagógica do professor. 
Entre esses, a abordagem do lugar, que é feita de modo fragmentado, sem relação de causa e efeito entre as distintas escalas, do local ao global. Nesse sentido, e de acordo com o apontado anteriormente, é papel do professor, por meio de sua mediação pedagógica, evitar a hierarquização e fragmentação de cada dimensão espacial, ou seja, estabelecer as relações de interdependência entre as várias escalas de abordagem do lugar. Ao trabalhar nessa perspectiva, o que deve ficar claro são as relações entre os fenômenos para a produção do espaço.

Assim, a espacialidade adquire uma relação de proximidade muito maior para as pessoas, pois as relações globais em sua dimensão espacial se materializam no lugar por meio das várias dimensões espaciais: casa, bairro, cidade, estado, região, país, continente e mundo, que se encontra em uma relação cada vez mais íntima (STRAFORINI, 2008). Portanto, a categoria lugar é fundamental ao estabelecimento de relações com a totalidade. É nesse sentido, que se torna desafiador a prática pedagógica, que não esteja alheia a si mesma, mas relacionada com várias escalas do mundo.

Nesse sentido, como construir conhecimentos geográficos significativos a partir do cotidiano do aluno? Defende-se, então, que esse processo acontecerá e será significativo, se o aluno efetuar as relações local-global, por intermédio dos elementos vividos e conhecidos no cotidiano, que representam a concretude das ações globais, materializadas no lugar. Isso possibilitará que os alunos promovam análises mais sistematizadas sobre o mundo, mas de forma crítica, reflexiva e propositiva.

Straforini (2008, p. 93) afirma que "o lugar oferece ao movimento do mundo a possibilidade de realização mais eficaz. Para se tornar espaço, o mundo depende das virtudes do lugar". Assim, acredita-se que a categoria lugar seja um dos principais recursos para construção da ciência geográfica e, também, dessa disciplina escolar.

No âmbito escolar, Callai (1999) afirma que um aluno que compreende sua realidade vivida, consegue perceber que o espaço é construído. Em consequência, terá maior facilidade no seu processo de aprender, pois tal aprendizado vincula-se ao seu cotidiano. Desse modo, o conhecimento geográfico deverá retratar a realidade do aluno, para que ele possa construir seu aprendizado por meio do lugar, para a compreensão do espaço que foi e é construído. De tal modo que, "as experiências concretas deverão ter interligamento e coerência dentro do que é ensinado, pois o vivido pelo aluno é expresso no espaço cotidiano, e a interligação deste com 
as demais instâncias são fundamentais para a aprendizagem" (OLIVEIRA, 2015, p. 16).

Diante do exposto até o momento, pode-se perceber que é o conceito de lugar que viabilizará o processo de significação de conteúdos em Geografia, para que o aluno possa efetuar a leitura crítica e reflexiva do mundo. Entretanto, essa intenção precisa de uma dimensão espacial concreta, que no caso a ser evidenciado nesta pesquisa será dada pela cidade, conforme pode ser verificado no item que se segue.

\subsection{CIDADE: VIVÊNCIA E EXPERIÊNCIA COM OS FENÔMENOS GEOGRÁFICOS ${ }^{3}$}

Esta seção apresenta, inicialmente, análise e reflexão sobre uma dimensão espacial concreta que se vive e experimenta os fenômenos geográficos do espaço, a cidade. Posteriormente, direciona-se o olhar a respeito da cidade sobre o prisma do ensino da Geografia, a partir do qual a cidade é analisada como um lugar de vivência e experiência com os fenômenos geográficos.

A partir de considerações de pesquisadores de diferentes áreas do conhecimento, a cidade se tornou objeto de inúmeros estudos, sendo considerada, por muitos, como via de formação das pessoas e da sociedade em geral. Nessa perspectiva, a presente investigação pensa a cidade como um lugar de formação, em decorrência da sua complexidade e dos fenômenos geográficos que aí se manifestam (CAVALCANTI, 2008).

Nesse cenário de mundo globalizado, onde o processo de urbanização constitui-se uma das características mais incisivas da contemporaneidade, a cidade assume um caráter de extrema importância. No caso do Brasil, por exemplo, as cidades abrigam aproximadamente $84 \%$ da população brasileira (IBGE, 2016), sendo marcadas por forte multiculturalismo e diversos modos de convívio urbano, que de certo modo enriquecem a vida cotidiana e as manifestações que aí se materializam. Por isso Cavalcanti (2008) afirma que a cidade se constitui como os lugares de encontros e de diferenças, que são ricas e relevantes para a prática espacial cotidiana.

\footnotetext{
${ }^{3}$ A opção por trabalhar o lugar a partir da cidade está relacionada ao recorte espacial da pesquisa. Não há intenção de menosprezar ou mesmo diminuir o campo, pois sabemos que também se constitui como lugar de vivência e experiência com os fenômenos geográficos.
} 
Concordamos com a ideia que as cidades se constituem centros da vida social, onde se acumulam, não apenas as riquezas produzidas, mas também conhecimentos e cultura. Ou seja, há uma infinidade de ações e objetos produzidos pelos seres humanos, o que origina uma espacialidade bastante complexa e contraditória (LEVEBVRE, 1991).

Ao considerar a definição de cidade de Harvey, Corrêa (2001), pondera que é uma forma de organização do espaço pelo homem e também, uma expressão concreta de processos sociais na forma de um ambiente edificado sobre os meios geográficos. Para esse autor, existem modeladores da organização do espaço: proprietários dos meios de produção, os donos da terra, as empresas do grande capital e o próprio estado. Assim, acabam por excluir grande parte da sociedade, no que diz respeito aos usufrutos dessa organização, devido à própria dinâmica do modo capitalista de produção, que tem como base o processo terracapital-trabalho que intensificou o processo de urbanização.

Nesse sentido, a cidade aumenta de forma brusca em sua superfície total e o fenômeno da especulação segue o mesmo ritmo. Morar na periferia da cidade é o destino dos pobres, que são condenados a não dispor de serviços sociais ou utilizá-los precariamente (SANTOS, 2000). É nesse sentido que as sociedades, prioritariamente nas cidades, convivem com sonhos e pesadelos.

La polysémie des espaces vécus, superposition de représentations, rend ne cessaire cette nouvelle approche. La région, laville, Le quartier, miroir de nos sociétés, sont à La fois rêves et cauchemars. Au géographe de lês étudier pour devenir um interlocuteur valable face aux technocrates de l'amé nagement et aux théoriciens du développement par le haut. À ne pás intégrer la richesse dês rapports intériorité humaine-symbolique dês lieux, la géographie désincarnée perdra son savoir géographier (BAILLY; SCARIATI, 2001, p. 219). ${ }^{4}$

A cidade também é um lugar de injustiças sociais, onde os bairros com rendas mais baixas são os menos equipados (SCARLATO, 2011). Tuan (2012) também faz essa reflexão em relação aos status sociais diferentes, sendo que a cidade acaba tendo partes separadas gerando a segregação social. Para o mesmo autor, as cidades são as estruturas materiais mais

\footnotetext{
${ }^{4}$ Os múltiplos significados dos espaços vividos, sobreposição de representações, exige uma nova abordagem. A região, cidade, bairro, espelho das nossas sociedades, são ambos os sonhos e pesadelos. O geógrafo estuda para se tornar um interlocutor válido face aos tecnocratas do desenvolvimento e dos teóricos do desenvolvimento de cima. Sem integrar a riqueza das relações íntimas humanas-simbólicas dos lugares, a Geografia desencantada perde seu saber geográfico (BAILLY; SCARIATI, 2001, p. 219).
} 
complexas que o homem já construiu e corresponde a um ambiente radicalmente transformado.

Em consequência, a cidade é mais do que as materializações das relações sociais e de produção, é todo um modo de viver, pensar e sentir (CARLOS, 2013). É complexa e abriga uma infinidade de modos de vida. Nesse sentido, estudiosos de várias áreas do conhecimento têm dedicado um olhar especial à cidade, como intuito de perceber as questões cotidianas, a política urbana, a gestão, o planejamento, transporte, abastecimento, saúde, segurança, educação, entre tantos outros.

A cidade é ativa, não deve ser pensada ou mesmo visualizada como algo inerte, mas sim como um espaço que está vivo (DARDEL, 2011). Como destaca Sposito (2013), para entendê-la não basta apenas observá-la ou nela viver, mas é necessário a verificação de sua dinâmica, de sua história e Geografia, que contemplam os variados processos que a produzem e a caracterizam, frutos de conteúdos e formas manifestadas ao longo do tempo, no espaço.

A partir disso, muitas possibilidades emergem ao pensar a cidade sob o prisma do habitar e da construção de conhecimentos, por meio dos objetos, ações e relações que acontecem na mesma. Para Lefebvre (1991), a cidade envolve o habitar por meio do local em que constitui a vida privada, ponto de partida e chegada. Dessa forma, é necessário considerar as relações imediatas, o cotidiano, o inconsciente, os problemas, por se constituir um espaço com múltiplos significados e que abriga variados conceitos.

Diante dessas concepções, torna-se necessário ressaltar o sentido de cidade a ser considerado nesta investigação: a cidade é uma dimensão do vivido, logo, esfera e lugar da vida que pode ser utilizada para a construção de conhecimentos significativos no ensino de Geografia. Por meio dessa consideração apontamos que, nos últimos anos, várias pesquisas têm assinalado para a necessidade de refletir a cidade como objeto de estudo no ensino da Geografia (BENTO 2011; CASTELLAR, 2009; CAVALCANTI, 2008; OLIVEIRA, 2015; SILVA, 2016). Tais pesquisas evidenciam que os conteúdos e conceitos geográficos devem considerar a cidade no processo de sistematização dos conhecimentos geográficos. De tal modo,

A cidade é também assunto de preocupação dos estudiosos da área de educação escolar, como os que se dedicam ao estudo do ensino de Geografia, pois não se trata apenas de um conteúdo específico a ser 
veiculado na escola, em diferentes níveis, mas é também parte das tarefas de formação da cidadania, em sentido mais abrangente, a serem cumpridas por ela (CAVALCANTI, 2008, p. 7-8).

Fazer da cidade uma via de compreensão da realidade é possibilitar o processo de significação no processo de ensinar/aprender Geografia. Os alunos precisam entender as várias dimensões, enfoques e arranjos espaciais da cidade, para que assim possa construir conhecimentos, que serão aplicados no seu cotidiano, como via de compreensão dessa realidade. Há de se considerar, ainda, que o próprio currículo escolar destaca a cidade e o lugar de vivência como um dos temas que estruturam a análise geográfica. Nesse sentido, a cidade passa a ser pensada, não somente, como um conteúdo a ser transmitido pela Geografia, mas como um instrumento de consciência cidadã, vivência e também de ensino/aprendizagem.

Todas as cidades educam, na medida em que a relação do sujeito, do habitante, com esse espaço é de interação ativa e dialética e trazer essa experiência, real e cotidiana, como parte integrante da ação pedagógica, leva a eficácia do processo de aprendizagem a um patamar superior (CASTELLAR; VILHENA, 2010, p. 127).

Nessa perspectiva, a cidade é compreendida como um dos lugares de vivência que pode ser significada pelos professores em seus diversos espaços e tempos para a construção do conhecimento em Geografia. "A cidade é educadora: ela educa, ela forma valores, comportamentos, ela informa com sua espacialidade, com seus sinais, com suas imagens, com sua escrita. Ela também é um conteúdo a ser apreendido por seus habitantes" (CAVALCANTI, 2008, p. 74).

Ter a cidade como objeto de estudo geográfico é estudar os seus sistemas de entradas e saídas; suas vias de acesso em vários pontos; as inte-relações com as aglomerações populacionais; a dinâmica econômica e cultural de seus moradores - que gera características particulares dos bairros -; as relações socioambientais que se estabelecem; o quadro da saúde pública; em suma, os diversos elementos que compõem a paisagem do lugar (CASTELLAR; VILHENA, 2010, p. 123).

Importante destacar que tais considerações atestam que a Geografia não se restringe aos conhecimentos referentes à localização espacial, mas se volta para a exploração do espaço da vida e dos homens como meio social. Por conseguinte, a cidade deve ser explorada para fins pedagógicos e sociais. Nesse sentido o aluno, ao conhecer sua cidade e por meio dos 
exemplos e situações aí existentes, poderá construir conceitos e conhecimentos para ampliar sua visão acerca do mundo. Carlos (2004) corrobora com tal ideia ao considerar que:

A cidade, mais do que a materialidade das relações sociais de produção, é todo um modo de viver, pensar e sentir. Ela é o lugar privilegiado do urbano, fenômeno que em parte existe na vida cotidiana das cidades e, ao mesmo tempo, está posto em sua totalidade, sendo parte de um processo em constituição na sociedade, ainda não realizado em todas as suas possibilidades (p. 135).

Por consequência, assume-se que o estudo da cidade seja um lugar profícuo para práticas escolares, pois é o lugar onde ocorre a maioria dos múltiplos eventos, que são importantes para a prática da cidadania. A esse respeito Castellar (2010, p. 45) afirma que "a aprendizagem será significativa quando a referência do conteúdo estiver presente no cotidiano da sala de aula, quando se considerar o conhecimento que a criança traz consigo, a partir de sua vivência". Em consequência, pode-se concluir, que cidade e lugar unem-se para resultar num aprendizado significativo, que avance na perspectiva de compreensão do espaço geográfico. De acordo com Cavalcanti (2002),

[...] a cidade considerada conteúdo escolar, não é concebida apenas como forma física, mas como materialização de modos de vida, como um espaço simbólico, formador de sentidos de pertinência e de identidade fundamental para a formação da cidadania. Sendo assim seu estudo volta-se para desenvolver no aluno a compreensão do modo de vida da sociedade contemporânea e de seu cotidiano em particular (p.75).

Considerando-se o caráter socioeducativo das cidades, Cavalcanti (2008) propõe uma metodologia para sua análise, que perpassa pela identificação de suas áreas comerciais e residenciais, seu centro histórico, sua morfologia, seu perfil socioeconômico e demográfico, áreas de ocupação irregular, conflitos e contradições, dimensões culturais de seus habitantes, características naturais, entre outros. Tal sugestão metodológica, porém, impõe ao professor um conhecimento mínimo sobre o lugar, como condição para que ocorram os processos de mediação pedagógica. Portanto, será preciso, não somente, que os professores estejam atentos e compreendam que, por meio dos espaços vivenciados e experimentados pelos alunos no dia a dia, é possível uma condução de aprendizagem significativa, como também, e principalmente, que conheçam a cidade/lugar que mediará a construção coletiva do conhecimento geográfico. Assim, ao optar e valorizar a cidade e as cotidianidades dos alunos, os professores estarão contribuindo para sua inclusão no processo de aprendizagem, 
construindo conhecimentos.

É importante ratificar que a cidade possui inúmeros espaços públicos para a realização da vida pública e, diante disso, se apresenta como um caminho para subsidiar a formação para a cidadania, conforme explicitado anteriormente. Em uma reflexão sobre espaço público e a cidade Silva (2016) evidencia que,

Os espaços públicos na cidade deveriam cumprir esse objetivo de ser o local da reunião, do encontro, o locus privilegiado da realização da vida pública. A escola pública teria, do mesmo modo, também essa função de reunir diferentes pensamentos, culturas, sujeitos, além de ter como pauta os conhecimentos sobre cidade como forma de subsidiar a formação cidadã ( $\mathrm{p}$. 165).

Nessa linha de pensamento Bento (2011) considera que,

A cidade, por sua vez, inscreve-se também na escola, contra a pretensão homogeneizadora escolar, a cidade se lhe apresenta continuamente como uma experiência do heterogêneo e do múltiplo. A cidade se impõe à escola como pluralidade de sujeitos, de culturas, de instituições, de estímulos, de sensibilidades, ou seja, como uma experiência de aprendizagem muito diversificada [...] (p. 80).

Se a cidade está inserida em uma multiplicidade de fenômenos e diversidade, seu conteúdo ao ser evidenciado e considerado no processo de aprendizagem faz com que a escola busque exercer a sua função principal: formar o cidadão.

Nesse sentido, considera-se que a cidade seja analisada enquanto espaço vivido do aluno; que seus espaços sejam desfrutados para a promoção de uma proposta pedagógica enraizada na realidade; que seja aproveitada pelos docentes, para a realização de propostas educativas, que possibilitem uma aprendizagem mais significativa, ou seja, que os sujeitos sociais compreendam que podem transformar a sua cidade, e por meio dela, produzir e reproduzir o espaço.

As considerações efetuadas até o momento convergem para apresentar uma vinculação dos conceitos de cidade e lugar, como fundamentais ao processo de ensino-aprendizagem de Geografia, por promover uma dinâmica relacional que resulte na compreensão da espacialidade. Nessa perspectiva, a grandeza dos fenômenos da cidade contribui para o aprendizado de forma dinâmica, pois possibilita a relação entre os conteúdos ministrados nas 
salas de aula com os conhecimentos dos próprios alunos. Ao entender que a sociedade é parte permanente no ato de educar, o professor deve conduzir seus alunos e mediar os conhecimentos ensinados, na perspectiva de ir ao encontro do mundo vivido dos educandos. Isso pode começar, por exemplo, pela exploração dos espaços que rodeiam a escola, dos percursos casa-escola, entre outras possibilidades, que conduzam os alunos a perceber, conhecer, intervir e (re) criar a sua cidade.

Assim, a cidade abriga fenômenos geográficos, cotidianos e globais, que podem ser significados para a construção e sistematização dos conhecimentos geográficos, por meio das vivências e experiências com esses fenômenos, por parte dos alunos em seu cotidiano. O espaço que é vivido é, sem dúvida, uma forma de engajar os alunos na ação transformadora do seu espaço. Para Castellar (2009),

Estudar a cidade enquanto lugar de vivência exige conhecermos as histórias dos lugares, as condições em que se inserem, tanto do ponto de vista do quadro natural, quanto das condições sociais e políticas e das diferenciações culturais. Cada cidade apresenta marcas que lhe são características, mas cada cidade também responde a questões globais, externas a essa região, e que precisam ser consideradas tanto na perspectiva do global quanto na do local (p. 105).

As questões aqui cunhadas podem ser percebidas e observadas no próprio movimento da cidade, por meio de seus sujeitos. Contudo, para que compreender a lógica dos movimentos que são vivenciados e experimentados pelos alunos no seu espaço vivido? Consideramos que o entendimento dessa lógica, que deve ser conduzida pelos professores, permitirá ao aluno aproximar-se do exercício ativo da cidadania, no sentido de compreender que suas marcas são peculiares e globais ao mesmo tempo.

Nesse sentido, pretende-se entender como são construídos os conhecimentos geográficos nas práticas docentes dos professores de Geografia das escolas pesquisadas e como essas práticas são capazes ou não de conferir a significação dos conteúdos de Geografia por meio do próprio lugar/cidade dos alunos. 


\section{TRILHAS PERCORRIDAS: A CONSTRUÇÃO DE INFORMAÇÕES EMPÍRICAS}

Este capítulo tem o propósito de explicitar o percurso metodológico desta investigação científica. Ressaltamos a importância da pesquisa qualitativa nas questões afetas à área de educação. Em vista disso, serão explicados o contexto de produção das informações empíricas, bem como os procedimentos de análise dessas.

\subsection{METODOLOGIA: A PESQUISA QUALITATIVA}

Compreender os processos referentes ao ensino da Geografia, do ponto de vista de identificar a função dessa área do conhecimento na escolarização, vem sendo objeto de estudos e pesquisas na atualidade. Nesse contexto, assumem importância aquelas pesquisas que desencadeiam a necessidade de buscar como os significados são construídos pelos professores, em sua prática pedagógica. Tal intenção se torna viável por meio da pesquisa qualitativa, que possibilita a análise da percepção dos professores, no tocante aos significados que constroem por ocasião de suas aulas. Assim, e de acordo com Bauer e Gaskell (2002), esse tipo de pesquisa evita números, lida com interpretações das realidades sociais, na perspectiva de seus sujeitos.

Portanto, a pesquisa qualitativa é a opção metodológica desta investigação, cuja produção de informações empíricas será efetuada por meio de análise documental, entrevistas semiestruturadas e observação de aulas de Geografia, num contexto em que os sujeitos da pesquisa são os professores de Geografia, de duas escolas públicas, da cidade de Formosa Goiás.

De um modo geral pode-se afirmar que pesquisadores da área de educação interesse pela utilização de metodologias de cunho qualitativo. Para Ludke e Menga (2013) a pesquisa qualitativa considera: o ambiente natural como fonte direta dos dados, que são predominantemente descritivos; a preocupação com o processo é muito maior do que o produto; os significados que as pessoas dão às coisas e a sua vida são focos de atenção; a análise dos dados tende a seguir um processo indutivo. A esse respeito Bogdan e Biklen 
(1994) destacam que esse tipo de pesquisa evidencia uma metodologia de investigação que enfatiza a descrição, a indução, a teoria fundamentada e o estudo das percepções pessoais dos sujeitos pesquisados.

A pesquisa educacional adquire relevância, na medida em que visa explicar e conhecer os fenômenos educacionais por meio de determinados procedimentos científicos. Por conseguinte, contribuem para as análises referentes ao processo de ensino-aprendizagem.

Por isto, para a presente investigação, devem ser compreendidos os significados produzidos pelos professores de Geografia, no contexto de suas práticas docentes, no intuito de identificar o papel dessa disciplina no processo de escolarização. Para isso, tornam-se necessárias a adoção de alguns procedimentos, cuja explicitação encontra-se a seguir.

\subsection{O CONTEXTO DE CONSTRUÇÃO DE INFORMAÇÕES EMPÍRICAS}

Nesta seção será apresentado o contexto no qual são construídas as informações empíricas que embasam esta investigação. Nesse sentido, serão explicitados o lugar da pesquisa - o município de Formosa, as escolas onde foram construídas aquelas informações, e os participantes da pesquisa, os professores de Geografia das escolas em questão.

É importante ressaltar, que a escolha da cidade de Formosa enquanto lugar é decorrente da experiência do pesquisador, que tem sua vivência cotidiana nesse local. $\mathrm{O}$ exercício do magistério, nessa cidade, permitiu a percepção de que os alunos e professores desconhecem, e muitas vezes não aproveitam, os fenômenos que ocorrem na comunidade, no sentido de utilizá-los para a construção de conhecimentos significativos referentes à prática espacial dos alunos, professores e da própria comunidade escolar.

\subsubsection{O município de Formosa/Goiás: breve explicitação desse lugar}

Na perspectiva da história da cidade, Magalhães e Eleutério (2008) destacam que o surgimento do povoado de Arraial dos couros decorreu da fuga de comunidades e de agricultores que residiam no Arraial de Santo Antônio, que era localizado nas mediações do 
rio Itiquira com o Paranã. Por causa da malária os moradores desse pequeno lugar tiveram que procurar nova morada.

Para Monti (2007), foi no século XVIII que se iniciou a história do município de Formosa. O território foi ocupado pelos bandeirantes, que buscavam pedras e metais preciosos, além de mão de obra indígena. Porém, foi a partir de 1830 que sua população começou a crescer e em 1843, o arraial foi elevado à condição de Vila e recebeu o nome de vila Formosa da Imperatriz, que, posteriormente, teve seu nome simplificado para Formosa. O autor evidencia, ainda, que a criação de Brasília foi um marco relevante para o crescimento da cidade. Novas rodovias foram construídas no município, o qual teve seu processo de desenvolvimento impulsionado. Nessa perspectiva, o município de Formosa começou a ter sua área de influência estendida para outros municípios do estado de Goiás.

Segundo os dados do Plano Diretor do município de Formosa (BRASIL, 2003), sua sede está localizada na latitude $15^{\circ} 32^{\prime} 14$ "S e longitude $47^{\circ} 20^{\prime} 04^{\prime \prime} \mathrm{W}$, com uma altitude média de $918 \mathrm{~m}$; possui uma área territorial de $5.811,788 \mathrm{~km}^{2}$, com cerca de 112.236 habitantes e uma densidade demográfica de $17,22 \mathrm{hab} / \mathrm{km}^{2}$ 92\% da população vive em área em área urbana e a população feminina é um pouco maior que a masculina, $50,1 \%$. Sua vegetação típica é o cerrado e, segundo a classificação de Koppen, apresenta clima tropical com um déficit hídrico no inverno e verão quente e úmido (IBGE, 2016).

O município faz parte da mesorregião do Leste goiano e da microrregião do Entorno do Distrito Federal (figura 2). A sede do município se localiza a 79 km da Capital Federal e a 280 km de Goiânia, capital do estado de Goiás (ARRAIS, 2011). 
Figura 2 - Localização da cidade de Formosa.
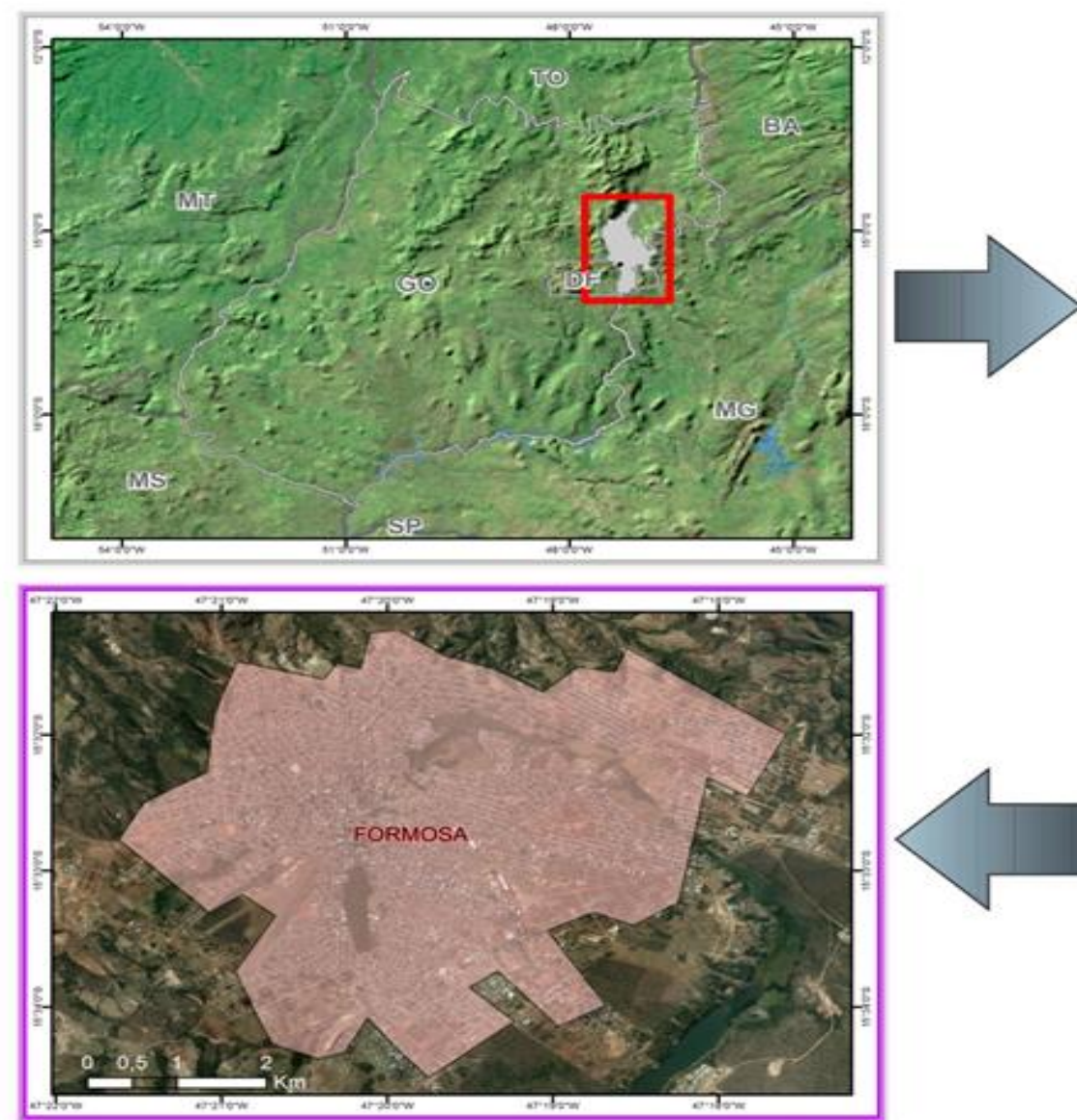

Legenda

5 Perimetro Urbano $\square$ Limite Municipal Formosa

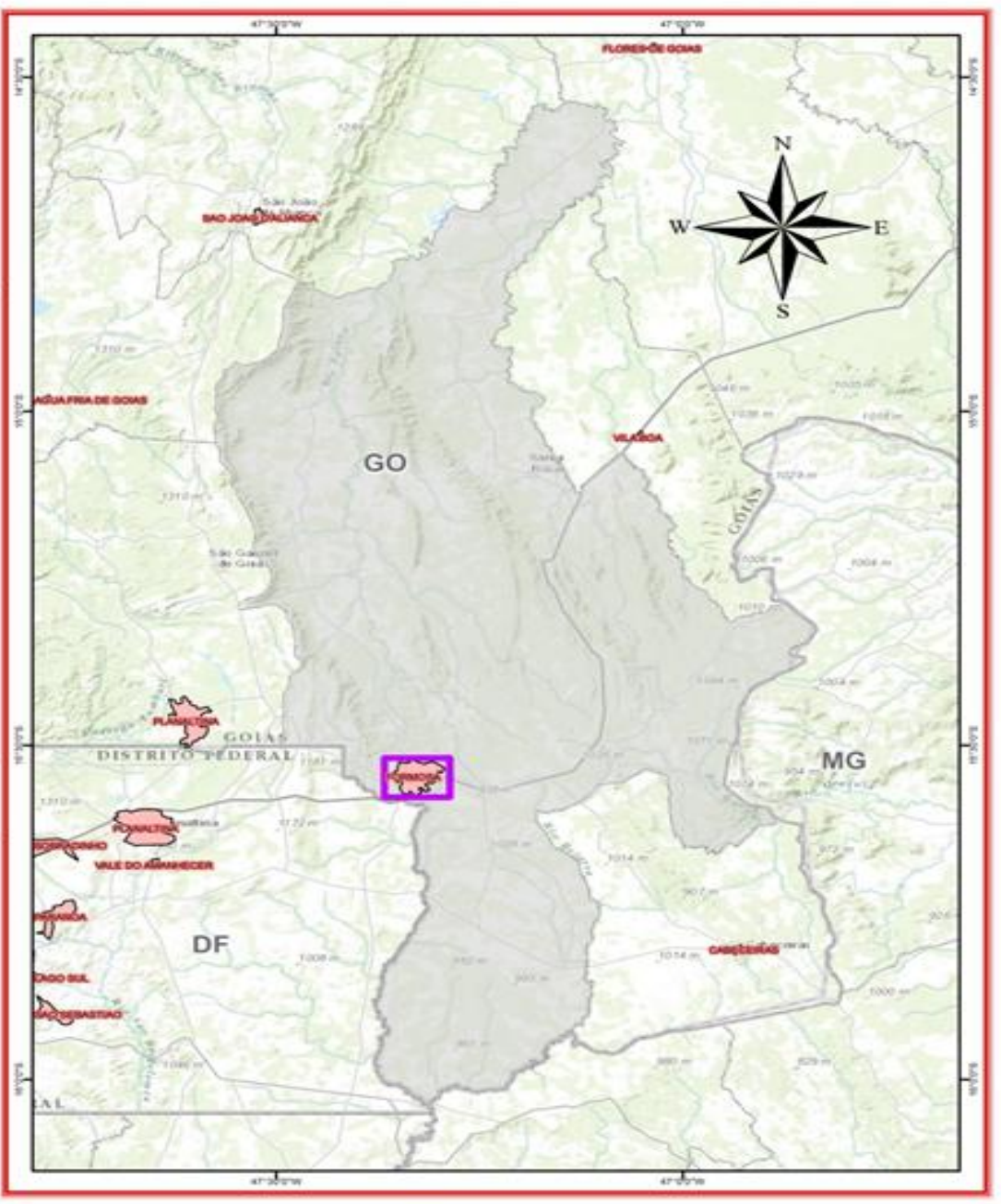

Fonte: Gomes, 2015. 
Em virtude da proximidade com o Distrito Federal (DF), a cidade convive com grande fluxo migratório, destacando-se a migração pendular, o que gera especulação imobiliária e, como é comum nessas situações, ocupação desordenada do território. O município integra a Região de Desenvolvimento Integrado do Distrito Federal e Entorno - RIDE (BRASIL; GOIÁS; FORMOSA, 2003).

Sua economia é predominantemente voltada ao setor de serviços. O Índice de Desenvolvimento Humano Municipal (IDHM) do ano 2010 é de 0, 744, considerado de médio desenvolvimento humano, segundo o Atlas de Desenvolvimento Humano (PNUDBRASIL, 2013). No que se refere aos fatores do IDHM, educação, expectativa de vida e renda, o município possui um indicador de 0,852 .

Nas últimas décadas assinalou o crescimento populacional da cidade, o que desencadeou grande especulação imobiliária e, em consequência, nova distribuição espacial. Se compararmos os dados do ano de 1991 até 2010, período do último censo demográfico constataremos que o crescimento da população foi de $58,8 \%$, ou seja, $3,3 \%$ ao ano. Assim, a população passou de 62, 982 habitantes em 1991, para mais de 100.000 habitantes em 2010 chegando a 112.236 habitantes no presente ano (IBGE, 2016).

Silva (2011) destaca que as questões urbanas de Formosa são complexas, na medida em que não se vincula somente com os processos de modernização do campo. Nesse sentido, a cidade faz parte de uma rede de municípios marcados por movimentos migratórios pendulares com destino a Brasília, o que aponta a complexidade da análise desse espaço geográfico.

$\mathrm{O}$ crescimento da cidade e o surgimento de vários bairros (figura 3) evidenciam a complexidade de ações e objetos na configuração territorial da cidade, que se constitui um lugar de interações e movimentos em constante processo de transformação. 
Figura 3 - Perímetro urbano de Formosa, GO.
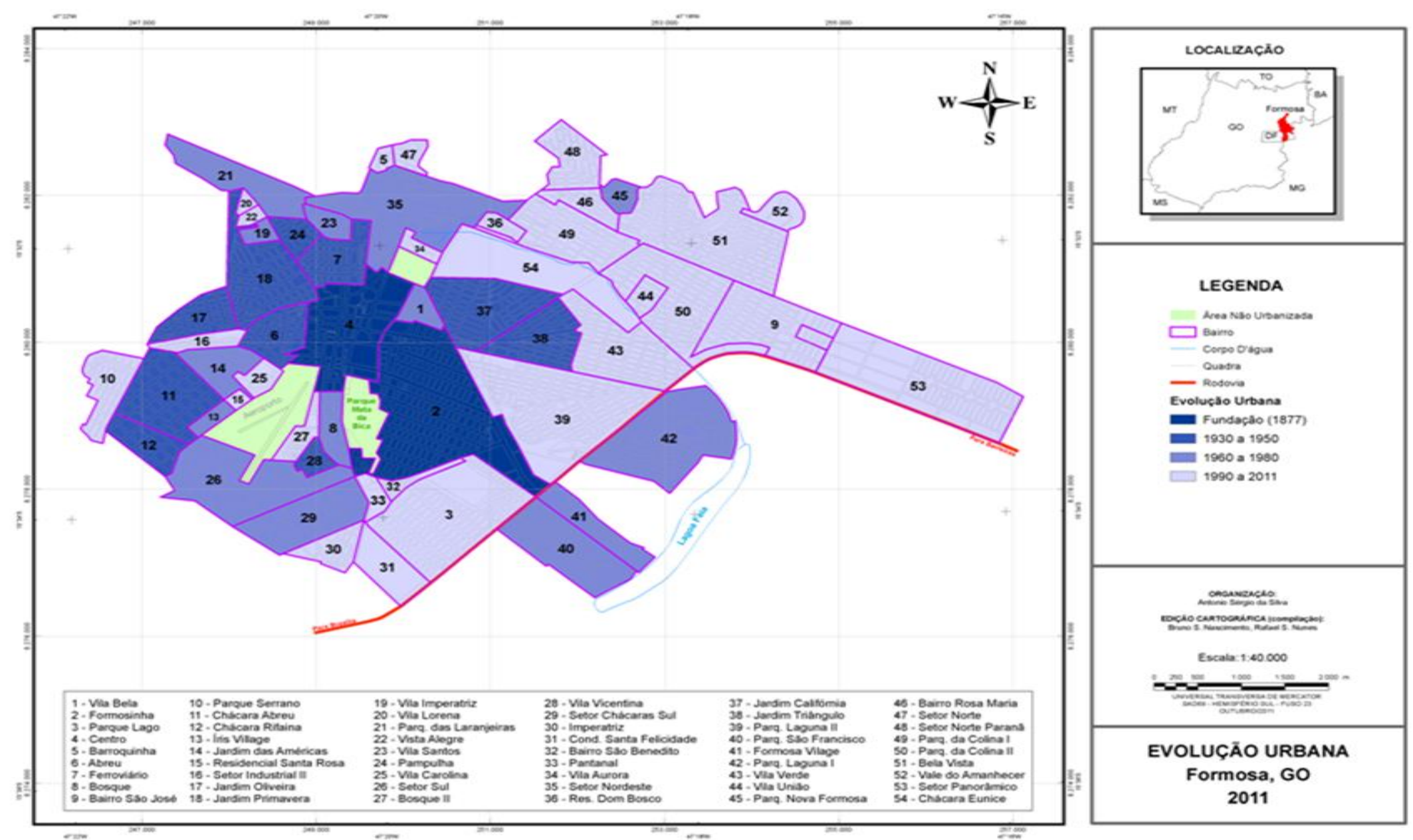

Fonte: SILVA, 2011. 
A cobertura vegetal original é o cerrado brasileiro, marcada por fitofisionomias, tais como: Cerrado ralo, Campo Sujo e manchas de Cerrado Denso (VIEIRA, 2010). Sabe-se que essa vegetação vem sendo agredida pela ação antrópica, com marco de destruição decorrente da construção de Brasília e, na atualidade, em virtude da expansão da agricultura mecanizada

Em relação à educação, Formosa conta com uma rede escolar consolidada (escolas municipais, estaduais e privadas), um Instituto Federal de Educação e um câmpus da Universidade Estadual de Goiás. Na rede pública de ensino referente à Educação Básica, existem 1.083 professores, 754 salas de aula em 81 estabelecimentos de ensino. No ano de 2012 constava-se um total de 20.363 alunos matriculados na Educação Básica, onde desse total cerca de 70\% encontram-se no Ensino Fundamental (INEP, 2013).

Após as considerações acerca de aspectos gerais da cidade, tem-se a necessidade de destacar alguns encaminhamentos no que se refere à utilização do Lugar/Formosa por meio da categoria em pauta, para mediar os conhecimentos geográficos. De tal modo, destacam-se alguns exemplos que podem ser utilizados pelos professores, em suas práticas, para construir com os alunos um ensino significativo e relacioná-lo com a totalidade, visto que os conceitos devem ser mediados com aspectos da vida cotidiana, em sua própria cidade. Assim, nessa perspectiva se inserem a Mata da Bica, Salto do Itiquira, Toca da Onça, Buraco das Araras, os lagos do Vovô, da Vovó, do Abreu e dos Santos, Lagoa e o córrego Josefa Gomes.

A Mata da Bica (figura 4) é reserva natural no centro da cidade. Possui uma rica fauna e flora, em volta de sua nascente, o que se constitui numa ferramenta para promoção da consciência ambiental ou ecológica ${ }^{5}$, para e a valorização do patrimônio natural, notadamente aquele que se mantém no perímetro urbano da cidade. Nesse espaço que é vivenciado pelos alunos da cidade encontra-se uma possibilidade de construção de conhecimentos geográficos, a partir de elementos, tais como, vegetação do cerrado, mata de galeria e ciliar, nascente, erosão fluvial, entre outros.

No município existem, também, pontos turísticos, que podem ser utilizados no contexto da conservação ambiental. Entre esses se destacam: Salto do Itiquira, Toca da Onça, Buraco das Araras, os lagos urbanos (Lago do Vovô, Lago da Vovó, Lago do Abreu e Lagoa dos Santos) e a Lagoa Feia, que podem servir de parâmetro de comparação ou ponto de partida para mediara construção de conceitos e conhecimentos em Geografia, visto que os

\footnotetext{
${ }^{5} \mathrm{~A}$ questão ambiental é um conteúdo a ser trabalhado no capítulo 16 do livro didático analisado nesta pesquisa.
} 
alunos os conhecem e, por conseguinte, podem fazer relações com fenômenos geográficos, que se repetem em escala local-global. Nessa perspectiva, por exemplo, podem ser considerados os conceitos de degradação ambiental, meio ambiente, desenvolvimento sustentável, entre outros. Assim, pode ser despertado, ainda, o espírito de cidadania desses alunos, porque sua aproximação com a natureza, que viabiliza uma compreensão acerca dos conceitos relativos à sua própria dinâmica, bem como aos processos de recuperação, preservação e conservação ambiental, podem desencadear uma sensibilização às condutas consideradas ambientalmente adequadas e, por conseguinte, cidadã. 
Figura 4 - Lugar/Formosa: exemplos de espaços conhecidos pelos alunos que podem ser convergidos ao processo de ensino/aprendizagem.

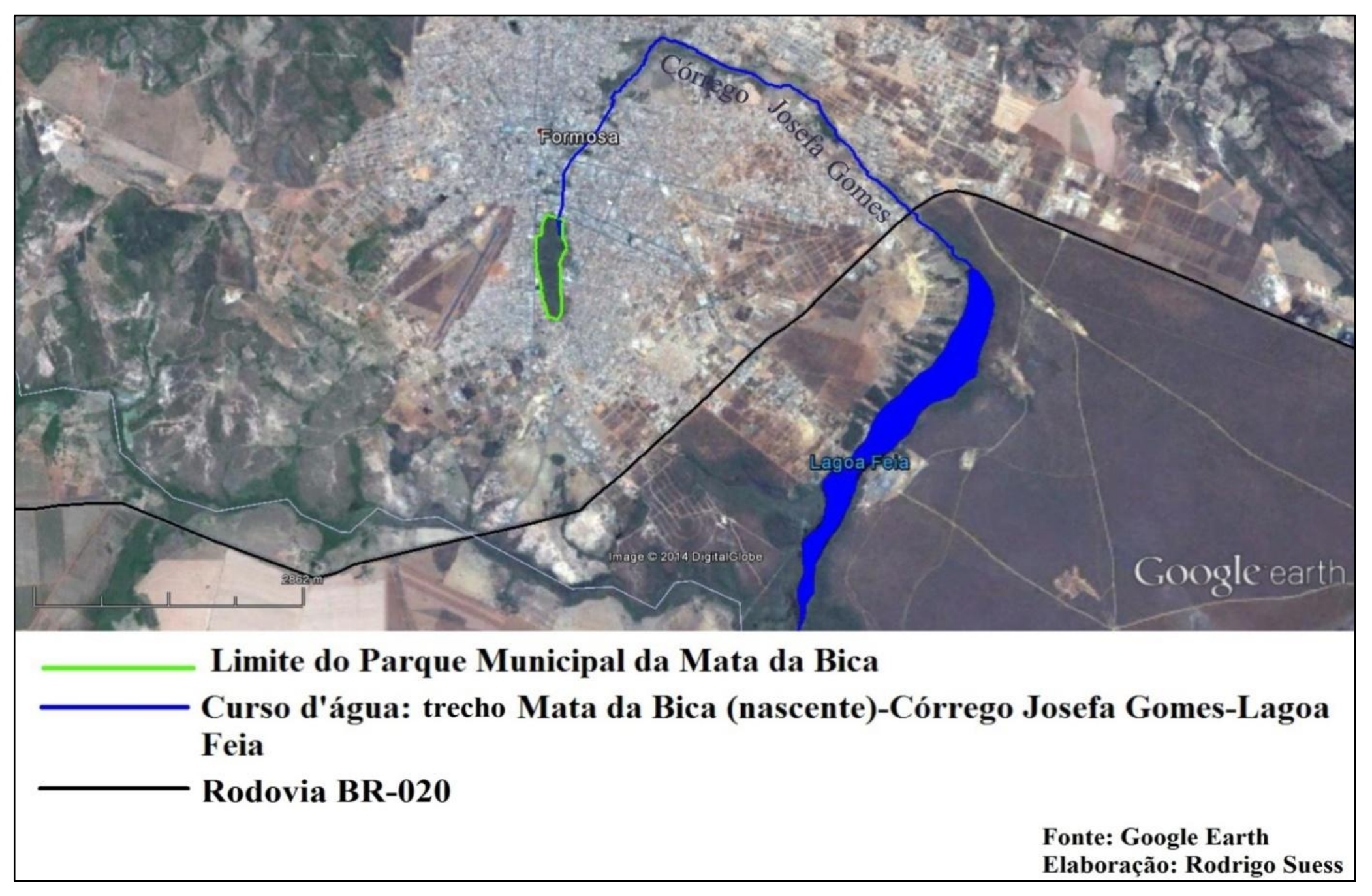

Organização: SUESS, 2014. 
O córrego Josefa Gomes, que percorre uma expressiva parte da área urbana da cidade, possui sua nascente no Parque Municipal da Mata da Bica e deságua na Lagoa Feia. Ambos são considerados pontos turísticos de Formosa e constituem-se possibilidades concretas para se analisar as questões ambientais e urbanas da cidade, além de permitir a sistematização de alguns conceitos, abstratos aos alunos, tais como nascente, jusante, montante, assoreamento, rede hidrográfica, entre outros.

Tais possibilidades apresentam o potencial de favorecer o trabalho do professor no tocante à identificação do processo de expansão urbana e nesse contexto, o crescimento da construção civil na cidade e seu o impacto no córrego e arredores, a criação de conjuntos habitacionais no decorrer do curso d'água (direito social da moradia x direito ambiental), a falta de respeito com as Áreas de Proteção Permanente (APP), o processo de assoreamento e eutrofização do córrego e suas consequências ambientais, acúmulo de lixo e a proliferação de patógenos, entre outras questões, de caráter geográfico, que podem ser constatadas in loco ou por meio de pesquisas propostas pelos professores, considerando o lugar como via de mediação pedagógica para a construção desses conceitos.

Além disso, os casarões históricos, o Museu Couros, o centro da cidade e sua periferia, as festas religiosas, a feira agropecuária, a área rural, os assentamentos rurais, a rodovia BR 020, principal eixo de articulação rodoviário da cidade, constituem-se ocorrências concretas na vida do lugar Formosa e, por isso, devem ser considerados na abordagem dos conteúdos de Geografia. 
Figura 5 - Lugares de Formosa: (A) Lago do Vovô; (B) A Rua Visconde Porto Seguro, localizada na área central da cidade; (C) Museu Couros e (D) Casarão Antigo.

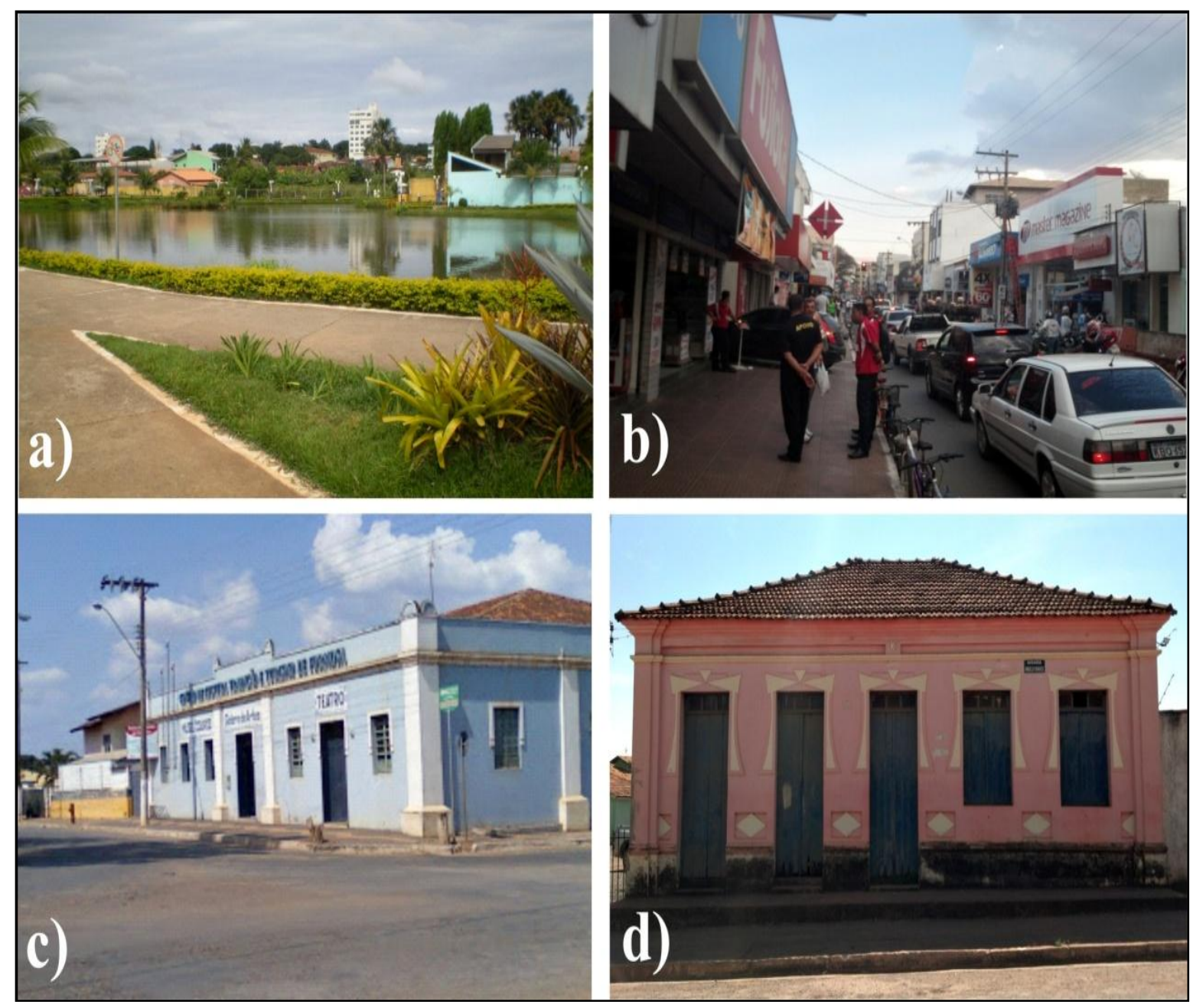

Organização: Carvalho Sobrinho, 2016.

A imagem acima evidencia lugares de Formosa, que apresentam inúmeras possibilidades de mediação: 5(a) o Lago do Vovô pode ser utilizado para discutir ações que fomentem, não somente, a educação ambiental, como também, permita compreender a teorização sobre o setor de serviços, por meio do lazer; a Rua Visconde Porto Seguro, figura 5(b), considerada centro, em virtude da concentração de lojas, bancos, filiais de empresas nacionais e multinacionais, fluxos de pessoas e mercadorias. O Museu dos Couros, figura 5(c), possibilita análises relacionadas à ocupação/produção do território regional, pela ótica formosense, por meio de seu histórico de formação, e exploração econômica ao longo do tempo. A figura 5(d), padrão de habitação tradicional, atesta as permanências e rugosidades do espaço geográfico da cidade. Nesse sentido, todos possibilitam abordagem de temas 
variados relacionados aos conteúdos geográficos, a partir de elementos, concretos, vividos e conhecidos dos alunos.

Há de se considerar, ainda, a dimensão do lugar para se compreender o mundo, como propõe Callai (2000). Nessa perspectiva, é importante identificar como se dá o processo de articulação da cidade, com a região, o país, o mundo. Em consequência, a construção dos conhecimentos relativos ao conteúdo sobre globalização adquire maior concretude. Nessa linha de raciocínio, e de se transpor/articular o local ao global, a cidade de Formosa pode ser considerada para que os alunos compreendam assuntos relacionados à demografia, bem como algumas de suas consequências, relacionadas à geração de pobreza, fome e exclusão $\operatorname{social}^{6} \mathrm{e} o$ próprio Índice de Desenvolvimento Humana $^{7}$ (IDH), importante identificador para avaliar o desenvolvimento social e distribuição de renda dos países, regiões, cidades, que pode ser analisado a partir do Índice de Desenvolvimento Humano Municipal (IDHM) de Formosa. Assim, os alunos podem (re)significar os conteúdos por sua aplicação ao seu espaço vivido.

Tais temáticas correspondem aos conteúdos abordados nos livros didáticos do $9^{\circ}$ ano do Ensino Fundamental e enunciam um elenco de oportunidades para os processos de mediação didática e pedagógica, associadas à construção do saber geográfico a partir do lugar. Nesse sentido, representa alguns exemplos como sugestão de trabalho aos professores, para compreensão e construção dos conhecimentos geográficos, a partir da realidade vivida no lugar/Formosa. É nesse contexto que são construídos os significados produzidos em sala de aula: um espaço que foi alterado ao longo do tempo, apropriado seletivamente, mas percorrido cotidianamente por todos que aí vivem.

\subsubsection{As escolas alvos da pesquisa ${ }^{8}$}

Inicialmente, torna-se importante ratificar, que a opção em realizar a pesquisa em escolas públicas está relacionada ao grande número de alunos da Educação Básica matriculados nessas escolas e, também, por perceber que essas merecem atenção dos pesquisadores. Destacamos ainda, que a escola representa um lugar de encontro de saberes,

\footnotetext{
${ }^{6}$ Pobreza, fome e exclusão social, conteúdo a ser trabalhado no capítulo 11 do livro didático analisado.

${ }^{7} \mathrm{O}$ Índice de Desenvolvimento Humano (IDH) é um conteúdo a ser trabalhado no capítulo 8 do livro didático analisado.

${ }^{8}$ Destacamos que as informações relativas à caracterização das escolas no que se refere histórico, estruturas físicas e organizacionais foram coletadas por meio da pesquisa exploratória com o roteiro de caracterização que se encontra no apêndice $\mathrm{A}$.
} 
lugar de cultura, de contradições, logo, a categoria lugar se apresenta importante nesse contexto. Porém, neste momento daremos enfoque somente nas questões relacionadas ao histórico, organização física e administrativa.

Para a presente investigação foram escolhidas escolas da cidade de Formosa - Goiás. O intuito foi contemplar instituições escolares que possuem dinâmicas e características distintas. Assim, optou-se por duas escolas: uma na área mais nobre da cidade - Escola B - e outra na periferia - Escola A (figura 6). 
Figura 6 - Localização das escolas pesquisadas.

\section{Localização das escolas pesquisadas na cidade de Formosa/GO, 2016.}

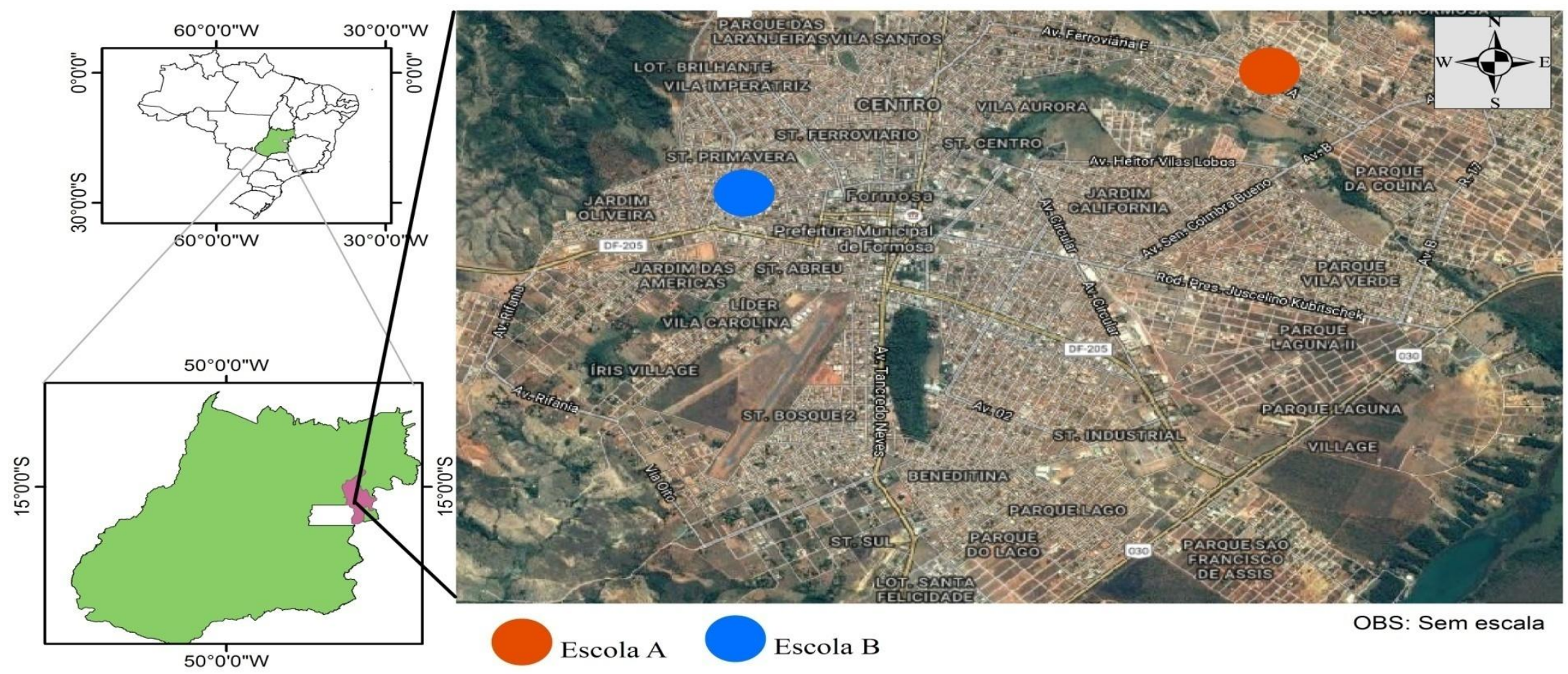

Base: IBGE 2007, Organização, SILVA, Rosinaldo Barbosa, outurbo de 2016.

Organização: SILVA, 2016 
Tal opção foi decorrente de pesquisa exploratória, por meio de visitas, onde foram efetuadas observações, conversas informais com secretários, professores e diretores, no intuito de obter um panorama geral das escolas - histórico, estrutura física, quantitativo de alunos e servidores, entre outros - e a partir daí, selecionar aquelas onde seriam construídas as informações empíricas desta pesquisa.

As visitas aconteceram no mês de Fevereiro de 2016, no período matutino. Nesse contexto, ocorreram algumas dificuldades na escolha das escolas, pois como evidenciou Carvalho Sobrinho (2014) $)^{9}$, uma parte significativa dos professores que ministram a disciplina de Geografia, na cidade de Formosa, não são formados na área. Tal fato constitui-se, efetivamente, um fator complicador do processo de ensino-aprendizagem dessa área e se traduziu em um elemento determinante na escolha das escolas, ou seja: foi a partir do critério "dispor de professores de Geografia formados em Geografia", que foram selecionadas as duas escolas em questão.

Nas subseções a seguir, serão apresentadas as características gerais das escolas pesquisadas. Para preservar sua identidade, optou-se por utilizar nomes fictícios. Assim, a Escola A é aquela localizada na periferia de Formosa e Escola B a da área central.

\subsubsection{Escola A: histórico, estrutura física e organizacional}

Segundo a direção da unidade escolar a Escola A foi construída pelo Lions Clube de Formosa, e sua inauguração ocorreu no ano de 1977. Localiza-se em setor considerado periférico, em relação ao sítio urbano da cidade.

A escola atende um total de 713 alunos entre a Educação Infantil, Ensino Fundamental anos iniciais e finais, além de ofertar, no período noturno, a Educação de Jovens e Adultos (EJA). A escola dispõe de melhor estrutura física, quando comparada com a outra escola pesquisada (no centro da cidade), pois passou, recentemente, por uma reforma geral na estrutura do prédio.

\footnotetext{
${ }^{9}$ Trabalho de conclusão de curso intitulado - A categoria lugar no livro didático de Geografia: abordagens e contribuições no processo de ensino/aprendizagem - apresentado na Universidade Estadual de Goiás no ano de 2014. O autor identifica que significativa parcela dos professores que ministram aulas de Geografia na cidade de Formosa - Goiás não possui habilitação específica nessa disciplina.
} 
Quadro 1-Organização do ambiente físico da Escola A.

\begin{tabular}{|l|c|}
\hline \multicolumn{1}{|c|}{ Dependências } & $\mathbf{N}^{\mathbf{0}}$ \\
\hline \multicolumn{1}{|c|}{ Térreo } & 01 \\
\hline Secretaria & 01 \\
\hline Diretoria & 01 \\
\hline Sala da Psicóloga/ Psicopedagoga & 01 \\
\hline Sala de Professor & 01 \\
\hline Coordenação & 01 \\
\hline Biblioteca & 01 \\
\hline Laboratório de Informática & 03 \\
\hline Banheiro Administrativo & 01 \\
\hline Área de circulação & 01 \\
\hline Cantina & 01 \\
\hline Área de serviço & 01 \\
\hline Depósito de Materiais pedagógico-didáticos & 01 \\
\hline Depósito de merenda & 04 \\
\hline Salas de aula & 06 \\
\hline Banheiro feminino & 04 \\
\hline Banheiro masculino & 01 \\
\hline Quadra coberta & 01 \\
\hline Sala de recursos & \\
\hline & 08 \\
\hline Salas de aula & 04 \\
\hline Banheiro feminino & 04 \\
\hline Banheiro masculino & 01 \\
\hline Área de circulação & 02 \\
\hline Área de serviço & \\
\hline
\end{tabular}

Fonte: Projeto Político Pedagógico, 2016.

Atualmente a escola possui 43 servidores, distribuídos entre secretária, auxiliares de serviços gerais, coordenadores, direção e 26 professores.

\subsubsection{Escola B: histórico, estrutura física e organizacional}

A escola localiza-se na área central do sítio urbano da cidade de Formosa. A instituição foi criada como uma escola da iniciativa privada, filantrópica, que pertencia a Igreja Presbiteriana, sendo extinta em 2001. Entretanto, por causa da grande demanda da rede 
pública de ensino, a escola foi assumida pela rede municipal, o que melhorou sua estrutura física. Posteriormente, teve uma nova sede construída (FORMOSA, 2016).

A escola atende um total de 900 alunos entre a Educação Infantil, Ensino Fundamental anos iniciais e finais, além de ser um dos pólos na oferta da EJA e Ensino Especial da cidade. Possui uma estrutura razoável, se apresenta em bom estado para realização de práticas pedagógicas diversas.

Quadro 2 - Organização do ambiente físico da Escola B.

\begin{tabular}{|l|c|}
\hline \multicolumn{1}{|c|}{ Dependências } & $\mathbf{N}^{\mathbf{0}}$ \\
\hline \multicolumn{1}{|c|}{ Térreo } & 01 \\
\hline Secretaria & 01 \\
\hline Diretoria & 01 \\
\hline Sala da Psicóloga/ Psicopedagoga & 01 \\
\hline Sala de Professor & 01 \\
\hline Coordenação & 01 \\
\hline Biblioteca & 01 \\
\hline Laboratório de Informática & 03 \\
\hline Banheiro Administrativo & 01 \\
\hline Área de circulação & 01 \\
\hline Cantina & 01 \\
\hline Área de serviço & 01 \\
\hline Depósito de Materiais pedagógico-didáticos & 01 \\
\hline Depósito de merenda & 06 \\
\hline Salas de aula & 05 \\
\hline Banheiro feminino & 05 \\
\hline Banheiro masculino & 01 \\
\hline Quadra coberta & 01 \\
\hline Sala de recursos & \\
\hline & 06 \\
\hline Salas de aula & 01 \\
\hline Área de circulação & 02 \\
\hline Área de serviço & 01 \\
\hline Laboratório de Informática & \\
\hline
\end{tabular}

Fonte: Projeto Político Pedagógico, 2016.

A organização administrativa da escola é a seguinte: 1 diretor, 1 vice-diretor, 1 secretário, 1 auxiliar de secretaria, 2 coordenadores pedagógicos; 38 professores, 7 auxiliares 
de serviços gerais, 1 supervisor de merenda e 2 vigias. A escola se encontra em bom estado de conservação, pois passou, recentemente, por reforma.

\subsubsection{Os sujeitos da pesquisa: os professores de Geografia das escolas pesquisadas}

Salientamos que, para fins desta pesquisa, analisamos a prática pedagógica de dois professores do $9^{\circ}$ ano do Ensino Fundamental. A opção desse respectivo ano se justifica por ser o último do Ensino Fundamental, pois o lugar não se constitui conteúdo curricular formal das aulas de Geografia, nessa etapa de escolarização. Assim, pretende-se identificar se o professor o utiliza como via de mediação pedagógica, como nos exemplos apontados anteriormente.

A escolha de trabalhar com professores se vincula ao objetivo geral desta pesquisa, pois a construção de conhecimentos geográficos, por meio de um ensino significativo em Geografia, que valorize o lugar, perpassa pela atuação do professor em sala de aula.

Quadro 3- Caracterização dos participantes da pesquisa

\begin{tabular}{|c|l|c|c|c|}
\hline $\begin{array}{c}\text { Especificaçã } \\
\text { o e escola }\end{array}$ & Formação & Local de moradia & Situação funcional & $\begin{array}{c}\text { Tempo de } \\
\text { experiência na } \\
\text { escola }\end{array}$ \\
\hline $\begin{array}{c}\text { Professor A } \\
\text { (Escola A) }\end{array}$ & $\begin{array}{l}\text { - Geografia } \\
\text { - Especialização }\end{array}$ & Formosa & Efetivo & 1 ano \\
\hline $\begin{array}{c}\text { Professor B } \\
\text { (Escola B) }\end{array}$ & $\begin{array}{l}\text { - Geografia } \\
\text { - Especialização }\end{array}$ & Formosa & Efetivo & 5 anos e 7 meses \\
\hline
\end{tabular}

Organização: Carvalho Sobrinho, 2016.

Pode-se observar que os professores são formados na disciplina em que atuam, possuem pós-graduação em nível de especialização, são efetivos na Secretaria Municipal de Educação (SME), com lotação definitiva nas escolas, o que contribui para um trabalho pedagógico contínuo e moradores da cidade de Formosa.

A rotina dos professores, no que se refere aos trabalhos que realizam no cotidiano escolar, é definida por um calendário aprovado pela Secretaria Municipal de Educação (SME) e pelo Conselho Municipal de Educação (CME), após passar por consulta pública e dialogada 
com os professores e, também, representantes sindicais. As atividades laborais de ambos os professores segue a mesma dinâmica: aulas no turno matutino das 07h30min às $12 \mathrm{~h} 30 \mathrm{~min}$ com carga horária semanal de 30 horas.

\subsection{PROCEDIMENTOS PARA A CONSTRUÇÃO E ANÁLISE DAS INFORMAÇÕES EMPÍRICAS}

Neste momento enfatizaremos os procedimentos para a construção de informações empíricas, a saber: análise documental do Plano de Ensino, do Projeto Político Pedagógico das escolas participantes e dos livros didáticos usados pelos professores; entrevistas com professores de Geografia das escolas pesquisadas, abaixo explicitados.

\subsubsection{Análise documental: PPPs, PE e LDs}

A análise documental integra o rol de procedimentos a serem adotados, para a construção da base de informações empíricas desta pesquisa. Embora pouco utilizada na área educacional, essa alternativa se constitui como importante via de pesquisa. Nesse sentido, e de acordo com Phillips (1974), a análise de documentos ou quaisquer materiais escritos caracteriza a análise documental, que pode incluir: regulamentos, pareceres, cartas, memorandos, diários de pessoas, jornais, revistas, discursos, entre outros. Os documentos constituem como uma fonte poderosa, de onde podem ser retiradas evidências, que fundamentam afirmações e declarações (LUDKE; MENGA, 2013).

Desse modo, o Projeto Político Pedagógico das escolas participantes, o Plano de Ensino e os livros didáticos (LDs) compõem o acervo documental a ser usado nesta pesquisa, por conter elementos que permitam elucidar a prática pedagógica dos professores participantes.

Os documentos selecionados para análise serão lidos e estudados com o enfoque orientado à identificação da categoria lugar. Optamos por analisar cada documento de forma separada, para identificar abordagens diferenciadas. Destarte, de forma sistemática, os documentos foram analisados na seguinte lógica hierárquica: os PPPs, PE e os LDs. Desse 
modo, foram realizadas leituras completas dos documentos, para identificar seus debates e suas orientações relacionados aos objetivos desta pesquisa.

O PPP se refere a um documento que organiza as atividades pedagógicas de uma escola, com especificação das perspectivas assumidas pela comunidade escolar, onde cada contexto e realidade são valorizados, inclusive o lugar. Por conseguinte, o PPP norteia o trabalho pedagógico, por encaminhar ações futuras, com base na realidade que é vivenciada pelos sujeitos da escola.

Como procedimento de análise desse documento, realizamos uma sistematização das informações contidas nos referidos documentos, por meio da construção de uma matriz analítica, pautada pelas seguintes variáveis: concepção de ensino/aprendizagem; expectativa de aprendizagem; projetos desenvolvidos que consideram o Lugar/Formosa.

Os Planos de Ensino se caracterizam como um documento que anuncia a intenção da prática docente para um semestre ou mesmo o ano letivo, por meio de objetivos específicos, conteúdos e procedimentos metodológicos (LIBÂNEO, 1994). Este documento foi analisado na perspectiva de perceber uma relação entre conteúdos e utilização do lugar, nos desenvolvimentos metodológicos adotados no contexto dessa disciplina.

O processo de ensino aprendizagem em Geografia, na Educação Básica, utiliza os LDs como principal recurso pedagógico na mediação dos conhecimentos escolares. Para Tonini (2011), todos os dias, nas mais diferenciadas partes do mundo, os alunos entram em sala de aula portando livros didáticos. Esses, presentes na vida educacional dos alunos, desde os primeiros anos de escolarização até os últimos, têm a função de auxiliar no desenvolvimento das ações pedagógicas, que são implementadas pelos professores. Deste modo, se torna um documento (instrumento) importante de ser analisado na perspectiva do lugar.

No que se refere à análise do LD utilizado pelos professores, elencamos alguns critérios para a análise do lugar nesse importante recurso pedagógico (SOUZA, 2012; CARVALHO SOBRINHO, 2014):

1. Apresentação geral do livro a ser analisado (capa, páginas, autor/autores, editora, ano de edição).

2. Análises das ilustrações, imagens, representações cartográficas, gráficos, quadros e tabelas. 
3. Fidedignidade de informações e ausência ou presença de preconceitos;

4. Identificação de estímulo à observação, investigação, análise, síntese, criatividade e interpretação, entre outros, que se relaciona com o lugar;

5. Análise das atividades, no sentido de identificação das possibilidades de desenvolvimento de competências e habilidades por meio do lugar;

6. Tratamento da categoria lugar ao longo do livro.

\subsubsection{Entrevistas semiestruturadas com os docentes pesquisados}

Outro procedimento adotado refere-se à entrevista. Essa se constitui um instrumento basilar para a produção de informações empíricas em uma perspectiva qualitativa. Além do mais, é um dos principais métodos adotados por pesquisadores das ciências sociais, por permitir uma interação entre o pesquisador e os participantes da pesquisa (RICHARDSON, 2014).

Portanto, por meio desse procedimento foi possível a obtenção das seguintes informações: percurso de formação do professor; compreensão acerca da Geografia Escolar; metodologias e instrumentos utilizados nas aulas de Geografia; relação com o Lugar/Formosa; perspectivas em relação à prática pedagógica: aspectos implícitos do cotidiano escolar.

Este caminho metodológico visa ir ao encontro das pessoas, para captar fenômenos que necessitam ser explicados. É um diálogo, uma troca de experiências e sentidos, que produz conhecimento sobre determinado objeto a ser estudado. Assim, deve ser realizada de forma adequada e planejada, sendo analisada e interpretada pelo pesquisador, para gerar conhecimentos coerentes e coesos que se aproximem, o mais perto possível, da realidade a ser estudada:

Toda pesquisa com entrevistas é um processo social, uma interação ou um empreendedorismo cooperativo, em que as palavras são o meio principal de troca. Não é apenas um processo de informação de mão única passado de um para o outro. Ao contrário, ela é uma interação, uma troca de ideias e de significados, em que varias realidades e percepções são exploradas e desenvolvidas (BAUER; GASKELL, 2002, p. 73).

Para Vergara (2009) as entrevistas estão permeadas por situações sociais complexas, por representar e manifestar uma teia de elementos a serem analisados pelo pesquisador, onde 
terá aspectos objetivos e subjetivos a serem captados. Nesse sentido, as entrevistas serão realizadas com os professores, e contribuirá para o alcance do objetivo geral dessa investigação científica, qual seja, analisar o processo de construção de conhecimentos geográficos por meio da categoria lugar na prática pedagógica do professor de Geografia.

As entrevistas foram gravadas e posteriormente transcritas e analisadas. $\mathrm{O}$ ambiente das entrevistas foi o escolar, que possibilitou um clima mais favorável para dialogar assuntos voltados para questão educacional. Além disso, os dias das entrevistas foram registrados no diário do pesquisador e assinados pelos professores, para legitimar o processo de concordância da cessão de informações.

Assim, as entrevistas com os professores foram realizadas três encontros de 30 a 50 minutos cada, a partir das seguintes questões, por encontro:

- Primeiro encontro - Por qual razão você escolheu o curso de Geografia?; Qual eram as disciplinas preferidas nessa Graduação?; Conte um pouco da sua experiência como professor a de Geografia na cidade de Formosa; Quais são as principais dificuldades encontradas no exercício do seu magistério.

- Segundo encontro - Que importância você atribui ao ensino de Geografia?; Como você avalia a situação do ensino da Geografia em Formosa e no Brasil na atualidade?; Como você trabalha as aulas de Geografia: especificar?; Quais são os problemas que você identifica na sua prática pedagógica?

- Terceiro encontro Quais são os conteúdos de Geografia do $9^{\circ}$ ano que você ministra?; Como você trabalha esses conteúdos de Geografia? Especificar?; Quais são os problemas que você identifica na sua prática pedagógica ao trabalhar esses conteúdos?

Após a realização das entrevistas, foram efetuadas as transcrições dessas e as leituras e releituras de cada momento registrado, tendo como objetivo a captação de elementos significativos para análises, com sistematização das informações por meio de tabelas relacionadas aos objetivos da pesquisa.

Por fim, destacamos que esse procedimento é vantajoso para a referida pesquisa, por captar, de forma imediata, as informações necessárias do contexto escolar em que estão envolvidos os sujeitos, dando credibilidade para análises mais reflexivas e críticas, com o objetivo de pensar em possibilidades de construir uma Geografia mais significativa. 


\subsubsection{Instrumentos e materiais}

O processo de construção de informações empíricas demandará os seguintes instrumentos e materiais:

○ Cópias impressas do roteiro para as entrevistas semiestruturadas;

- Cópias impressas do roteiro para caracterização das escolas pesquisadas;

○ Gravador digital;

○ Caneta esferográfica;

○ Máquina fotográfica. 


\section{RESULTADOS E DISCUSSÕES: OBSTÁCULOS E PERSPECTIVAS PARA A CONSTRUÇÃO DOS CONHECIMENTOS GEOGRÁFICOS POR MEIO DA CATEGORIA LUGAR}

\subsection{RESULTADOS E DISCUSSÕES}

Os resultados e as discussões desta pesquisa se apresentam divididos em duas seções: análise documental e entrevistas. Os resultados serão apresentados por meio de quadros, que sistematizam as informações empíricas construídas. É importante esclarecer que a sistematização foi efetuada tendo como foco a categoria lugar na construção da aprendizagem em Geografia, conforme explicitado anteriormente. Esse procedimento constitui-se um interessante recurso de análise.

\subsubsection{Análise documental}

Optou-se por analisar de forma separada cada documento para identificar as questões que estão imbricadas à categoria central desta pesquisa. Esse processo conduz a uma organização e compreensão mais abrangente das informações abstraídas. Os resultados e a análise documental obedecem a seguinte lógica hierárquica: PPPs, PE e LD.

Os documentos utilizados foram analisados à luz do objetivo geral desta pesquisa, que é analisar o processo de construção de conhecimentos geográficos por meio da categoria lugar na prática pedagógica do professor de Geografia, e, ainda, dos objetivos específicos relativos a esse procedimento metodológico que são:

- Verificar e analisar como o Lugar/Formosa é considerado no PPP das escolas;

- Identificar e analisar como os Planos de Ensino utilizam o Lugar/Formosa;

- Analisar a abordagem do lugar no Livro Didático utilizado.

\subsubsection{Os PPPs das escolas pesquisadas}


Os resultados obtidos dos referidos documentos deram origem ao quadro 4, no qual o foco é perceber se o Lugar/Formosa é considerado. Nesse sentido, as informações contidas naqueles documentos foram sistematizadas em uma matriz, com base nos seguintes critérios: concepção/fundamentos de ensino/aprendizagem; expectativa de aprendizagens e projetos desenvolvidos que consideram o Lugar/Formosa.

Quadro 4 - Projetos Políticos Pedagógicos das escolas pesquisadas.

\begin{tabular}{|c|c|}
\hline \multicolumn{2}{|r|}{ PROJETO POLÍTICO PEDAGÓGICO } \\
\hline \multicolumn{2}{|r|}{ Concepção/fundamentos de ensino/aprendizagem } \\
\hline $\begin{array}{c}\text { PPP } \\
\text { Escola A }\end{array}$ & $\begin{array}{l}\text { - Tem como concepção a pedagogia em que o aluno é o centro das atividades } \\
\text { escolares, como ser ativo e curioso, com destaque para o princípio da } \\
\text { aprendizagem por descoberta, partindo do interesse pela experiência de cada } \\
\text { educando. }\end{array}$ \\
\hline $\begin{array}{c}\text { PPP } \\
\text { Escola B }\end{array}$ & $\begin{array}{l}\text { - Desenvolver o intelectual, moral e o cognitivo dos alunos, procurando um } \\
\text { desenvolvimento integral, para que possam participar de um futuro de evolução } \\
\text { tecnológica acelerada. }\end{array}$ \\
\hline \multicolumn{2}{|r|}{ Expectativas de aprendizagem em Geografia } \\
\hline $\begin{array}{c}\text { PPP } \\
\text { Escola A }\end{array}$ & $\begin{array}{l}\text { - Conhecer a organização do espaço geográfico e o funcionamento da natureza } \\
\text { em suas múltiplas relações, de modo a compreender o papel das sociedades em } \\
\text { sua construção e na produção do território, da paisagem e do lugar; } \\
\text { - Identificar e avaliar as ações dos homens em sociedade e suas consequências } \\
\text { em diferentes espaços e tempos, de modo a construir referenciais que } \\
\text { possibilitem uma participação propositiva e reativa nas questões } \\
\text { socioambientais locais; } \\
\text { - Compreender a espacialidade e temporalidade dos fenômenos geográficos } \\
\text { estudados em suas dinâmicas e interações; } \\
\text { - Compreender que as melhorias nas condições de vida, os direitos políticos, os } \\
\text { avanços técnicos e tecnológicos e as transformações socioculturais são } \\
\text { conquistas decorrentes de conflitos e acordos, que ainda não são usufruídas por } \\
\text { todos os seres humanos e, dentro de suas possibilidades, empenhar-se em } \\
\text { democratizá-las; } \\
\text { - Conhecer e saber utilizar procedimentos de pesquisa da Geografia para } \\
\text { compreender o espaço, a paisagem, o território e o lugar, seus processos de } \\
\text { construção, identificando suas relações, problemas e contradições; } \\
\text { - Fazer leituras de imagens, de dados e de documentos de diferentes fontes de } \\
\text { informação, de modo a interpretar, analisar e relacionar informações sobre o } \\
\text { espaço geográfico e as diferentes paisagens; } \\
\text { - Saber utilizar a linguagem cartográfica para obter informações e representar a } \\
\text { espacialidade dos fenômenos geográficos; } \\
\text { Valorizar o patrimônio sociocultural e respeitar a sociodiversidade, } \\
\text { reconhecendo-a como um direito dos povos e indivíduos e um elemento de } \\
\text { fortalecimento da democracia. } \\
\text { Conhecer a organização do espaço geográfico e o funcionamento da natureza }\end{array}$ \\
\hline & - Conhecer a organização do espaço geográfico e o funcionamento da natureza \\
\hline
\end{tabular}




\begin{tabular}{|c|c|}
\hline $\begin{array}{c}\text { PPP } \\
\text { Escola B }\end{array}$ & $\begin{array}{l}\text { em suas múltiplas relações, de modo a compreender o papel das sociedades em } \\
\text { sua construção e na produção do território, da paisagem e do lugar; } \\
\text { - Identificar e avaliar as ações dos homens em sociedade e suas consequências } \\
\text { em diferentes espaços e tempos, de modo a construir referenciais que } \\
\text { possibilitem uma participação propositiva e reativa nas questões } \\
\text { socioambientais locais; } \\
\text { - Compreender a espacialidade e temporalidade dos fenômenos geográficos } \\
\text { estudados em suas dinâmicas e interações; } \\
\text { - Compreender que as melhorias nas condições de vida, os direitos políticos, os } \\
\text { avanços técnicos e tecnológicos e as transformações socioculturais são } \\
\text { conquistas decorrentes de conflitos e acordos, que ainda não são usufruídas por } \\
\text { todos os seres humanos e, dentro de suas possibilidades, empenhar-se em } \\
\text { democratizá-las; } \\
\text { - Conhecer e saber utilizar procedimentos de pesquisa da Geografia para } \\
\text { compreender o espaço, a paisagem, o território e o lugar, seus processos de } \\
\text { construção, identificando suas relações, problemas e contradições; } \\
\text { Fazer leituras de imagens, de dados e de documentos de diferentes fontes de } \\
\text { informação, de modo a interpretar, analisar e relacionar informações sobre o } \\
\text { espaço geográfico e as diferentes paisagens; } \\
\text { - Saber utilizar a linguagem cartográfica para obter informações e representar a } \\
\text { espacialidade dos fenômenos geográficos; } \\
\text { Valorizar o patrimônio sociocultural e respeitar a sociodiversidade, } \\
\text { reconhecendo-a como um direito dos povos e indivíduos e um elemento de } \\
\text { fortalecimento da democracia. }\end{array}$ \\
\hline \multicolumn{2}{|r|}{ Projetos desenvolvidos que consideram o Lugar/Formosa } \\
\hline $\begin{array}{c}\text { PPP } \\
\text { Escola A }\end{array}$ & $\begin{array}{ll}\text { - } & \text { Carnaval; } \\
\text { - } & \text { Indo à cidade de Goiás. }\end{array}$ \\
\hline $\begin{array}{c}\text { PPP } \\
\text { Escola B }\end{array}$ & $\begin{array}{l}\text { - } \quad \text { Projeto momento cívico; } \\
\text { - Educação para a vida e valorização da leitura em todas as idades; } \\
\text { - Projeto Feira Literária. }\end{array}$ \\
\hline
\end{tabular}

Organização: Carvalho Sobrinho, 2016.

A escola A tem sua concepção pedagógica centrada no aluno, considerando-o como sujeito ativo e curioso, com destaque para o princípio da aprendizagem por descoberta. Considera-se um aspecto positivo quando o documento relata que a aprendizagem por descoberta parta do interesse pela experiência de cada educando. Assim, pode ser que este método valorize as experiências vividas dos educandos, qual seja o lugar. Mas, infelizmente, o documento não deixa claro essa perspectiva.

No que se refere às expectativas de aprendizagem em Geografia, compreende-se que, de modo geral, abrangem habilidades e competências importantes para a utilização na vida prática dos alunos. Em determinados momentos, percebemos o lugar sendo considerado, mas 
de forma genérica, sem destaque para a valorização do vivido. Porém, constatou-se que a expectativa de aprendizagem foi retirada ipsis literi dos Parâmetros Curriculares Nacionais. Esse ato de copiar essas expectativas dos PCNs, terceiro e quarto ciclos, evidencia que não foram elaboradas pelo corpo docente de ambas as escolas, o que dificulta a consideração do contexto vivido pelos sujeitos do espaço escolar. As expectativas devem ser construídas tendo como referência a comunidade escolar e os ritmos de aprendizagem dos alunos em contextos específicos. Os PCNs são norteadores das práticas pedagógicas em âmbito nacional, e devem ser ressignificados para considerar as diferenças regionais e locais, além, é claro, do contexto vivido pelos sujeitos (CARVALHO SOBRINHO; SUESS, 2014), e não um documento a ser copiado sem as devidas adaptações e reflexões que considerem a realidade da comunidade escolar.

Os projetos que são desenvolvidos na Escola A manifestam pouca utilização do Lugar/Formosa para a construção da aprendizagem. Além disso, não foi detectado nenhum projeto que envolva de forma direta a disciplina de Geografia. Entretanto, verificam-se dois em que se infere a utilização do lugar, mas se apresentam de forma tímida e bastante superficial, porque não fica claro em sua proposição, que a aprendizagem ocorra por e a partir da realidade vivida pelos sujeitos. Deste modo, negligencia o Lugar/Formosa para potencializar a construção de conhecimentos nas disciplinas em geral e na Geografia em particular.

Foi possível aferir, por meio da análise do PPP da Escola B, que sua visão em relação à concepção/fundamentos de ensino/aprendizagem está ligada à construção de um espaço inclusivo e democrático para todos. O texto expõe que o aluno é a referência da escola e que, enquanto uma instituição social, deve possibilitar o desenvolvimento integral dos alunos sob três perspectivas: intelectual, moral e cognitiva. Menciona que esse desenvolvimento integral possibilitará que os alunos possam participar de um futuro tecnológico, tendo em vista a sua formação. Considerou-se que o documento analisado é construído por meio de uma concepção mais democrática e dialógica. Nesse sentido, sua missão está atrelada a garantir a qualidade de ensino para todos e o conhecimento ali construído deve ser reflexivo, criativo, dinâmico, cultural e solidário, tendo como foco a formação de seres humanos conscientes, críticos e participativos na sociedade. Tais concepções se mantêm em um nível muito generalizante e não considera os sujeitos específicos. 
Por mais que a Proposta Político Pedagógica da Escola B apresente os projetos que são desenvolvidos, nota-se que não se preocupam em destacar o lugar vivido pelos alunos ou que a construção da aprendizagem, proposta na elaboração de cada projeto, efetive-se por e a partir da realidade vivida sujeitos. Assim, desconsideram o Lugar/Formosa para potencializar a construção de conhecimentos nas disciplinas, em geral, e na Geografia, em particular. Os projetos em que inferimos questões relativas ao lugar se apresentam de forma bastante superficial, pois não explicitam o Lugar/Formosa de maneira clara e muito menos que os conhecimentos a serem desenvolvidos por esses projetos se construam por intermédio da categoria lugar.

Diante dessas considerações, emergem-se alguns questionamentos: é possível construir conhecimentos significativos sem considerar o lugar em que os alunos vivem? Há possibilidades de construir um ensino que seja crítico, reflexivo, humanizado, cultural, dinâmico e solidário no qual esteja ausente o lugar? Evidentemente, que não. Mesmo que os PPPs de ambas as escolas, em determinados momentos, expressem questões progressistas, não estabelecem uma ligação com o lugar vivido pelo aluno de forma clara, elemento fundamental a ser considerado. Reiteramos que é por meio do cotidiano, que as construções dos conceitos se efetivam e que é preciso destacá-lo como elemento importante nas propostas político pedagógicas das escolas.

Ademais, consideramos que o PPP é um documento importante, por nortear as questões pedagógicas da escola. Ele permite que seja considerado o contexto dos alunos em sua amplitude na construção dos conhecimentos, ou seja, que o lugar, neste caso o Lugar/Formosa, seja considerado na construção dos conhecimentos geográficos. Contudo, nas considerações apresentadas naqueles documentos, percebeu-se que, na Geografia em particular, pouco consideraram o lugar como uma categoria mediadora da aprendizagem.

\subsubsection{Plano de Ensino de Geografia}

Neste momento apresentaremos o quadro com resultados e, posterior, análise dos Planos de Ensino dos professores de Geografia das escolas pesquisadas, para, desse modo, perceber a proposta pedagógica e metodológica utilizada na prática docente. 
Quadro 5 - Plano de Ensino - relação entre conteúdo e utilização do lugar

\begin{tabular}{|c|c|c|c|}
\hline PE & Ano & Conteúdos & Lugar \\
\hline $\begin{array}{c}\text { Escola } \\
\text { A }\end{array}$ & $9^{\circ}$ & Nenhum conteúdo foi detectado & $\begin{array}{c}\text { Nenhuma relação no que se refere } \\
\text { a essa categoria }\end{array}$ \\
\hline $\begin{array}{c}\text { Escola } \\
\text { B }\end{array}$ & $9^{\circ}$ & Nenhum conteúdo foi detectado & $\begin{array}{c}\text { Nenhuma relação no que se refere } \\
\text { a essa categoria }\end{array}$ \\
\hline
\end{tabular}

Organização: Carvalho Sobrinho, 2016.

Em relação aos planos de ensino, não obtivemos resultados, pelo fato de não terem sido elaborados. Assim, não foi possível identificar e analisar a relação dos conteúdos ministrados com a utilização do Lugar/Formosa no referido documento. Diante dessa situação, indagações pertinentes: qual o motivo da inexistência desse documento? Como é efetuado o planejamento para suas aulas? Onde o professor estabelece procedimentos para viabilizar a mediação pedagógica? Como são selecionados os conteúdos mais relevantes ao trabalho pedagógico no contexto em que as escolas estão inseridas? Será que o livro didático é o principal (talvez único) norteador dos conteúdos ministrados? É prejudicial para o contexto escolar não ter PE?

Considera-se que a ausência desse documento é prejudicial ao processo de ensino/aprendizagem em Geografia. Nesse sentido, é importante ressaltar, que os planos de ensino referem-se às ações de planejamento do professor em relação ao papel que desempenha na formação dos alunos. É por meio dele que o professor seleciona conteúdos e estratégias didático-pedagógicas, para construir conhecimentos com seus alunos, pois o ato de mediar exige preparação prévia. Além disso, possibilitam ao professor a manifestação de sua autonomia na seleção dos conteúdos mais significativos para a vida prática e para a formação da cidadania de seus alunos. Em relação ao presente caso, o PE poderia ter considerado o contexto vivido pelos alunos e sua relação com a construção da aprendizagem em Geografia em seus diversos conteúdos e linguagens. Como os professores não elaboraram seus PE, não temos como afirmar que planejam suas aulas e, nesse contexto, inserem os elementos postos pelo lugar, como via de mediação pedagógica. 
Pode-se afirmar, com base nas entrevistas (como será observado adiante), que são os conteúdos elencados no livro didático que conduzem a ação pedagógica dos professores. Por esse motivo, buscou-se identificar, nos livros didáticos, concepções que estão diretamente relacionados à presente pesquisa e ao processo de construção de conhecimentos geográficos. Não podemos desconsiderar o LD nesta análise, pelo fato de ser o recurso pedagógico mais utilizado na construção de conhecimentos na escola básica brasileira.

\subsubsection{O livro didático utilizado}

Nesse tópico, serão seguidos os critérios abaixo relacionados:

1. Apresentação geral do livro a ser analisado (capa, páginas, autor/autores, editora, ano de edição);

2. Análises das ilustrações, imagens, representações cartográficas, gráficos, quadros e tabelas;

3. Fidedignidade de informações e ausência ou presença de preconceitos;

4. Identificação de estímulo à observação, investigação, análise, síntese, criatividade e interpretação, entre outros, que se relaciona com o lugar;

5. Análise das atividades, no sentido de identificação das possibilidades de desenvolvimento de competências e habilidades por meio do lugar;

6. Tratamento da categoria lugar ao longo do livro.

O livro (Figura 6) do $9^{\circ}$ ano do Ensino Fundamental, de autoria de José William Vesentini e Vânia Vlach, faz parte do Projeto Teláris, da Editora Ática, que foi uma das coleções de livros adotados pela rede municipal de ensino do município de Formosa - Goiás, no triênio 2014 - 2016. 
Figura 7- Capa do livro Geografia do $9^{\circ}$ ano do Ensino Fundamental.

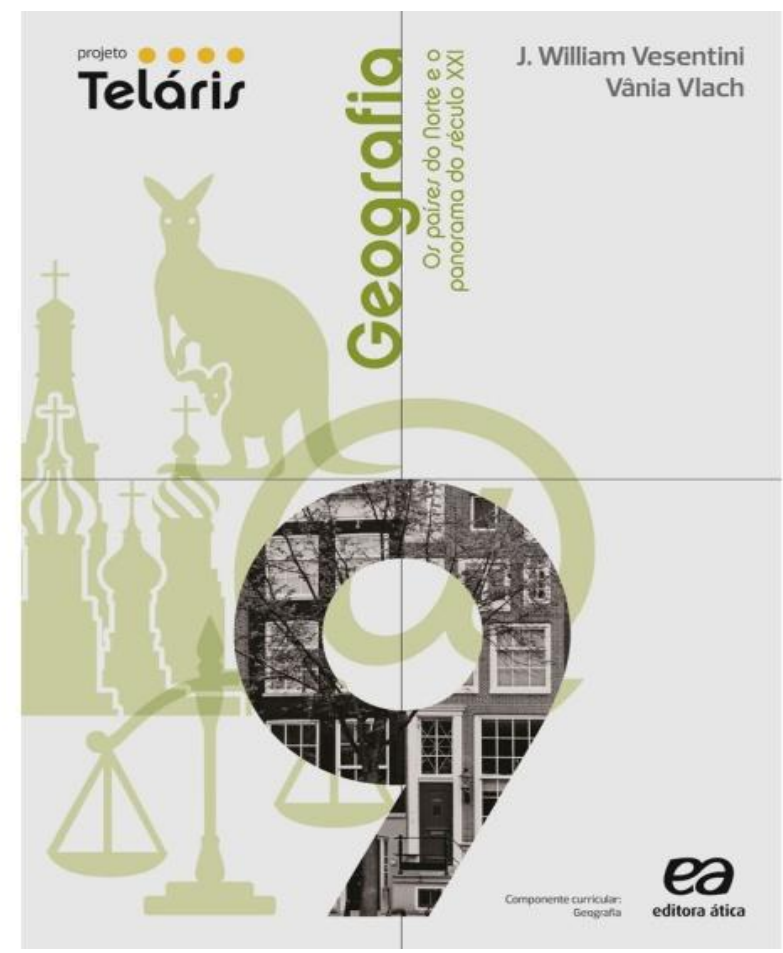

Fonte: Brasil, MEC. PNLD, 2014.

O primeiro autor do Livro é Doutor e Livre-Docente em Geografia pela Universidade de São Paulo (USP), professor e pesquisador do departamento de Geografia da USP, especialista em Geografia política/Geopolítica e ensino de Geografia, foi também professor do Ensino Fundamental e Médio da rede particular e oficial de ensino de São Paulo. Já a segunda autora, Doutora em Geopolítica pela Université de Paris, Mestra em Geografia Humana pela USP e professora do Programa de Pós-Graduação em Geografia da Universidade Federal de Uberlândia (UFU), além de ter sido professora da rede básica de ensino das redes oficial e particular de ensino do estado de São Paulo.

O livro didático, no que tange as questões mercadológicas, apresenta capa resistente e investigativa e possui símbolos geográficos, tais como, duas linhas (Equador e Greenwich), além dos símbolos que representam os conteúdos abordados. Em seu interior, encontram-se imagens, gráficos, tabelas, mapas, charges entre outros recursos de cores diferenciadas e com papel de boa qualidade, aspectos que se tornam importantes para chamar a atenção do aluno para a sua relação de aprendizagem com este instrumento. Para o caso dos termos mais complexos e que dificultem o entendimento dos alunos, apresenta um glossário no decorrer do livro, tendo como objetivo a compreensão dos conceitos ali apresentados. Sua encadernação é tipo brochura. 
A capa do livro se apresenta nas cores verde e branco, possuindo 344 páginas dedicadas ao processo de aprendizagem do aluno. Há fonte legível e com espaçamentos 1,5 $\mathrm{cm}$, o que possibilita uma boa visualização para a leitura.

$\mathrm{Na}$ apresentação os autores argumentam que existem livros cometas e livros estrelas. Os primeiros passam, porém os segundos permanecem. Nesse sentido, este livro estrela, segundo os autores, ajudará os alunos a ler e transformar o mundo em que vivem e torná-los cada vez mais capazes de exercer os direitos e deveres de cidadão.

Realizamos a análise geral de cada unidade, em que fizemos um pequeno resumo (quadro 6) do que se objetiva pedagogicamente em cada capítulo, com o intuito de destacar os conteúdos que integram o livro didático e perceber se estão de acordo com os documentos oficiais do ensino de Geografia para o respectivo ano. O livro é constituído por quatro unidades, sendo divididas em capítulos, sendo estes:

Quadro 6 - Organização dos conteúdos do Livro Didático do $9^{\circ}$ ano

\begin{tabular}{|c|c|}
\hline \multicolumn{2}{|r|}{1 Europa e CEI } \\
\hline Cap1. & $\begin{array}{l}\text { Leva o aluno a entender a Europa em conjunto: seus aspectos físicos e } \\
\text { humanos e os países que a compõem. }\end{array}$ \\
\hline Cap2. & $\begin{array}{l}\text { Objetiva estudar as diversidades regionais da Europa, com suas áreas mais } \\
\text { desenvolvidas e outras nem tanto. }\end{array}$ \\
\hline Cap3. & $\begin{array}{l}\text { Tem o intuito de estudar o que é a comunidade de Estados Independentes } \\
\text { (CEI) e quais são os países que compõem. }\end{array}$ \\
\hline Cap4. & $\begin{array}{l}\text { Trata da regionalização da CEI e a situação de vários países-membros dessa } \\
\text { comunidade. }\end{array}$ \\
\hline \multicolumn{2}{|r|}{2 América Anglo-Saxônica, Japão e Oceania } \\
\hline Cap5. & $\begin{array}{l}\text { Apresenta características dos dois países anglo-saxões da América do Norte: } \\
\text { Estados Unidos e Canadá. }\end{array}$ \\
\hline Cap6. & Trata das características socioeconômicas do Japão \\
\hline Cap7. & $\begin{array}{l}\text { Expõe os dois únicos países do chamado norte industrializado que se situam } \\
\text { ao sul da linha do equador. }\end{array}$ \\
\hline \multicolumn{2}{|r|}{3 Desigualdades internacionais } \\
\hline Cap8. & $\begin{array}{l}\text { Apresenta o conceito de IDH e o contexto de sua criação pelo Programa das } \\
\text { Nações Unidas. }\end{array}$ \\
\hline Cap9. & Estuda o porquê das desigualdades internacionais, isto é, entre os países e \\
\hline
\end{tabular}




\begin{tabular}{|l|l|}
\hline & entre as nações. \\
\hline Cap10. & $\begin{array}{l}\text { Apresenta a chamada economia moderna e expõe que a mesma não é igual em } \\
\text { todas as partes do mundo. }\end{array}$ \\
\hline Cap11. & $\begin{array}{l}\text { Evidenciam a questão da pobreza, fome e exclusão social, fenômenos que } \\
\text { estão interligados e que interferem na qualidade de vida dos seres humanos. }\end{array}$ \\
\hline Cap12. & $\begin{array}{l}\text { M Globalização, nova ordem e o cenário do século XXI } \\
\text { mudanças até o período atual. }\end{array}$ \\
\hline Cap13. & $\begin{array}{l}\text { Tem o intuito de estudar a chamada nova ordem mundial, que na verdade é } \\
\text { uma realidade dinâmica em construção. }\end{array}$ \\
\hline Cap14. & $\begin{array}{l}\text { Objetiva estudar as principais organizações internacionais que atuam no } \\
\text { mundo de hoje: ONU, Grupo dos Sete, Grupo dos Vinte, OMC, Unasul e } \\
\text { várias outras. }\end{array}$ \\
\hline Cap15. & $\begin{array}{l}\text { Apresenta os problemas demográficos mundiais: o envelhecimento da } \\
\text { população, aumento da obesidade e os problemas de racismo e intolerância. }\end{array}$ \\
\hline Cap16. & \begin{tabular}{l} 
Demonstra a importância da questão ambiental para o futuro da humanidade. \\
\hline
\end{tabular}
\end{tabular}

Organização: Carvalho Sobrinho, 2016.

Em relação às questões didáticas, o livro apresenta exemplos que fazem referência a seus próprios textos complementares, bem como as suas imagens, gráficos e tabelas. Seu conteúdo atende ao disposto nos PCNs (BRASIL, 2001). Entretanto, o livro foi organizado sem a preocupação de relacionar os conteúdos das demais unidades, tornando-os fechados em si mesmos, sem uma continuidade temática. Desse modo, deixa de fornecer uma sequência sistemática ao aluno, no percurso de sua aprendizagem.

As imagens, fotos, gravura, tabelas e gráficos são referenciados e todas possuem fonte e data de publicação. As informações estão, de modo geral, atualizadas. Os desenhos, fotografias, gráficos, representações cartográficas são nítidas, sendo um relevante aspecto para boa visualização do que se queira transmitir e relacionar. Elas instigam a curiosidade e se relacionam ao texto, porém não se detectou estímulo para pensar, por meio da categoria lugar, a relação dos conteúdos com o vivido pelos alunos. Consideramos que os conteúdos expressos no LD estão retratando, na maioria das vezes, outros países e continentes ${ }^{10}$, realidades

\footnotetext{
${ }^{10}$ Os conteúdos trabalhados estão sintetizados no quadro 6 , onde expõe o que se objetiva pedagogicamente cada capítulo.
} 
diferentes das vivenciadas pelo estudante, mas não se estabeleceu condições de significação destes por meio da categoria lugar.

Não foram detectados erros e as informações se apresentam corretamente, bem como o livro é ausente de preconceitos. As atividades propostas nas várias unidades não valorizam o lugar, pois foram identificadas poucas nas quais se conduz o aluno a pensar a relação dos conteúdos com o seu espaço vivido.

Vale lembrar que, de forma geral, o livro não evidencia qualquer tipo de preocupação com a categoria lugar, nem tampouco suas possibilidades de uso orientadas à aprendizagem do aluno. Todavia, deve-se ressaltar que o professor pode redimensionar e relacionar os conteúdos, tal como aplicá-los ao lugar, considerando-o elemento de mediação pedagógica orientado à sua significação, o que permitirá uma compreensão mais efetiva dos fenômenos geográficos por parte do aluno.

Tal consideração reafirma a importância do lugar ao processo de aprendizagem dos alunos em Geografia. Ao se considerar essa premissa, pode-se efetuar considerações acerca do livro didático de Geografia analisado: esse instrumento deve promover a inserção do aluno no processo de aprendizagem, para que se (re)conheça como sujeito atuante no seu mundo vivido, com implicações concretas em seu mundo não vivido e aguçar a curiosidade do aluno, ao criar as condições para que seja compreendida a ideia de que o espaço é uma construção social, onde ele se insere.

A esse respeito cabe mencionar que um processo de ensino-aprendizagem exitoso não deve se restringir apenas ao livro didático, visto que não há como transferir a responsabilidade dos conhecimentos para esse instrumento, mesmo que seja o mais utilizado pelo professorado brasileiro.

Assim, a análise realizada do LD utilizado pelos professores e alunos evidencia que a abordagem do lugar para a construção dos conhecimentos geográficos aparece de forma tímida o que, consequentemente, prejudicará a construção da aprendizagem do aluno de forma significativa, tendo em vista que é, segundo os próprios docentes, o LD que norteia as práticas pedagógicas em ambas as escolas pesquisadas.

O livro analisado nessa pesquisa compõe o Plano Nacional do Livro Didático (PNLD) 2014, o qual se encerra ao término deste ano. Após isto, outro triênio do programa, o PNLD 2017-2019, entrará em vigor e novamente milhões de livros serão distribuídos em todo o país. Como forma de vislumbrar uma formação e a valorização do espaço vivido pelo aluno e de 
sua formação enquanto sujeito e cidadão, novas pesquisas devem ser realizadas para verificar se o potencial de uso da categoria em pauta continua relegado a uma posição inferior, de um lado, e como, efetivamente, conduzir os envolvidos na relação ensino/aprendizagem à construção de conhecimento por meio do lugar, de outro.

Após as considerações no que se refere à pesquisa documental, passamos a analisar as entrevistas que foram realizadas com os professores. Destarte, destacamos que o papel exercido pelo professor é essencial na compreensão dos processos de ensinar/aprender Geografia, devido ser, por meio dele, que a mudança de mentalidade no ensino da Geografia se concretizará.

\subsubsection{Os professores e o Lugar/Formosa no processo de ensinar/aprender Geografia: análise das entrevistas}

Ensinar/aprender Geografia é o objetivo da mediação conduzida pelos professores. Todavia, muitos são os obstáculos encontrados para que se promova de fato um ensino que seja significativo para a vida prática dos alunos, e para a formação de cidadãos que sejam reflexivos e críticos perante as novas dinâmicas que se apresentam no mundo contemporâneo.

Neste momento iremos apresentar os resultados e análises das entrevistas com os docentes utilizando as reflexões teóricas realizadas anteriormente. Consideramos que, entre os sujeitos entrevistados, há semelhanças e diferenças em suas práticas pedagógicas em Geografia, apresentadas nos quadros que se seguem.

\subsubsection{Sistematização e análise dos quadros sínteses das entrevistas}

Os quadros que se seguem evidenciam pontos relevantes das entrevistas com os professores por grupo de perguntas. 
Quadro 7 - Síntese das respostas dos docentes - Primeiro encontro

\begin{tabular}{|c|c|}
\hline \multicolumn{2}{|r|}{ Por que razão você escolheu o curso de Geografia } \\
\hline Professor A & $\begin{array}{l}\text { Optei pelo curso de Geografia por me identificar muito com essa disciplina desde o } \\
\text { Ensino Fundamental. Além disso, tive professores que me inspiraram. Quando fui } \\
\text { para o Ensino Médio, lembro que, na época, em Formosa, Geografia era o curso } \\
\text { mais concorrido da UEG e Formosa tinha poucas opções. Lembro que passei na } \\
\text { terceira tentativa. Tive muita dificuldade, mas, a escolha do curso foi mais uma } \\
\text { questão de identificação, sempre gostei dessa disciplina e, também, por influência de } \\
\text { alguns professores, que ficaram marcadas na minha mente. }\end{array}$ \\
\hline Professor B & $\begin{array}{l}\text { Tive muita influência dos meus próprios professores de Geografia, pois tinham uma } \\
\text { maneira diferente de ministrar as aulas. Essa foi a maior razão de ter escolhido esse } \\
\text { curso. Outra questão que me influenciou foi a minha família, pelo fato de possuir } \\
\text { muitos educadores o que, de certo modo, fez e faz parte da minha vida. A Geografia } \\
\text { veio justamente para complementar tudo isso. Meu curso de Geografia ocorreu entre } \\
2005 \text { e 2009. Nesse período, eu acabei me identificando com a ciência geográfica, } \\
\text { aprimorando-a ainda mais minhas relações com os estudos. }\end{array}$ \\
\hline \multicolumn{2}{|r|}{ Quais eram as disciplinas preferidas na graduação } \\
\hline Professor A & $\begin{array}{l}\text { Tive disciplinas muito teóricas nos dois primeiros anos do curso e não gostava } \\
\text { muito. A partir do terceiro ano as disciplinas eram mais dinâmicas, ao retratar mais a } \\
\text { parte física: climatologia, geomorfologia, pedologia, geologia, entre outras. Essa } \\
\text { parte da Geografia física fez com que me encantasse porque chegamos a ter aula } \\
\text { prática, e por isso penso que o rendimento foi maior. Gosto mais da Geografia } \\
\text { física. }\end{array}$ \\
\hline Professor B & $\begin{array}{l}\text { Não gostava muito da parte teórica da Geografia, então a parte de teoria e método } \\
\text { eu não me identifiquei muito, eu tive professores excelentes em relação à disciplina, } \\
\text { mas eu sempre ficava mais ligado na questão da parte ambiental e física da } \\
\text { Geografia, então me interessava muito pela parte de geomorfologia, climatologia, } \\
\text { hidrogeografia entre outras. }\end{array}$ \\
\hline \multicolumn{2}{|r|}{ Experiência como docente de Geografia na cidade de Formosa - Goiás } \\
\hline Profess & $\begin{array}{l}\text { Minha experiência se inicia com um curso profissionalizante ofertado pela prefeitura } \\
\text { aos catadores da coleta seletiva para trabalhar com questões ambientais. Na } \\
\text { Educação Básica de Formosa, iniciei quando fui aprovada no concurso no ano de }\end{array}$ \\
\hline
\end{tabular}




\begin{tabular}{|c|c|}
\hline & $\begin{array}{l}\text { 2015. Penso que essa experiência, aqui na cidade, está sendo boa, acabo por } \\
\text { entender mais ainda a realidade de Formosa. O fato de trabalhar no município de } \\
\text { Formosa, observamos que têm alguns problemas, principalmente em relação à sala } \\
\text { de aula, pois a estrutura é muito precarizada, o que acaba sendo um complicador no } \\
\text { processo de aprendizagem, ou seja, nós sofremos muito por falta de recursos. }\end{array}$ \\
\hline Professor B & $\begin{array}{l}\text { Na cidade de Formosa, eu comecei como professor dando aula em escolas } \\
\text { particulares, mas também trabalhei no Município de Planaltina- GO em colégio } \\
\text { particular. Após passar no concurso do município em 2011, comecei a dar aulas em } \\
\text { âmbito municipal de forma efetiva. No início não tive uma experiência tão } \\
\text { agradável ao dar aula de Geografia. Uma coisa é você ter o conhecimento técnico } \\
\text { para dar aula, outra é você começar com o tempo a adquirir tudo isso. Obviamente a } \\
\text { prática e a teoria são coisas totalmente distintas, quando se trata de ensino e } \\
\text { aprendizagem. Assim, estou cada dia mais focado no meu trabalho e tentando ser } \\
\text { um professor diferente. }\end{array}$ \\
\hline \multicolumn{2}{|r|}{ Quais as principais dificuldades encontradas no exercício do seu magistério } \\
\hline Professor A & $\begin{array}{l}\text { Domínio e controle de sala; educação familiar; falta de investimento do governo nas } \\
\text { escolas; estrutura precária e a formação continuada que é ausente na secretaria. }\end{array}$ \\
\hline Professor B & $\begin{array}{l}\text { Condições inadequadas para exercer o magistério; falta de material didático; } \\
\text { avaliações que não condizem com a realidade; falta de espaço para dialogar sobre } \\
\text { formação continuada dos profissionais; muita verticalização da rede municipal e } \\
\text { estruturas precárias das escolas. }\end{array}$ \\
\hline
\end{tabular}

Organização: Carvalho Sobrinho, 2016.

As sistematizações iniciais das entrevistas indicaram similaridade nas respostas dos professores. Esse primeiro momento teve como objetivo conhecer os professores, suas experiências e seu processo de formação.

Os motivos que os levaram a optar pelo curso de Geografia se relacionam com a identificação com a disciplina na Educação Básica. Destacam a influência de outras pessoas, como professores e familiares.

Percebe-se que, no processo de formação inicial em Geografia, ambos preferiam as disciplinas da área física. $\mathrm{Na}$ fala deles, infere-se que acabaram por dicotomizar esta ciência, fragmentando-a em Geografia Física e Geografia Humana. Assim, ao serem argumentados sobre as disciplinas preferidas na graduação, destacaram que não gostavam das disciplinas 
mais teóricas (Humanas) e que preferiam as disciplinas mais práticas (Física), como por exemplo: geologia, geomorfologia, climatologia entre outras. Afirmam que a Geografia que trata de questões mais práticas é mais dinâmica, de tal maneira que o rendimento na graduação foi maior. Isso pode estar atrelado à concepção de Geografia obtida por meio do processo de formação inicial, que não considerou que a ciência geográfica se constitui como um sistema de objetos e ações que são indissociáveis (SANTOS, 2006), por conseguinte, não passíveis de fragmentação. Pela compreensão dicotomizada desses professores, deduz-se o predomínio de uma perspectiva tradicional em suas formações.

Essa dicotomia, observada nos relatos dos professores, ainda está presente nos cursos de Geografia e colabora para que o professor tenha uma formação fragmentada e a reproduza quando constrói os conhecimentos geográficos com os alunos. Essa fragmentação é manifestada na Geografia o que, infelizmente, faz com que o professor faça uma leitura enviesada da ciência geográfica, deixando de considerar e relacionar os elementos físicos e humanos, que, para a Geografia, são indissociáveis. A fragmentação perpassa a formação do geógrafo ao longo do curso, pela divisão entre o bacharelado e a licenciatura o que é alvo de críticas por existir esse viés.

Esta discussão se apresenta cada vez mais complexa no âmbito da ciência geográfica e, especificamente, na Geografia Escolar, pois influencia decisivamente na formação do professor. Desse modo, o processo de ensinar/aprender Geografia se insere nesse contexto de fragmentação na formação dos professores no Brasil, em Goiás e na cidade de Formosa - GO. A inferência feita a partir das respostas dos professores nos remete a um assunto preocupante, ou seja, se o professor é formado numa perspectiva fragmentada, provavelmente sua abordagem na sala de aula, tenderá a reproduzir isso. Em consequência, é igualmente improvável que consiga integrar os diversos conteúdos no contexto das discussões relativas ao ensino. Exceto quando, na reflexão dos resultados da sua prática, bem como, na formação continuada ele consiga superar as lacunas da formação inicial, por esta ter um peso muito grande na prática pedagógica de qualquer professor. Contudo não é uma variável determinante, pois a autonomia (busca própria) deste profissional também influencia no seu fazer pedagógico.

Em relação à experiência dos professores na cidade de Formosa, percebeu-se que já trabalharam em outras Secretarias de Educação o que, segundo eles, contribuiu para o amadurecimento pedagógico. O Professor A destaca que é uma experiência significativa trabalhar em Formosa, porque faz com que conheça a realidade da cidade, que por sinal, é 
bastante precária. O Professor B enfatizou que no início não teve uma experiência muito boa, visto as dificuldades estruturais das escolas, uma vez que, segundo ele, as estruturas são precárias e acaba por implicar na prática pedagógica.

Todavia, se analisamos as falas dos docentes - quadro 8 - percebemos que, em determinados momentos, destacam que utilizam diferentes instrumentos, tais como: mapas, datashow, jornais, globos, vídeos. Além disso, a pesquisa exploratória detectou que as escolas possuem uma estrutura física boa e recém reformada (Escola A), ou seja, há antagonismos nas falas dos professores, pois, quando analisamos sua prática pedagógica,percebemos que as instituições de ensino citadas possuem alguns instrumentos para mediar e auxiliar a construção dos conhecimentos geográficos.

Detectamos similaridades, também, nas respostas dos professores que apontam como principais problemas que influem na sua prática pedagógica: educação familiar; falta de investimento do governo nas escolas, falta de formação continuada, condições inadequadas para o exercício do magistério, entre outros. E, como se não bastasse, os professores ressaltam a verticalização dos processos pedagógicos, ou seja, muitas vezes as normas elaboradas não fazem parte de uma construção conjunta e dialogada.

Nesse sentido, os professores podem apontar motivos e obstáculos que interferem no seu fazer pedagógico, tendo em vista a busca por mudanças, mas não devem esquecer que tais problemas não podem ser utilizados como "muletas", para justificar a ineficácia do processo de ensino/aprendizagem em Geografia. A função primordial do ensino de Geografia, na Educação Básica, é garantir, mesmo diante de adversidades, um ensino de qualidade para que os alunos possam realizar suas práticas socioespaciais e, assim, reconhecerem a si como agentes que constroem o espaço geográfico, mediante os usos cotidianos de sua apropriação. É nesse sentido, que devemos considerar a questão da cidadania e sua presença como agente ativo na sociedade em que está inserido.

Quadro 8 - Síntese das respostas dos docentes - Segundo encontro

Que importância você atribui ao ensino de Geografia

\begin{tabular}{|l|l|}
\hline Professor A & $\begin{array}{l}\text { A Geografia é fundamental para o aluno, na verdade para o ser humano. Penso que } \\
\text { ela contribui para os alunos poderem se situar, saber onde vivem e a questão de } \\
\text { lugar, de território, de localidade, de espaço. Ao ensinar, devemos focar nisso, } \\
\text { formar um cidadão que tenha senso crítico, para, quando sair da escola, ou, por } \\
\text { exemplo, quando sair de uma aula de Geografia, que ele veja uma reportagem da } \\
\text { política brasileira, em que ele veja falando sobre os atentados lá na França, que eles }\end{array}$ \\
\hline
\end{tabular}




\begin{tabular}{|c|c|}
\hline & $\begin{array}{l}\text { consigam ver, visualizar, entender e saber falar e dar opinião sobre aquele tema. Às } \\
\text { vezes, até mesmo da cidade de Formosa, como falo na parte ambiental, que ele saiba } \\
\text { que a Mata da Bica é um dos pontos importantes da área de Formosa, bem como sua } \\
\text { mata nativa, da importância dos córregos na cidade, então isso é importante para que } \\
\text { seja despertado neles esse senso de saber criticar e preservar a natureza. Por que eu } \\
\text { tenho que preservar? Porque eu tenho que saber sobre a política? O que os } \\
\text { vereadores fazem, ou o que o prefeito faz? A Geografia tem essa função de } \\
\text { despertar neles a curiosidade, esse senso crítico, para que eles exerçam a cidadania } \\
\text { de forma completa e correta. }\end{array}$ \\
\hline Professor B & $\begin{array}{l}\text { Creio que a Geografia tem uma função social muito grande dentro do ensino, se } \\
\text { fossemos fazer um link com as outras áreas, diria que a Geografia tem uma } \\
\text { capacidade muito grande de analisar o espaço, tanto do ponto de vista social, } \\
\text { econômico e político, entender as relações que acontecem nele, entender o que são } \\
\text { essas inter-relações, assim penso que a importância da Geografia se resume em } \\
\text { permitir que o aluno analise o espaço do ponto de vista da criticidade de interferir e } \\
\text { possibilitar mudanças. }\end{array}$ \\
\hline \multicolumn{2}{|c|}{ Como você avalia a situação do ensino de Geografia em Formosa e no Brasil na atualidade } \\
\hline Professor A & $\begin{array}{l}\text { Acredito que a Geografia tem crescido bastante, entretanto não está sendo } \\
\text { valorizada a área do ensino, por isso a procura em ser professor sempre está } \\
\text { diminuindo. Estamos estagnados nesse sentido. Acredito ainda, que um dos pontos } \\
\text { principais é a questão da valorização do profissional da educação e a falta de } \\
\text { recursos pedagógicos. Não temos nem mapas para trabalhar. Em Formosa não há } \\
\text { um esforço da secretaria de educação para que sejam promovidos projetos } \\
\text { interdisciplinares. Acontece muito pouco, mas por iniciativa dos professores, } \\
\text { quando tem. }\end{array}$ \\
\hline Professor B & $\begin{array}{l}\text { Em nível de Brasil penso que o ensino de Geografia precisa avançar bastante, } \\
\text { sobretudo em relação a essas categorias de ensino específicas da Geografia, o } \\
\text { ambiente local em si, das próprias paisagens, o espaço em si, acho que os livros } \\
\text { didáticos sempre focam muito na parte descritiva e às vezes essas categorias ficam } \\
\text { em segundo plano, então acho que essa realidade que o aluno vivencia em nível de } \\
\text { Brasil, ela não é tão bem.Aqui não tem um vínculo social muito grande na prática do } \\
\text { ensino de Geografia, não se propõe discussões para que tornem os alunos cidadãos } \\
\text { para atuarem de fato na construção de uma sociedade melhor. }\end{array}$ \\
\hline \multicolumn{2}{|r|}{ Como você trabalha as aulas de Geografia: especificar } \\
\hline Professor A & $\begin{array}{l}\text { Faço do seguinte modo: sigo o livro didático e, geralmente, levo textos para poder } \\
\text { acrescentar coisas na aula. Imprimo textos e utilizo vídeos. Ainda mais com temas } \\
\text { do } 9^{\circ} \text { ano que abordam muito de localização: Europa, América, Estados Unidos, } \\
\text { Guerra fria, Globalização, entre outros. Então, são conteúdos que ao meu modo de } \\
\text { ver eles precisam visualizar, assim gosto de levar vídeo, gosto de trabalhar com } \\
\text { datashow, com mapas, globo. Sempre levo mapas para que eles possam pintar. Por } \\
\text { exemplo, quando vou dar aula sobre a Europa, continente europeu, levo o mapa para } \\
\text { eles pintarem, para eles poderem saber, para situarem onde está o continente } \\
\text { europeu, quais são os países, quais são as capitais desses países, para que eles } \\
\text { tenham uma ideia e, ao pegar um mapa, eles saberem. Então assim, por exemplo, } \\
\text { passei um vídeo sobre Guerra Fria para eles, eu pedi um relatório. Quando passo } \\
\text { algum filme e documentário, gosto que eles façam análise. Também fiz e faço } \\
\text { debate na sala de aula. Outro exemplo é o conteúdo de globalização que é tema que } \\
\text { trabalhamos no final do segundo bimestre, é um tema que gera geralmente muita } \\
\text { discussão, então eu gosto de fazer uma roda ou às vezes eu coloco perguntas para } \\
\text { eles responderem. E essas perguntas são elaboradas por meio do livro didático. Olha } \\
\text { geralmente quando eu passo vídeo, a gente faz... Na verdade antes de passar o vídeo }\end{array}$ \\
\hline
\end{tabular}




\begin{tabular}{|c|c|}
\hline & $\begin{array}{l}\text { geralmente já tem um conteúdo introdutório, para poder focar alguma coisa, por } \\
\text { exemplo, eu estava dando aula sobre o Oriente Médio, passando um vídeo sobre a } \\
\text { Al-Qaida, Osama Bin Laden, para eles poderem aprender uma realidade que não é } \\
\text { deles, que não fazem parte daqui, mas que têm que aprender. Então, geralmente tem } \\
\text { toda uma introdução, passo o vídeo para focar aquele tema, ou algo transversal } \\
\text { àquele tema. E geralmente discutimos em relação ao vídeo, faço uma análise, peço } \\
\text { para eles fazerem uma análise escrita do que eles entenderam. Além disso, têm as } \\
\text { atividades normais, exercícios do livro didático para poderem responder. } \\
\text { Geralmente é nessa mesma dinâmica que trabalho os conteúdos. }\end{array}$ \\
\hline Professor B & $\begin{array}{l}\text { Dentro do processo de ensino aprendizagem existem várias teorias para aplicar } \\
\text { dentro do ensino, especificamente, na minha prática, procuro sempre vivenciar a } \\
\text { realidade do aluno, entendendo primeiramente seu ambiente local, do lugar em si e } \\
\text { depois para entender outras dimensões. Porque eu entendo que, se conseguir trazer o } \\
\text { aluno primeiramente para seu ambiente conseguirei mostrar outras dimensões da } \\
\text { Geografia que são importantes, inclusive inter-relacionando conteúdos que têm } \\
\text { outras ligações em âmbito global e internacional. Penso que o ensino do } 9^{\circ} \text { ano, } \\
\text { especificamente, é um ensino voltado para aspectos globais pelas relações } \\
\text { econômicas que acontecem em âmbito mundial, assim não preciso mostrar para o } \\
\text { aluno quais são as características de cada país e as relações físicas que acontecem } \\
\text { ali, mas eu preciso mostrar para ele qual é o entendimento dessa realidade dentro do } \\
\text { seu espaço, qual é sua história, o seu contexto geográfico, então isso eu valorizo } \\
\text { muito. Essa minha prática de mostrar para o aluno essa realidade, interligando } \\
\text { conteúdos, acaba dando certo, sobretudo porque, a partir disso, que ele consegue ter } \\
\text { uma vivência melhor em relação ao que é debatido. Procuro passar muitos filmes, } \\
\text { documentários, entendendo que também é uma forma diferenciada da gente poder } \\
\text { fazer abordagens que talvez o aluno não vivencie, não entende. Tento não ser } \\
\text { tradicional, na maior parte das vezes, sobretudo por causa desses aspectos que eu } \\
\text { citei, mas, em determinados momentos, temos que usar o tradicional porque a } \\
\text { realidade não permite que você especifique tanto, ela tem outro foco que não é esse } \\
\text { que a gente tenta trabalhar. Utilizo vídeos, porque, dentro de um conteúdo de } \\
\text { Geografia física, preciso mostrar outras realidades, como formas de relevo e coisas } \\
\text { do tipo, e eu sei que o aluno não tem essa vivência dessas realidades, eu vou } \\
\text { ressignificar de alguma forma, eu não posso sair a campo, mas eu posso usar outro } \\
\text { recurso midiático para que ele possa entender essa relação. }\end{array}$ \\
\hline \multicolumn{2}{|r|}{ Quais os problemas que você identifica na sua prática pedagógica } \\
\hline Professor A & $\begin{array}{l}\text { Falta de pré-requisito dos alunos; apoio da família nas atividades; indisciplina; falta } \\
\text { de interesse; faltam instrumentos pedagógicos; salas superlotadas; influência } \\
\text { negativa das redes sociais; estrutura ruim; falta formação continuada. Esses são } \\
\text { alguns problemas que identifico na minha prática pedagógica. }\end{array}$ \\
\hline Professor & $\begin{array}{l}\text { Pré-requisito dos alunos; indisciplina; falta de instrumentos pedagógicos; salas } \\
\text { superlotadas; precárias estruturas das escolas; falta formação continuada; pouca } \\
\text { participação dos pais na escola. São problemas que influem a minha prática. }\end{array}$ \\
\hline
\end{tabular}

Organização: Carvalho Sobrinho, 2016.

No tocante à importância que os professores conferem ao ensino de Geografia, observou-se a consideração de que a disciplina colabora para a efetivação da discussão sobre cidadania, por meio do cotidiano dos aluno. Nesse sentido, os entrevistados apresentam a consciência de que o lugar, nesse contexto, é fundamental. Porém, consideramos que, mais 
que a consciência, o conhecimento da realidade vivida deve ocasionar o reconhecimento do lugar, posicionamento pessoal e coletivo, com suas devidas explicações de forma crítica e responsável e ainda, viabilizar, por meio de atividades no ensino dessa disciplina, a compreensão dos fenômenos geográficos ali localizados e sua relação com o mundo. Esse é um dos sentidos da construção da cidadania no ensino de Geografia, a partir do lugar (LEITE, 2012).

Os docentes advogam que, por meio da Geografia, os alunos podem ser sujeitos mais críticos para interferir e buscar soluções para os problemas da sociedade.

A Geografia acaba suscitando o aluno, despertando nele um lado mais crítico. No cotidiano, por exemplo, onde você mora? A sua cidade é de qual origem? De qual estado? Você faz parte de qual país? Então, tudo isso está envolvido, inserido no dia a dia, no cotidiano deles. Em relação ao meio ambiente, por exemplo, acaba por despertar o senso crítico. Assim, acaba que até mesmo a origem da vida dele está inserida na Geografia. Ela está inserida no cotidiano deles, e é muito importante nesses fatores, no senso crítico, no senso de localização, em relação ao meio ambiente, a educação ambiental. Além disso, nosso objetivo é formar um cidadão, que esteja preparado para sociedade (PROFESSOR A, 2016).

A importância do ensino em Geografia, além da análise espacial, seria permitir com que o aluno possa ver o espaço em que ele vive de maneira crítica, de maneira mais atuante, para que ele possa interferir ali e propor soluções (PROFESSOR B, 2016).

Embora reconheçam o valor do ensino de Geografia na formação dos alunos, notam-se obstáculos para que os objetivos dessa disciplina se concretizem. Evidenciam que o ensino é desvalorizado na escola básica em nível de Brasil e, no que se refere à Formosa - GO, a situação é ainda pior, pois relatam que não possuem recursos apropriados para ofertar um ensino de Geografia que seja significativo. Ambos entrevistados criticam as estruturas das escolas da cidade, como pode ser observado no quadro 8.

Falando da realidade, a situação do ensino de Geografia em Formosa - GO é bastante complicada, por causa das estruturas das escolas e das novas tendências do momento como, por exemplo, as organizações sociais e, além disso, eles só focam em matemática e português como se as outras disciplinas não fossem importantes para a prática da cidadania (PROFESSOR A, 2016). 
Ademais, um dos professores entrevistados crítica a desorganização existente na Secretaria de Educação, no sentido de permitir que docentes sem habilitação específica ministrem aulas de Geografia, segundo ele é a realidade vivenciada não só nessa disciplina, mas em várias outras.

Os professores esbarram em questões burocráticas do sistema, que a meu ver, é falta de organização. Sabemos que tem professor na área de Geografia, que tem professores específicos que podem assumir o magistério, mas eles assumem outras disciplinas para complementar sua carga, é a própria desorganização e que acaba por defasar o ensino da disciplina (PROFESSOR B, 2016).

Mesmo que os docentes reconheçam que o ensino de Geografia possa contribuir para a formação crítica dos alunos, percebe-se que há uma incongruência entre o que teorizam sobre os objetivos dessa disciplina e o que realmente é realizado na prática, pois relatam que, por causa de problemas latentes, citados no quadro 8, que não são resolvidos,o ensino em Formosa continuará bastante tradicional. Ou seja, eles têm a consciência que é difícil realizar uma práxis pedagógica, que seja condizente com a realidade dos alunos, sem amparo da rede de ensino e que, por esse motivo, permanecem nas práticas tradicionais, as quais, de certo modo, não são adequadas à formação da cidadania.

Podem-se assinalar causas e responsáveis para as dificuldades relatadas pelos professores, porém, mais importante que isso, é assumir que tais problemas existem e se constituem obstáculos à qualidade do ensino. É necessário, então, que se busquem alternativas condizentes e responsáveis contra esse sistema excludente e segregador, por meio de práticas viáveis ao exercício da cidadania.

Como pode ser observado no quadro 8, o Professor A expõe que segue o livro didático como o recurso central, mas que incrementa suas aulas com outros, tais como: textos, mapas, globo, documentários, vídeos, filmes. Segundo ele, os conteúdos do $9^{\circ}$ ano se apresentam de forma dinâmica, o que faz necessário a utilização de vários recursos na sua prática pedagógica. Evidencia, também, que suas aulas se apresentam de forma dialogada com os alunos. No entanto, mesmo cientes da dinamicidade dos conteúdos do $9^{\circ}$ ano, não os relacionam com os fenômenos geográficos que são manifestados na própria cidade dos alunos, ou seja, não consideram as vivências e experiências do aluno, logo, não contemplam a cidade como um lugar de materialização das relações sociais, conforme aponta Carlos (2004). 
Durante as entrevistas, observou-se que o livro didático é o recurso mais utilizado e que norteia a prática pedagógica dos professores. Ele é um instrumento importante na realidade escolar brasileira: "Utilizo também o livro didático como instrumento que norteia os conteúdos a serem trabalhados" (PROFESSOR B, 2016). Entretanto, se voltarmos à análise que foi realizada do livro didático utilizado pelos professores na parte documental, percebe-se que há muito o que avançar em relação à utilização da categoria lugar na construção dos conhecimentos geográficos. Os conteúdos são amplos, mas em escalas que não dialogam ou são distantes da vida cotidiana dos alunos, não permitem analogias, comparações e não oferecem muitas possibilidades de construção da aprendizagem por meio desta categoria.

O Professor B, quando argumentado sobre como trabalha os conteúdos de Geografia com os alunos, enfatiza que o processo de ensinar/aprender é complexo e pode ser mediado por várias teorias e práticas. Evidencia que as suas atividades estão relacionadas à finalidade de levar o aluno a compreender a sua realidade:

Procuro muitas vezes mostrar para o aluno como de fato está a sociedade, levo jornais e revistas, em determinadas aulas para poder debater. Então a minha prática em sala de aula está ligada ao que o aluno vivencia na sua realidade (PROFESSOR B, 2016).

Ao analisar a fala do professor, observa-se que, ao responder essa indagação sobre a sua experiência de ensino, muitas vezes, relata que é preciso levar o aluno a compreender os conteúdos por meio da sua realidade, ponto importante a ser evidenciado na sua perspectiva de docente. Mas percebemos uma ambiguidade em sua fala quando destaca:

Por de não ter apoio da secretaria, poucas vezes saímos a campo, quase sempre saídas muito esporádicas e às vezes locais, que teoricamente, do ponto de vista geográfico, o aluno já conhece, já estabelece relações. O ideal, dentro dessa prática, deveria ser a visão de outras realidades, o que, para o aluno, seria algo muito interessante, para despertar a capacidade de ressignificar aquilo que não viu ou que não observou (PROFESSOR B, 2016).

Esse argumento do professor B confirma que a categoria lugar não é vista como mediadora em sua prática pedagógica. Isso pode ser observado por meio de seu relato, sistematizado no quadro 9, no qual não se menciona o uso do Lugar/Formosa. Assim, infere- 
se que a abordagem dos conteúdos, por meio da realidade, só se apresenta no discurso, uma vez que não se observa na prática. Que prática é essa que compreende a realidade, mas que, ao mesmo tempo, não considera o lugar dos alunos na construção dos conhecimentos geográficos? É preciso entender que as saídas de campo e/ou referências aos locais possibilitariam a construção dos conhecimentos geográficos na sua relação local-global, a partir de uma realidade vivenciada pelos estudantes. Ou seja, a cidade dos alunos é um lugar de vida e experiências com os fenômenos geográficos, na medida em que a relação do sujeito com o seu espaço é de interação ativa e dialética, ao trazer o real e cotidiano a um patamar inicial de análise (CASTELLAR; VILHENA, 2010).

Assim sendo, atrelado ao debate que realizamos sobre a categoria lugar em Geografia, esta deve ser utilizada na perspectiva de significação aos conteúdos da disciplina, para viabilizar a internalização de conceitos que façam sentido na vida do aluno para que, através dela, o aluno possa pensar a espacialidade e estabelecer uma leitura do mundo (LEITE, 2012). Não desconsideramos a importância do conhecimento de outras realidades, mas o ideal seria mostrar a interligação das outras realidades com o vivido pelos alunos para que os conhecimentos tenham aplicação prática imediata e, consequentemente, contribuir para a cidadania crítica na construção desses conhecimentos.

Sobre as dificuldades encontradas pelos professores para realizar seu trabalho, foram relatadas causas internas e externas a sala de aula como: falta de pré-requisito dos alunos; apoio da família nas atividades; indisciplina; desinteresse no que é ensinado; faltam instrumentos pedagógicos; salas superlotadas; falta de formação continuada; pouca participação dos pais na escola, entre outros.

É um desafio conciliar a teoria e prática no ensino de Geografia no âmbito municipal, porque ficamos a mercê de um sistema que, infelizmente, não oferece condições para que se busque essa relação, não possuímos recursos adequados e as vezes vivemos em um patamar de reclamação (PROFESSOR B, 2016).

Consideramos importante que os professores percebam os motivos que, de certo modo, interfiram na oferta de um ensino de Geografia de qualidade e significativo, como também, das demais disciplinas, e busquem criticar a estrutura que se apresenta de forma precarizada, sem relação entre teoria e prática. 
Não nos interessa culpar o professor, mas ressaltar que existem possibilidades, mesmo na adversidade, para se construir um ensino, que leve os alunos e professores a se posicionarem contra o sistema de precarização e exclusão imposta à escola. Se os alunos possuem dificuldades, cabe ao docente buscar alternativas para supri-las, com práticas pedagógicas viáveis. Dessa maneira, no ensino de Geografia, consideramos que a categoria lugar dispõe do potencial de ser utilizado como um instrumento viável, por estar presente no cotidiano do coletivo escolar. Porém, sequer é considerado na prática desses professores.

Quadro 9 - Síntese das respostas dos docentes - Terceiro encontro

\begin{tabular}{|c|c|}
\hline \multicolumn{2}{|r|}{ Quais os conteúdos de Geografia do $9^{\circ}$ ano que você ministra } \\
\hline Professor A & $\begin{array}{l}\text { Os conteúdos são do livro didático - Europa: uma divisão de conjunto; Europa } \\
\text { diversidades regionais; CEI: aspectos gerais; CEI: aspectos regionais; Estados } \\
\text { Unidos e Canadá; Japão; Austrália e Nova Zelândia; Índice de Desenvolvimento } \\
\text { Humano; Origem das desigualdades sociais; Os três mundos: economia de mercado } \\
\text { e planificada; Pobreza, fome, e exclusão social; Divisão internacional do trabalho à } \\
\text { globalização; Nova ordem mundial, uma realidade em construção; As organizações } \\
\text { internacionais e o seu papel no mundo atual; A questão demográfica; A questão } \\
\text { ambiental na nova ordem mundial. }\end{array}$ \\
\hline Professor B & $\begin{array}{l}\text { O livro e os conteúdos do } 9^{\circ} \text { abordam a questão da geopolítica mundial - Os } \\
\text { conteúdos são os que constam no livro didático - Europa: uma divisão de conjunto; } \\
\text { Europa diversidades regionais; CEI: aspectos gerais; CEI: aspectos regionais; } \\
\text { Estados Unidos e Canadá; Japão; Austrália e Nova Zelândia; Índice de } \\
\text { Desenvolvimento Humano; Origem das desigualdades sociais; Os três mundos: } \\
\text { economia de mercado e planificada; Pobreza, fome, e exclusão social; Divisão } \\
\text { internacional do trabalho à globalização; Nova ordem mundial, uma realidade em } \\
\text { construção; As organizações internacionais e o seu papel no mundo atual; A questão } \\
\text { demográfica; A questão ambiental na nova ordem mundial. }\end{array}$ \\
\hline \multicolumn{2}{|r|}{ Como você trabalha esses conteúdos de Geografia: especificar } \\
\hline Professor A & $\begin{array}{l}\text { Quando comecei no } 9^{\circ} \text { ano, logo de início, fiz o que? Iniciei pela Europa, mostrando } \\
\text { a sua localização no mapa mundi. Levei o mapa para eles desenharem, porque eles } \\
\text { gostam muito dessa parte de desenho, de figuras. Fiz o seguinte: pedi para } \\
\text { desenharem o mapa mundi e identificar os países que compõem o continente } \\
\text { Europeu. A partir daí, eles pintaram, e conseguiram visualizar os países desse } \\
\text { continente. Depois entrei com o conteúdo do livro didático. Pedi para elencarem no } \\
\text { caderno os principais pontos que são abordados desses conteúdos em forma de } \\
\text { resumos e tópicos. Isso na parte inicial, claro. Após, fui falar sobre União Europeia, } \\
\text { trabalhei sua existência, o que é o bloco econômico da Europa elevei para eles um } \\
\text { vídeo sobre a União Europeia, sobre quais os países que faziam parte, e mostrava } \\
\text { também a importância mundial desse bloco econômico. Tudo isso era apresentado } \\
\text { no vídeo. Depois do vídeo, eu expliquei os pontos principais e pedi para que } \\
\text { fizessem uma análise do vídeo no caderno (em especial, os pontos que chamassem } \\
\text { mais a atenção). Ao término, fizemos uma discussão na sala sobre o conteúdo do } \\
\text { vídeo sobre a União Europeia. } \\
\text { Depois vimos o conteúdo sobre os Estados Unidos e Canadá. Assim, quando }\end{array}$ \\
\hline
\end{tabular}




\begin{tabular}{|c|c|}
\hline & 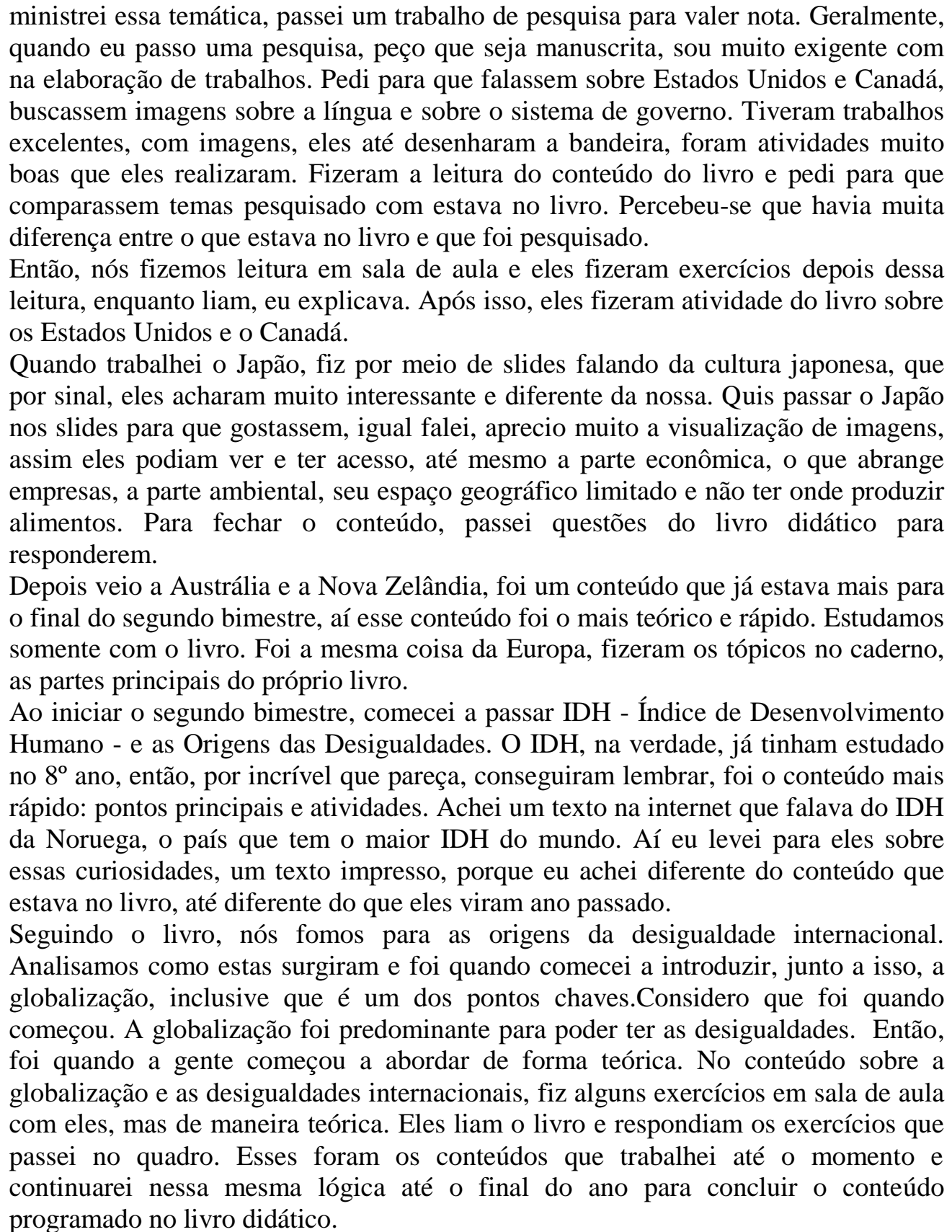 \\
\hline Professor B & $\begin{array}{l}\text { Então, na abordagem dos conteúdos que eu vou ministrar, sempre procuro usar o } \\
\text { datashow e vídeos. Não fico somente no livro didático, mas abordo os conteúdos } \\
\text { usando os recursos que tenho a meu dispor, e que, muitas das vezes, esbarram } \\
\text { também na questão de indisponibilidade, pela questão de ter pouco material e pouca } \\
\text { infraestrutura, visto todo mundo querer usar. De forma lúdica, a gente procura fazer } \\
\text { debates em relação a esses temas, por exemplo, na última vez quando trabalhamos o } \\
\text { conteúdo do primeiro bimestre. No segundo bimestre, trabalhando agora a Europa, } \\
\text { discutimos, baseado em reportagens, as visões que se tem da permanência do Reino } \\
\text { Unido, bem como sua exclusão, porque que aceitou e não aceitou. Então, ao } \\
\text { compreender essas relações que acontecem no mundo dentro dos conteúdos, isto é } \\
\text { ressignificado da melhor forma possível, os alunos passam a absorver da melhor } \\
\text { forma possível a temática e fica muito mais interessante também a aula, muito mais } \\
\text { dialógica do que somente o professor falando. Nas minhas aulas, a participação é } \\
\text { fundamental, acho que a compreensão dessa participação também é fundamental e } \\
\text { devemos valorizar isso dentro dos conteúdos. Na minha abordagem, eu procuro }\end{array}$ \\
\hline
\end{tabular}




\begin{tabular}{|c|c|}
\hline &  \\
\hline \multicolumn{2}{|c|}{ Quais os problemas você identifica na sua prática pedagógica ao trabalhar esses conteúdos } \\
\hline Professor A & $\begin{array}{l}\text { Os problemas que identifico são os que falei anteriormente como a falta de recursos } \\
\text { didáticos para trabalhar esses conteúdos e torná-los mais atraentes. Falta de pré- } \\
\text { requisitos dos alunos e um comportamento indisciplinado em sala de aula acaba } \\
\text { influenciando muito. }\end{array}$ \\
\hline
\end{tabular}




\begin{tabular}{|l|l|}
\hline \multirow{3}{*}{ Professor B } & $\begin{array}{l}\text { Faltam pré-requisitos dos alunos para trabalhar os novos conteúdos. A questão } \\
\text { burocrática, infelizmente, prejudica muito o meu trabalho. Não tem apoio nenhum } \\
\text { da Secretaria Municipal de Educação para que o professor de Geografia faça uma } \\
\text { prática diferenciada. Falta o apoio pedagógico para que essas coisas aconteçam, para } \\
\text { que novas práticas surjam na realidade do município. Para que isso seja realidade, } \\
\text { deve-se mudar a visão pedagógica e não só de cumprimento de dever, de obrigação } \\
\text { como vem sendo. Então, basicamente os problemas são vários. }\end{array}$ \\
\hline
\end{tabular}

Organização: Carvalho Sobrinho, 2016.

A elaboração da pergunta inicial dessa seção teve como objetivo identificar quais os conteúdos que os professores ministram, para posterior desencadeamento sobre a prática pedagógica. Entretanto, retomamos o debate do livro didático, por perceber que os conteúdos de ambos os professores basear, especificamente, neste instrumento pedagógico, isto é, o plano de ensino é o próprio livro didático.

O plano de ensino é feito baseado no mesmo conteúdo que é ministrado no livro, nós seguimos esse livro que é o nosso plano de ensino. Então, sigo os conteúdos na sequência do livro didático e assim vou trabalhando durante o ano (Professor A, 2016).

Voltamos a reiterar que o processo de ensinar/aprender Geografia na Educação Básica é realizado por instrumentos pedagógicos e que o livro didático é o principal recurso utilizado na mediação dos conhecimentos da disciplina (CARVALHO SOBRINHO; LEITE,2016). Assim, como afirma Tonini (2011), não podemos desconsiderar este instrumento, pois, todos os dias, nas mais distintas partes do mundo, os alunos entram em sala de aula portando livros didáticos.

Estas discussões e análises convergem para a crítica e debate acerca do livro didático, que deve se preocupar em aguçar no aluno as causas e as consequências dos fatos que são latentes no espaço geográfico e, além disso, inserir o seu lugar no processo de aprendizagem para que o aluno se reconheça como sujeito atuante no mundo. Todavia, o livro didático analisado a categoria em questão não se apresenta como mediadora dos conhecimentos geográficos, pois se apresenta de forma tímida e superficial.

Sabemos que dificilmente o Lugar/Formosa será considerado no livro didático, mas a mediação pedagógica em Geografia que pondere a categoria lugar deve ser conduzida pelo 
professor no sentido de articular o local ao global e vice-versa. Portanto, é muito importante que os professores ressignifiquem os conteúdos ministrados no sentido de reforçar a importância dessa categoria para o ensino de Geografia, no estabelecimento de relações com a totalidade e para a prática da cidadania crítica coletiva, e, desse modo, sejam capazes de estimular, criticar e participar na transformação dos seus espaços vividos, de forma ética e responsável.

Ao analisar como o professor A conduz esses conteúdos, percebeu-se que faz uso do livro didático, vídeos, textos complementares, grupos de discussão, trabalho de pesquisa, imagens, mapas, leitura do livro, globos, slides e quadro. Notou-se que tenta dinamizar a construção desses conteúdos, mas que, em nenhum momento, analisa esses conteúdos por meio da categoria lugar. Ou seja, a utilização desses recursos não garante a aprendizagem em Geografia de forma significativa, pois não problematiza por meio do cotidiano do aluno para estimular e agregar novos conceitos na sua estrutura de seus pensamentos (CASTELLAR; VILHENA, 2010). Esses elementos de mediação pedagógica só contribuirão de forma significativa com base em uma perspectiva dialógica, na qual os alunos podem construir conhecimentos. Nesse sentido, o lugar poderia assegurar a aprendizagem, mas sequer é considerado, pois, como foi detectado, não há uma preocupação em relacionar os conteúdos trabalhados com o cotidiano vivido dos alunos, como se pode observar no quadro 8 .

Neste caso, algumas indagações são pertinentes: mesmo se tratando de Geografias de outros continentes, não há possibilidade de relacionar com o lugar (cidade, estado, país ou continente) do aluno? Qual a relação desses conteúdos com a vivência dos alunos? Será que a cidade de Formosa - Goiás não permite a relação com tais conteúdos? Reiteramos que possibilidades existem, porque o mundo é globalizado, no qual as relações entre as escalas estão cada vez mais próximas. Como afirma Straforini (2008), as relações globais, em sua dimensão espacial, materializam-se no lugar por meio das variadas escalas. Portanto, os conteúdos poderiam ser mediados por meio da categoria lugar, mas isso dependeria da formação e disposição do professor para abordá-la e valorizá-la na construção dos conhecimentos geográficos.

Observa-se que o professor B tem uma dinâmica distinta de trabalho e afirma que: "os conteúdos do $9^{\circ}$ ano são conteúdos muito específicos, na verdade, são conteúdos, muita das vezes, bastante atuais se formos fazer um link com as relações que acontecem no mundo" (PROFESSOR B, 2016). Nesse sentido, utiliza vídeos, datashow, slides, livro didático, jornais, reportagens e filmes, para conduzir as temáticas, por meio da promoção de uma 
parceria pedagógica que, segundo ele, seria a utilização de recursos didáticos a seu favor. O problema que encontramos nesse argumento é que os professores entrevistados nessa pesquisa têm o hábito de dizer que a falta de instrumentos materiais impedem de fazer a mediação pedagógica, de tal maneira que se configura como um equívoco. A utilização de instrumentos pedagógicos, mesmo que contribua, não pressupõe a realização ou ocorrência desta mediação. O emprego destes recursos pode ser tão cansativo quanto uma aula de cunho tradicional, na qual o docente considera o estudante como um receptáculo de informações.

Foram percebidos muitos termos que indicam perspectivas da pedagogia tradicional nos argumentos do professor B,

Então, devemos mostrar para o aluno que o conteúdo é algo vivo, não é algo pronto e acabado, temos que fazer exercícios para absorver e fixar, isso é importante, mas, o que é ainda mais importante é levar ao aluno à compreensão desse espaço, porque considero que é o objetivo principal de qualquer abordagem geográfica (PROFESSOR B, 2016).

A concepção desse professor, no que se refere à abordagem geográfica, na análise do quadro 9, revelou que a categoria lugar é negligenciada em sua prática pedagógica, isto é, não a utiliza para construir os conhecimentos geográficos. Não foi detectado, em suas proposições, que há a consideração e incorporação de temáticas do lugar para relacionar com o conteúdo que ministra, não se percebe que é possível fazer essa relação local-global por meio de processos de mediação pedagógica na abordagem desses conteúdos.

A falta de compreensão pode estar relacionada à formação inicial e continuada, pois ninguém é capaz de ensinar aquilo que não aprendeu. E como destacam os próprios professores, não houve reflexões sobre a Geografia Escolar na formação inicial e não há formação continuada ofertada pela Secretaria Municipal de Educação:

Para falar a verdade, não me lembro de nenhuma disciplina específica para a parte da Geografia escolar, a não ser a parte de estágio, mas isso era mais um envolvimento externo dentro da academia. A abordagem da Geografia Escolar na minha graduação foi inexistente. E, além disso, não me identificava com as disciplinas que envolviam educação (PROFESSOR B, 2016).

Não tinha essa questão de fazer estudos mais aprofundados, com textos, com livros, com autores da Geografia Escolar. Seria importante para poder saber, estudar e vivenciar essa realidade, mas não tínhamos. O que tivemos foi mais essa questão da prática, de postura, de como lidar com relação aluno e 
professor, mas teoria mesmo que estudasse, que fizesse com que se compreendesse, analisasse e conseguisse ver essa realidade da Geografia Escolar com embasamento teórico, nós não tivemos, em aula nenhuma. Nem no início e nem no final do curso (PROFESSOR A, 2016).

Os docentes identificam, em suas práticas, três problemas principais, a saber: falta de recursos materiais, falta de pré-requisitos e indisciplina. Em relação ao primeiro, observa-se um antagonismo em suas respostas, pois atestam que utilizam recursos (datashow, vídeos, jornais, documentários, globos, mapas entre outros), mas alegam que a escola não dispõe destes. Nesse sentido, suas próprias palavras expõem a contradição. Nesse contexto, emerge um questionamento pertinente: a categoria lugar não seria um recurso de mediação pedagógica? Por que os professores negligenciam a sua utilização? Tais questões que nos levam a acreditar que os problemas identificados na prática pedagógica desses professores não estão ancorados somente na falta de recursos materiais, até porque os utilizam, mas principalmente, em sua dificuldade para compreender e promover análises dos conteúdos, por meio da categoria lugar. Nesse sentido, é conveniente ressaltar que esta categoria se constitui como uma ferramenta mediacional para a construção e reconstrução dos conhecimentos geográficos (LEITE, 2012).

Em relação ao segundo e terceiro problema: falta de pré-requisitos (falta de domínio mínimo dos conteúdos dos anos anteriores, essenciais à sistematização dos conhecimentos geográficos do respectivo ano) e a indisciplina, estes influem nas práticas pedagógicas dos professores ao trabalhar os conteúdos e os levam à desmotivação e, consequentemente, à defasagem o ensino da Geografia. Consideramos que ambos os problemas existem e persistem, mas o professor é um profissional que deve possuir habilidades e competências para promover estratégias pedagógicas com o intuito de suprir ou tentar resolver essa discrepância.

Apesar disso, por mais que tentem desenvolver um trabalho diferenciado, as ações e proposições docentes se apresentam tradicionais na medida em que não valorizam o sujeito e seu espaço vivido para a construção do saber geográfico. Se o aluno fosse inserido como um sujeito ativo nesse processo, sua motivação para o aprendizado seria diferente, pois suas experiências concretas teriam interligamento e coerência dentro do que é ensinado na escola (OLIVEIRA, 2015). Nesse sentido, por não se sentir inserido no processo pedagógico, a resposta do aluno será,de certo modo, a antipatia pela disciplina, gerando a falta de prérequisitos e indisciplina. 
Mesmo com todos estes problemas, consideramos que os professores não devem justificar a ineficácia do processo de ensinar/aprender Geografia mediante eles. Até mesmo porque é tarefa da escola em geral e do ensino de Geografia em particular garantir a aprendizagem de todos, indisciplinados ou não, com recursos materiais ou não, com prérequisitos ou não, com supostos problemas ou não (AQUINO, 1998).

Assim, no tocante ao ensino de Geografia, entendemos que é necessário que sejam promovidos momentos para que os alunos superem essa defasagem em busca da sistematização dos conhecimentos e, por meio da posse destes, reconheçam-se enquanto sujeitos "que têm direitos e deveres ao pertencer a uma sociedade, e nela os diversos grupos sociais que vivem num espaço que é construído cotidianamente a partir do trabalho" (CALLAI, 2000, p. 89), ou seja, são partícipes na construção da cidadania.

A categoria lugar seria, a nosso ver, uma alternativa na busca da superação desta problemática e contribuiria para a construção da cidadania dos alunos, devido ser na prática espacial cotidiana que o saber geográfico se sistematiza de forma mais prazerosa para o aluno, pois reconheceria que os conhecimentos fazem parte do seu cotidiano, mas que isso só tem como acontecer se o professor conseguir, por meio da mediação, construir conhecimentos significativos com esses alunos (CAVALCANTI, 2012).

Fizemos considerações acerca de algumas possibilidades afetas à utilização do Lugar/Formosa, como via de mediação pedagógica para construção de conceitos científicos em Geografia. Nesse contexto foram observadas temáticas que se referem aos conteúdos abordados nos livros didáticos do $9^{\circ}$ ano do Ensino Fundamental e que podem ser significados pela realidade dos alunos, isto é, existem alternativas viáveis no processo de mediação didática e pedagógica, associadas à construção do saber geográfico.

Entretanto, a inclusão do Lugar/Formosa no contexto das aulas de Geografia não é feita. Ele não é considerado nas práticas pedagógicas do professores pesquisados, isto é, não conferem significação aos conteúdos por meio do próprio lugar/cidade dos alunos. Ficou evidenciada a dificuldade dos docentes/entrevistados em compreender e promover a análise dos conteúdos com o uso desta categoria por não terem formação para trabalhar nesta perspectiva.

Ao relacionar algumas discussões que realizamos anteriormente acerca da categoria lugar e da construção da noção de cidadania, considera-se que repensar as concepções teóricometodológicas no ensino de Geografia significa refletir sobre o contexto atual da sociedade e 
sobre a necessidade de formação dos alunos para que saibam relacionar o seu espaço imediato de relações com outros que não os sejam imediatos, mas que contribuem para a formação cidadã para o século XXI. Infelizmente, há muito que avançar em termos de práticas pedagógicas em Geografia para que, de fato, os conhecimentos geográficos façam sentido na vida prática desses alunos e que impliquem no modo de ver, criticar e intervir na realidade. 


\section{CONSIDERAÇÕES FINAIS}

É inquestionável que o processo de ensinar/aprender Geografia, na contemporaneidade, se apresenta complexo. As práticas pedagógicas da disciplina devem ser adequadas à compreensão da atualidade, na qual deve ser considerada a dinâmica espacial, que impõe novas formas e funções no cotidiano dos indivíduos e, consequentemente, em sua relação com a totalidade.

Nesse contexto, esta pesquisa teve como objetivo investigar a prática pedagógica de dois professores de Geografia da cidade de Formosa - Goiás, para compreender se a categoria lugar é considerada na construção dos conhecimentos geográficos e se contribuiu para a construção da cidadania dos alunos.

Para isso, buscou-se fundamentação teórica referente à Geografia Escolar e nessa perspectiva, a utilização do lugar dos alunos como via de mediação pedagógica para a construção de conhecimentos em Geografia. Analisaram-se documentos importantes sobre a prática pedagógica dos professores - PPPs, PE e LD - que possibilitaram pensar o ensino de Geografia nas escolas pesquisadas. Além disso, a pesquisa empírica realizada identificou problemas, que se constituem obstáculos e perspectivas à construção da aprendizagem e da formação para a cidadania por meio dessa disciplina.

Evidenciou-se que o ensino de Geografia, na Educação Básica, tem função importante para a formação cidadã, isto é, formar sujeitos que consigam compreender a realidade marcada por contradições e, nesse contexto, agir no mundo no sentido de participar na construção de um lugar melhor, ou seja, do bairro, da sua cidade, do país, de forma responsável. Assim, considerou-se que a cidadania dos alunos deve partir de sua compreensão da realidade em que vivem e das relações que o mundo contemporâneo impõe sobre o seu lugar.

Os resultados obtidos atestaram que o processo de ensinar/aprender Geografia nas escolas pesquisadas em Formosa - Goiás negligenciaram a categoria lugar, como instância mediadora na construção dos conhecimentos geográficos, o que interfere de forma significativa na formação para a cidadania. O Lugar/Formosa, mesmo constituindo-se como ímpar ao processo de escolarização, por ser o espaço vivido dos alunos dessa cidade, não é considerado nessa perspectiva. 
As análises documentais atestaram que a categoria lugar é muito pouco utilizada, não se apresenta o como ponto de partida e/ou chegada na construção dos conhecimentos da disciplina. Os PPPs desconsideram o lugar e suas proposições se apresentaram de forma generalizante, sem fazer referência ao contexto vivido dos alunos. É imprescindível ressaltar que as expectativas de aprendizagem foram extraídas dos PCNs, sem nenhuma adaptação ao contexto no qual as escolas e alunos se inserem.

Consideramos prejudicial à inexistência dos PEs, porque as questões pedagógicas carecem de diálogo e de ressignificação aos contextos vivenciados pelos sujeitos. A ausência desse documento é danoso ao processo de ensino/aprendizagem em Geografia, pois referemse às ações de planejamento do professor em relação ao papel que desempenha na formação dos alunos. É por meio dele que o professor seleciona conteúdos e estratégias didáticopedagógicas, para construir conhecimentos com seus alunos. Em relação ao presente caso, o PE poderia ter considerado o contexto vivido pelos alunos e sua relação com a construção da aprendizagem em Geografia em seus diversos conteúdos e linguagens. Como os professores não os elaboraram, percebemos que há uma fragilização da mediação pedagógica.

O LD, de forma geral, evidencia pouca preocupação com a categoria em pauta, nem tampouco suas possibilidades de uso orientadas à aprendizagem do aluno. Contudo, deve-se ressaltar que o professor pode redimensionar e relacionar os conteúdos, tal como aplicá-los ao lugar, considerando-o elemento de mediação pedagógica orientado à sua significação, o que permitirá uma compreensão mais efetiva dos fenômenos geográficos por parte do aluno.

Contatou-se, ainda, que o planejamento da disciplina é realizado tendo como base no livro didático, em que, ao analisá-lo, percebemos que a abordagem do lugar se apresenta de forma tímida, fragmentada e superficial. Em nossa opinião, para que tenhamos uma formação e a valorização do espaço vivido pelo aluno e de sua formação enquanto sujeito e cidadão, novas pesquisas devem ser realizadas para verificar o potencial de uso da categoria lugar no LD e criticar a posição inferior que essa abordagem se encontra.

Pela análise das entrevistas, detectou-se que à categoria lugar não foi considerada como mediadora dos conhecimentos Geográficos no ano analisado. Em consequência, sua desconsideração na prática pedagógica significou a perda de uma excelente oportunidade de motivação aos estudos, pela inserção do espaço de vivência dos alunos, elemento mediador ao estabelecimento de parâmetros concretos para construção de conceitos geográficos e, por 
conseguinte, maior possibilidade de significação de conteúdos, que poderiam se desdobrar em práticas socioespaciais na própria localidade, o que atestaria o exercício da cidadania.

Percebe-se, dessa forma, que a categoria lugar pode mediar e contribuir para o alcance da cidadania, mas cabem aos professores, então, ressignificar e valorizar essa perspectiva no processo de aprendizagem. É necessário, mais do que nunca, refletir sobre as práticas pedagógicas em Geografia, para que se busque formação continuada, com o objetivo de subsidiar a construção de metodologias mais significativas, orientadas à construção de conhecimentos geográficos, necessários à formação para a cidadania dos alunos. Porém, se a formação continuada não ocorre e tampouco o professor se mobiliza para isso, dificilmente essa intenção será alcançada. E, em decorrência, um ensino tradicional tende a permanecer.

Compreende-se que ensino de Geografia pode, por meio da categoria lugar, ser conduzido numa perspectiva significativa, superando um ensino monótono, que unicamente descreve os fenômenos, sem estabelecer ligação com a vida cotidiana. A utilização dessa categoria visa suplantar uma concepção tradicional de ensino, para buscar relações dos conteúdos estudados com a realidade discente, elaborar explicações e atividades que façam pensar o seu lugar, em diferentes escalas, numa dinâmica de articulação da relação localglobal.

Nesse entendimento, é relevante reconhecer a complexidade de se pensar o fazer pedagógico por meio do lugar, por mais simples que pareça. Uma das dificuldades está na formação inicial e continuada, que tem sido realizada sem reflexão das categorias analíticas na compreensão dos fenômenos geográficos, no qual a categoria lugar se inclui. Esta pode ser uma das razões para o distanciamento do cotidiano. Assim, a prática pedagógica só poderá tornar-se efetivamente crítica e humanizante se conciliar com a realidade em que os sujeitos estão inseridos. Sendo assim, faz-se necessário o reconhecimento de que as práticas só se efetivarão se os docentes buscarem ampliar sua consciência sobre a importância da suas ações que pressupõem os conhecimentos teóricos e críticos sobre a própria realidade em transformação. Para isso, cada agente do processo educativo: aluno, professor, sociedade e Estado deve se comprometer com questões atinentes à educação em geral e à educação geográfica em particular. Esse último se exime da sua função, o que gera o desinteresse dos demais agentes.

Finalizamos com uma reflexão na qual Abade de Vallemont (Apud BACHELARD, 1978), diz que os caracóis constroem suas casas e as carregam consigo. Nesse sentido, estão 
sempre em sua casa, seja qual for o espaço em que estejam, estarão experimentando o seu mundo. Esta analogia nos faz pensar que a importância desse trabalho orientado à construção da aprendizagem em Geografia, por meio do mundo vivido na sua relação com a totalidade.

À guisa de conclusão, almejamos que tais reflexões possam ressignificar a implementação da prática pedagógica em Geografia na cidade de Formosa - GO. Esperamos que esta pesquisa possa contribuir para o desenvolvimento de outras, para reforçar a relevância do ensino de Geografia vinculado à realidade vivida pelo aluno. Trata-se de uma ação potencializadora, uma vez que se o aluno compreende a sua Geografia, as demais Geografias serão construídas por um melhor entendimento do mundo, mais significativo à formação do cidadão. 


\section{REFERÊNCIAS}

ALVES, G. A. Cidade, cotidiano e TV. In:CARLOS, A. F. A. (Org.). A Geografia na sala de aula. São Paulo: Contexto, 1999.

AQUINO, J. G. A indisciplina e a escola atual. Revista da Faculdade de Educação, v. 24, n. 2, p. 181-204, 1998.

ARRAIS, T. A. A produção do território goiano: economia, urbanização, metropolização. Goiânia: Editora UFG, 2011.

BAILLY, A. SCARIATI, R. L'humanisme en géographie. In: BAILLY, Antoine. Les concepts de la géographie humanine.Paris: Armand Colin,p.213-222, 2001.

BAUER, M.W. GASKELL, G. Pesquisa qualitativa com texto, imagem e som: um manual prático. Petrópolis: Vozes, 2002.

BENTO, I. P.. Estudar a cidade e seus sujeitos para aprender Geografia. In: MORAIS, Eliana Marta Barbosa de; CAVALCANTI, Lana de Souza (Orgs.). A cidade e seus sujeitos. Goiânia: Editora Vieira, 2011. p. 71-88.

BRASIL. Secretaria de Educação Fundamental. Parâmetros curriculares nacionais: terceiro e quarto ciclo do ensino fundamental: Geografia. Brasília: MEC/SEF, 2001.

Ministério da Integração Nacional; GOIÁS. Secretaria do Planejamento e

Desenvolvimento; FORMOSA, Prefeitura Municipal de (2003). Plano Diretor do Município de Formosa/GO: relatório final consolidado - revisão final. Disponível:

〈http://www2.seplan.go.gov.br/seplan/down/planodiretor/PD_Formosa.pdf >. Acesso em: 04 abr. 2016.

CACETE, N. H. Reforma Educacional em questão: os Parâmetros Curriculares Nacionais para o ensino de Geografia e a formação de professores para a escola básica. In:

ALBUQUERQUE, Maria Adailza Martins de; FERREIRA, Joseane Abílio de Sousa (Orgs). Formação, pesquisas e práticas docentes: reformas curriculares em questão. João Pessoa, Ed Mídia, p.47-58, 2013.

CALLAI, H. C. Geografia: um certo espaço, uma certa aprendizagem. Tese (Doutorado em Geografia) - Pós-Graduação em Geografia. São Paulo: USP, 1995.

O ensino de Geografia: recortes espaciais para análise.

In:CASTRIGIOVANNI, A. C. et al (Orgs.). Geografia em sala de aula: práticas e reflexões. Porto Alegre: Ed. da Universidade, p. 56-60, 1999.

Estudar o lugar para compreender o mundo. In: CASTROGIOVANNI, A. C.

(Org.). Ensino de Geografia: práticas e textualizações no cotidiano. Porto Alegre: Mediação, p. 72-112, 2000.

128-139, 2011.

A Geografia escolar - e os conteúdos da Geografia. Anekumene, v. 1, n. 1, p. 
CARLOS, A. F. A. O espaço urbano: novos escritos sobre a cidade. Ed. Contexto, 2004.

O lugar no/ do mundo. São Paulo: Labur Edições, 2007.

Cidade. São Paulo: Contexto, 2013.

CARVALHO SOBRINHO, H. A categoria lugar no livro didático de Geografia:

abordagens e contribuições no processo de ensino/aprendizagem. 2014. 144 p. Monografia

(Graduação em Geografia) - Câmpus Formosa, Universidade Estadual de Goiás, Formosa, GO, 2014.

CARVALHO SOBRINHO, H. SUESS, R. C. Parâmetros Curriculares Nacionais para o ensino de Geografia ( $3^{\circ}$ e $4^{\circ}$ ciclo): uma abordagem crítico-reflexiva. Revista Querubim, v. 1, p. 100-106, 2014.

CARVALHO SOBRINHO, H. LEITE, C. M. C. Geografia Escolar e o lugar: construção de um processo de ensino/aprendizagem significativo. Presidente Prudente: Enapege, 2015.

A categoria lugar na construção de significados no ensino de Geografia:

alguns pressupostos. Revista Querubim, n. 30, v. 2, p. 112-118, 2016.

Abordagem do lugar no livro didático de Geografia do $6^{\circ}$ ano do Ensino

Fundamental. Revista Cerrados, n.2, v. 14, p. 125-140, 2016.

CASTELLAR, S. M. V. Educação Geográfica: Formação e didática. In: MORAIS, E. M. B.; MORAES, L. B. (Orgs.). Formação de professores: conteúdos e metodologias no ensino de Geografia. Goiânia: Nepeg, 2010.

. "Lugar de Vivência: a cidade e a aprendizagem". In: Garrido, Marcelo.

(Org.). Reflexiones sobre eles pacioenel mundo educativo. Reflexiones sobre el espacioenel mundo educativo. 1ed. Santiago: Ediciones Universidad Academia de Humanismo Cristiano, 2009, p. 37-56.

CASTELLAR, S. M. V.. VILHENA, J. Ensino de Geografia. Cengage Learning, 2010.

CAVALCANTI, L. S. Geografia e práticas de ensino. Goiânia: Alternativa, 2002.

- A Geografia escolar e a cidade: Ensaios de Geografia para a vida urbana cotidiana. Campinas, SP: Papirus, 2008.

. O ensino de Geografia na escola. Campinas, SP: Papirus, 2012.

CORRÊA, R. L. Espaço: um conceito-chave da Geografia. In: CASTRO, Iná Elias de;

GOMES, Paulo Cesar da; CORREAA, Roberto Lobato (orgs.). Geografia: conceitos e temas. Rio de Janeiro: Bertrand Brasil, p. 15-47, 2001.

DAMIANI, A. L. A Geografia e a construção da cidadania. In: CARLOS, Ana Fani. A.

(Org.). A Geografia na sala de aula. São Paulo: Contexto, 1999. p. 50-61. 
DARDEL, E. O homem e a terra: natureza da realidade geográfica; tradução Werther Holzer. - São Paulo: Perspectiva, 2011.

DEBORD, G. A sociedade do espetáculo: comentários sobre a sociedade do espetáculo. Rio de Janeiro: Contraponto, 1997.

FERREIRA, L. F. Acepções recentes do conceito de lugar e sua importância para o mundo contemporâneo. Território. Rio de Janeiro, ano 5, n. 9, p. 65-83, jul./dez., 2000.

FORMOSA, Município de. Secretaria Municipal de Educação. Escola A. Projeto políticopedagógico. Formosa: Secretaria de Educação, 2016.

Secretaria Municipal de Educação. Escola B. Projeto político-pedagógico. Formosa: Secretaria de Educação, 2016.

GIDDENS, A. As consequências da modernidade. São Paulo: Editora UNESP, 1991.

HARVEY, D. A Condição Pós-Moderna. São Paulo: ed. Loyola, 1992.

INSTITUTO DE BRASILEIRO DE GEOGRAFIA E ESTATÍSTICA - IBGE.Goiás;

Formosa. Disponível: 〈http://cidades.ibge.gov.br/xtras/perfil.php?codmun=520800>. Acesso em: 08 de março. 2016.

INSTITUTO NACIONAL DE ESTUDOS E PESQUISAS EDUCACIONAIS - INEP. Censo Educacional 2013. Brasília: INEP/MEC, 2013.

LEFEBVRE, H. O direito à cidade. Tradução de Rubens Eduardo Frias. São Paulo: Editora Moraes, 1991.

LEITE, C. M. C. “Geografia no Ensino Fundamental” In: Universidade/Departamento de Geografia. Espaço e Geografia (UnB), v. 5, p. 245-280, 2002.

O lugar e a construção da identidade: os significados construídos por professor de Geografia do ensino fundamental. 222 f., 2012. Tese (doutorado em Geografia). Faculdade de Educação, Programa de pós-graduação em Educação, Universidade de Brasília, 2012.

LEITE, C. M. C. BARBATO, S. B. Reflexões sobre o conceito de lugar na escola contemporânea. Espaço e Geografia, v. 14, p. 225-255, 2011.

LIBÂNEO, J. C. Didática, São Paulo: Cortez. 1994.

LÜDKE, M. ANDRÉ, M. E. D. A. Pesquisa em educação: abordagens qualitativas. São Paulo: EPU, 2013.

MACÊDO, H. C. REFLETINDO SOBRE O ESPAÇO VIVIDO: o lugar na construção dos conhecimentos geográficos. Revista Brasileira de Educação em Geografia, v. 5, n. 10, p. 152-165, 2016.

MAGALHÃES, L. R. ELEUTÉRIO, R. Estrada Geral do Sertão - na rota das nascentes. Brasília: Terra Mater Brasilis, 2008. 
MARANDOLA JR, E.; HOLZER, W.; OLIVEIRA, L. (orgs.).Qual espaço do lugar? Geografia, epistemologia, fenomenologia. São Paulo: Perspectiva, 2012.

MONTI, E. R. As veredas do grande sertão- Brasília. Ocupação, Urbanização e Resistência Cultural. Tese de Doutorado Brasília - D.F, maio/2007. 308 p.

OLIVEIRA, S. R. F. O que fomos, o que somos e o que queremos ser: uma reflexão sobre a docência. História ; Ensino, v. 11, p. 63-73, 2012.

OLIVEIRA, L. O ensino/aprendizagem de Geografia nos diferentes níveis de ensino. In: PONTUSCHKA, Nídia Nacib; OLIVEIRA, Ariovaldo Umbelino de. Geografia em perspectiva: ensino e pesquisa. São Paulo: Contexto, 2015.

PHILLIPS, B. S. Pesquisa Social. Rio de Janeiro: Agir, 1974.

PONTUSCHKA, N. N.; PAGANELli, T. I; CACETE, N. H. Para Ensinar e Aprender Geografia. São Paulo: Ed. Cortez, 2007.

PROFESSOR A. Escola A. Formosa, 2016. Entrevista realizada nos meses de Maio, Julho e Agosto, 2016.

PROFESSOR B. Escola B. Formosa, 2016 Entrevista realizada nos meses de Maio, Julho e Agosto, 2016.

PROGRAMA DAS NAÇÕES UNIDAS PARA O DESENVOLVIMENTO - PNUD (2013). Ranking IDHM Municípios 2010. Disponível em:

<http://www.pnud.org.br/atlas/ranking/Ranking-IDHM-Municipios-2010.aspx>. Acesso em: 08 Maio. 2016.

RELPH, E. Place and placelessness. London: Pion, 1976.

RICHARDSON, R. J. et al. Pesquisa Social: métodos e técnicas. São Paulo: Atlas, 2014.

SANTOS, M. A natureza do espaço: técnica e tempo, razão e emoção. São Paulo: Hucitec, 1996.

O espaço do cidadão. 5 ed. São Paulo: Studio Nobel, 2000.

Da Totalidade ao Lugar. São Paulo: EDUSP, 2008.

Por uma outra globalização: do pensamento único à consciência universal.

São Paulo: BestBolso, 2009.

SCARLATO, F. C. População e urbanização brasileira. In: ROSS, R. L. S. Geografia do Brasil. São Paulo: Edusp, p. 381 - 463, 2011.

SILVA, A. B. A Geografia do espaço escolar: jovem-aluno, práticas espaciais e aprendizagem geográfica. 2016. 238 f. Tese (Doutorado em Geografia) - Instituto de Estudos Socioambientais, Universidade Federal de Goiás, Goiânia, 2016. 
SILVA, A. S. Espaço urbano, desigualdade e indicadores de dimensões de sustentabilidade: análise de Formosa-GO. 2011. 277 f. Tese (Doutorado em Geografia), Universidade Estadual Paulista "Júlio de Mesquita Filho", Presidente Prudente, 2011.

SOUZA. F. E. As "geografias" das escolas no campo do município de Goiás: instrumento na valorização do território do camponês? São Paulo: UNESP, 2012. Tese (Doutorado) Programa de Pós - Graduação em Geografia, Universidade Estadual Paulista, São Paulo, 2012.

SPOSITO, E. S. A vida nas cidades. São Paulo: Contexto, 2013, 90 p.

STRAFORINI, R. Ensinar Geografia: o desafio da totalidade-mundo nas séries iniciais. Annablume, 2008.

TONINI, I. M.. O ensino de Geografia e suas composições curriculares: Livro Didático: textualidades em rede?Porto Alegre: Ufrgs, 2011, 180p.

TUAN, Yi-Fu. Espaço e Lugar: a perspectiva da experiência. Tradução de Lívia de Oliveira. Londrina, PR: Eduel, 2013.

p. 4-15, Inverno 2011.

Espaço, tempo, lugar: um arcabouço humanista. Geograficidade, v. 01, n. 01, Topofilia: um estudo da percepção, atitudes e valores do meio ambiente.

Londrina, PR: Eduel, 2012.

VERGARA, S. C. Métodos de coleta de dados no campo. Atlas, 2009.

VIEIRA, G. J. Formosa, Cidade e Povo. Brasília: ed. 2, 2010. 
APÊNDICES 
APÊNDICE A - Roteiro para caracterização das escolas pesquisadas
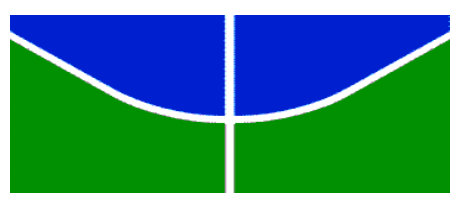

UNIVERSIDADE DE BRASÍLIA

INSTITUTO DE CIÊNCIAS HUMANAS

PROGRAMA DE PÓS-GRADUAÇÃO EM GEOGRAFIA

Pesquisa: A CATEGORIA LUGAR NA CONSTRUÇÃO DOS CONHECIMENTOS

GEOGRÁFICOS: análise a partir da prática pedagógica do professor de Geografia em Formosa-Goiás

Pesquisador: Hugo de Carvalho Sobrinho

Orientadora: $\mathrm{Dr}^{\mathrm{a}}$ Cristina Maria Costa Leite

Roteiro para caracterização das escolas pesquisadas

Data da visita

Nome da escola:

Histórico do surgimento da escola:

Números de alunos matriculados: 
Números de alunos matriculados e frequentes no $9^{\circ}$ ano do Ensino Fundamental por sexo:

Masculino

Feminino

Séries que são ofertadas:

Números de servidores (Cargo/Quantitativo):

- Administrativos

- Serviços gerais

- Professores

- Merendeiras

- Outros

Quantidade de salas

Quantidade de Banheiros:

Sala de professores, coordenação, direção, secretaria, entre outros:

\section{Outras observações}


APÊNDICE B: Roteiro de entrevista semiestruturada com os professores de Geografia

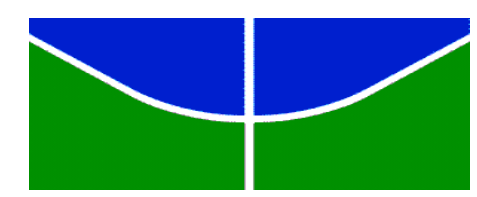

UNIVERSIDADE DE BRASÍLIA

INSTITUTO DE CIÊNCIAS HUMANAS

PROGRAMA DE PÓS-GRADUAÇÃO EM GEOGRAFIA

Pesquisa: A CATEGORIA LUGAR NA CONSTRUÇÃO DOS CONHECIMENTOS

GEOGRÁFICOS: análise a partir da prática pedagógica do professor de Geografia em

Formosa-Goiás

\section{Pesquisador: Hugo de Carvalho Sobrinho}

Orientadora: Dr ${ }^{\mathrm{a}}$ Cristina Maria Costa Leite

Data da entrevista ___

1 - Você poderia fazer sua apresentação como professor de Geografia? (Primeiro encontro)

- Qual o motivo que fez você optar pelo curso de Geografia;

- Qual eram as disciplinas preferidas no curso de Graduação;

- Conte um pouco da sua experiência como professor de Geografia na cidade de Formosa;

- Quais as principais dificuldades encontradas no exercício do seu magistério;

2 - Em relação à educação Geográfica (Segundo encontro)

- Qual a importância que você atribui ao ensino de Geografia?

- Como você avalia a situação do ensino da Geografia no Brasil e em Formosa hoje?

- Como você trabalha as aulas de Geografia? Especificar.

- Quais são os problemas que você identifica na sua prática pedagógica?

3 - Em relação ao conteúdo ministrado no $9^{\circ}$ ano do Ensino Fundamental (Terceiro encontro)

- Quais são os conteúdos de Geografia do $9^{\circ}$ ano? 
- Como você trabalha esses conteúdos de Geografia? Especificar.

- Quais são os problemas que você identifica na sua prática pedagógica ao trabalhar esses conteúdos? 
ANEXOS 


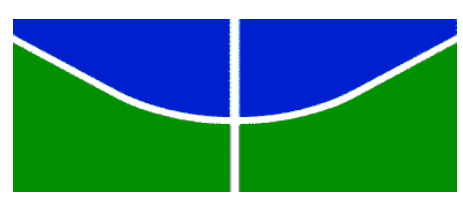 \\ UNIVERSIDADE DE BRASÍLIA \\ INSTITUTO DE CIÊNCIAS HUMANAS \\ PROGRAMA DE PÓS-GRADUAÇÃO EM GEOGRAFIA
}

\section{Pesquisa referente à Geografia Escolar}

\author{
Pesquisador: Hugo de Carvalho Sobrinho \\ Orientadora: Dr ${ }^{\mathrm{a}}$ Cristina Maria Costa Leite
}

Caro professor (a), gostaríamos de confirmar a sua participação na pesquisa em nível de Mestrado Acadêmico em Geografia da Universidade de Brasília. Assim, em respeito à Resolução No 466, de 12 dezembro de 2012 do CNS, a qual trata dos procedimentos éticos da realização de pesquisa com seres humanos, ressaltamos que os dados e informações obtidas serão utilizadas exclusivamente para fins acadêmicos.

A pesquisa demandará os seguintes procedimentos metodológicos: ENTREVISTAS E PESQUISA DOCUMENTAL (Projeto Político Pedagógico, Plano de Ensino e Livro Didático).

Solicitamos que assine no espaço abaixo, caso aceite participar deste trabalho de pesquisa.

Agradecemos a sua participação.

Assinatura do Professor

Assinatura do Pesquisador

Assinatura do Orientador 